

\section{University of California.}

FROM 'TIE, I.IBKARY' OF

I) R. FRANCIS L I E B L R,

Prifessor of History and Law in Columbia College, New Yurk.

THE: fillt ol:

MICHAEL REESE,

()f San livanitiso.

$1-7: 3$. 
Digitized by the Internet Archive in 2007 with funding from Microsoft Corporation 
111 
PHILOSOPHIC THEOLOGY. 
Francis Zieber L.L. 8 .

$$
\begin{aligned}
& \text { wit th affect.. Respect } \\
& \text { \& Estesm }
\end{aligned}
$$

\section{PHILOSOPHIC THEOLOGY; \\ OR,

ULTIMATE GROUNDS OF ALL

RELIGIOUS BELIEF BASED IN REASON.

BY

J A IES W. MILES.

CHARLESTON :

JOIIN RUSSELL, 256 KING-STREET.

NEW - Y ORK :

GEO. P. PUTNAM, 155 FROADWAY.

1849 . 
Entered according to the Act of Congress, in the year 1849, by J O H R U S E L L,

In the Clerk's Office of the District of South-Carolina.

,

CHA RLESTON:

WALKER AND JAMES, PRINTERS.

101 East-Bay. 


\section{ADVERTISEMENT.}

No REALly thoughtful and earnest spirited man can have avoided, at some time in his life, reflecting with deep interest upon the problems of his destiny and the universe, and forming some notions with regard to religion. The fruit of such meditations I now give to the world, because I believe that they will meet with some sympathy from those who have undergone similar mental processes, and that they may aid some in shaping their meditations into a definite form.

All pretence to dogmatize or demonstrate is anxiously disclaimed. It is the spirit of dogmatism in religion, repressing free inquiry, and forcing investigation into fixed and narrow channels, which has, more than almost any thing else, tended to beget and foster infidelity. The theologian too often makes magnanimous invitations to the fullest investigation and inquiry,-but decries and would suppress it the moment that it diverges from his own foregone conclusions. He has received christianity, or some modification of it, upon grounds satisfactory to himself; and forgetting that they may not prove equally convincing to differently constituted minds, he starts in pious horror from what he considers any rebellion against Divine Authority, without reflecting that that authority itself must be established upon something more than his bare assertion that God has thus spoken, and often too upon a vast deal more than has sufficed to satisfy himself. The main design, however, of these pages is rather to indicate lines of thought, which the serious and earnest mind may 
develope and make valid for itself. They have sprung from the necessity, which the mind of the writer has felt, for rendering to itself a sufficient reason for its convictions respecting religious belief, upon grounds of certainty, beyond the ordinary sphere of controversy. It is unavoidable that there should be similarity in the thoughts thoughts and conclusions of many minds employed upon these topics; and, therefore, I state at the outset, that my conclusions were arrived at independently of direct reference to any other person's labors on the same subject; but that truth, and not originality, being my aim, I have not hesitated to profit by those writings which set forth similar views, and which have come into my hands since commencing to commit the result of my reflections to writing-or rather to arrange in a form suitable for publication, the manuscript materials which had irregularly accumulated from those reflections. Among such writings as I have referred to, I mention particularly those of Mr. Morrell, the perusal of which is earnestly recommended to all who wish to see most of the topics discussed in this book, handled with great ability and masterly logic. 


\section{TO THE REA DER.}

THE object of this volume, is to suggest the Philosophic grounds involved in the chief points of Christian Theology. By Christian Theology, we understand the general truths respecting God and his relation to man, which Christianity bases in the principles of Reason, as distinguished from Divinity, or the formal system of dogmatic doctrines, deduced by the logical interpretation of Scripture.

Any writing in this latter sphere, belongs to particular Christian communities; but the points involved in the former, belong to the metaphysical philosopher, no less than to the technical divine; and, indeed, without a firm basis being laid in the former, there can be no truly Scientific Divinity.

That many are content to believe merely upon hereditary or traditive grounds, and that many actually do believe Christianity upon no ground, but their having been led through the subjective phase of "conversion," with no reference to historical or philosophical grounds, does not, in the least, render less necessary a valid and philosophical and rational account, of how the great doctrines of Christianity can approve themselves to the universal reason and consciousness of humanity.

Now, there are three great phases of Christian belief, existing as psychological facts; namely, that which believes primarily from internal conviction, without reference to any historical evidences, but upon the experience believed to be inwrought by the Holy Spirit; 
that which (whether attributing much or nothing to such experience,) rests upon what is regarded as valid traditional authority, declaring the one faith which must be received; and that which feels a difficulty in believing any system of Christianity, except one which rests upon grounds conceived to satisfy the exigencies of enlightened reason and science. Any attempt, therefore, to present a truly Philosophical Theology, must take into account the elements involved in these three phases of Christian belief; whatever value be assigned to them respectively, or however they may be treated. So far as we have touched upon those elements, will appear throughout the following work; but it should be borne in mind, that our whole discussion is prophylactic-warding off objections, rather than undertaking to demonstrate doctrines.

If Christianity be true at all, in the sense of a real divine revelation, it is of infinite moment. If it is not a mere natural product of the development of humanity, but if it springs from, and embodies ideas introduced immediately by, Deity himself, it must not only be consonant with reason, but it must possess imperative claims upon men; and there must be some means of arriving at absolute truth upon the subject. The salvation of men can not be awfully involved in a system, whose truth, as divine revelation, can never amount to more than a bare probability. There must, therefore, be some ground of certitude in the matter, or Christianity fails to fulfil the necessary conditions of an imperative revelation.

But it can not be denied, that the divisions and hostility within the pale of Christianity itself, and the rigid forms into which the truths of Christianity are thrown, in the opposing systems of different Christian bodies, both repel many earnest minds from a just and candid investigation of the subject, and also leare them even scep- 
tical as to whether any absolute truth in the matter is to be arrived at at all. Now, it may be said to this, that a man can not arrive at this absolute truth, until he has been "converted" by "the grace of God." But, not to discuss this point, we would simply ask in reply, whether, therefore, a man is to wait, in utter neglect of the whole question,--until he shall have been thus "converted," and, if not, whether Christians are not bound to meet his difficulties, and establish the fact of the reasonableness of their religion, and of its resting upon attainable and appreciable grounds of certainty.

The extraordinary phenomenon which Christianity presents in the history of man,- the influence which it exerts in the world,- the vitality it exhibits in the perpetual discussions which it calls forth,the cravings of earnest minds, who feel that man has a higher and nobler destiny than this ephemeral existence, which make them long: for some adequate solution of the vast mysteries which envelope their being,-all assure us that, in the attempt we make in these pages, we are meeting, in however feeble a degree, one current of the thought of the age. And, if we can show, despite the perplexing contrarieties of different systems, that Christian truth rests upon valid grounds of reason and certainty, we shall surely hare done something towards obviating objections, which repel certain minds from any acceptance of Christianity whatever.

We have no right to ask an earnest minded and honest lorer of the truth, to embrace our conclusions, without endeavoring to show that they are based in solid reason. Truth, too, while ever one, needs constantly to be re-produced in various forms; since arguments and appeals which are valid to one age, or mind, entirely fail in conveying conviction to another. The grounds of belief require to be perpetually re-stated and rëargued; and, while in this age of un- 
paralleled mental activity, when the first principles of every thing are subjected to the most inquisitive and critical analysis, it is necessary to establish truth by a course of rigid argument and indisputable evidence against its impugners, which may not be necessary for those who already believe; yet, with every man in whom breathes any nobility of nature, truth must be the deepest and loftiest aspiration of his soul; and, in proportion to his longing for, and estimate of the value of truth, will be his desire that his convictions should be based upon the broadest and deepest foundations of reason.

It would be the height of presumption and ignorance, to suppose that the course of argument which it is our design to suggest, will carry conviction to every one. For, if there is any one, who, in the present day, is not alive to the momentousness of the query, "what is truth ?' or who can be indifferent to the absorbing interest which attaches to the questions we shall discuss, our words are not for him. There must exist some sympathy between a writer and his readers, or his arguments will seem pointless, and his appeals mere declamation. But, reader, if you regard truth as the worthiest and noblest object of life, and truth, upon points which affect our religious belief, as the highest and most solemn, as it is certainly the most momentous, of all pursuits which can possibly demand our energies; then, these pages are humbly submitted to your consideration, in the belief that should you differ from the conclusions to which they would lead, yet the earnest desire for truth, and the sincere determinaiion to accept and act upon it when found, will bring us, in the end, nearer together in our course towards a common goal. 


\title{
CONTENTS.
}

\author{
P A R T I .
}

LETTERS BETWEEN A SCEPTIC AND HIS FRIEND.

Letter I-Letter from a Sceptic to his Friend, Page.

« II.-Reply to the preceding, - - - - $\quad$ - 8

“ III.-Another Letter from the Sceptic, - - 22

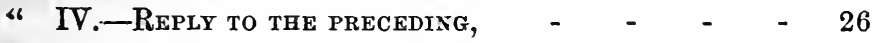

“ V.-ANother Letter from the Sceptic, - - 38

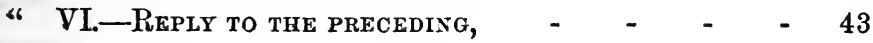

\section{P A R T I I.}

A DISCUSSION OF SUNDRY POINTS PERTAINING TO THEOLOGY.

Introduction.-The Possibility and Natere of Theology, 4

Chapter I.-The Idea of God as a Necessary Conception of Reason, and the Necessity of Max's Theological and Religious Conceptions, - - 73

" II.-Basis in the Necessary Conceptions of Reason for Belief in Incarnation, - - - $\quad 93$ 
xii. CONTENTS.

Chapter III.-The Grounds of the Probability of MiraCLES, AND THE SUGGESTIVE BASIS IN REASON FOR BELIEF IN PLURALITY IN DiviNe PERSONALITY, - 115

“ IV.-Analysis of Life and Character of Christ, 136

“ V.-Adaptedness of Christianity to the Religious WANTS of Man, - $\quad$ - $\quad$ - $\quad$ - $\quad$ - 158

“ VI.-The Organ of Religious Fatth, - - 175

" VII.-The Scriptures, - $\quad$ - $\quad-\quad$ - $\quad-193$

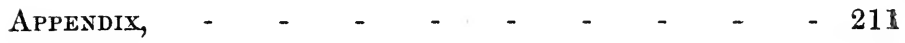

\section{CORRECTION.}

Owing to an inadvertency on the part of the author, the reader is desired to substitute for the first seven lines of Letter III, p. 22, the following:-

* * * "It is in no spirit of captiousness or levity that I doubt. I desire a view of religious truth, which my reason can approve; and your letter has afforded me satisfaction, because," \&c. \&c. 


\section{P A R T I.}

\section{LETTERS}

BETWEEN A SCEPTIC AND HIS FRIEND. 


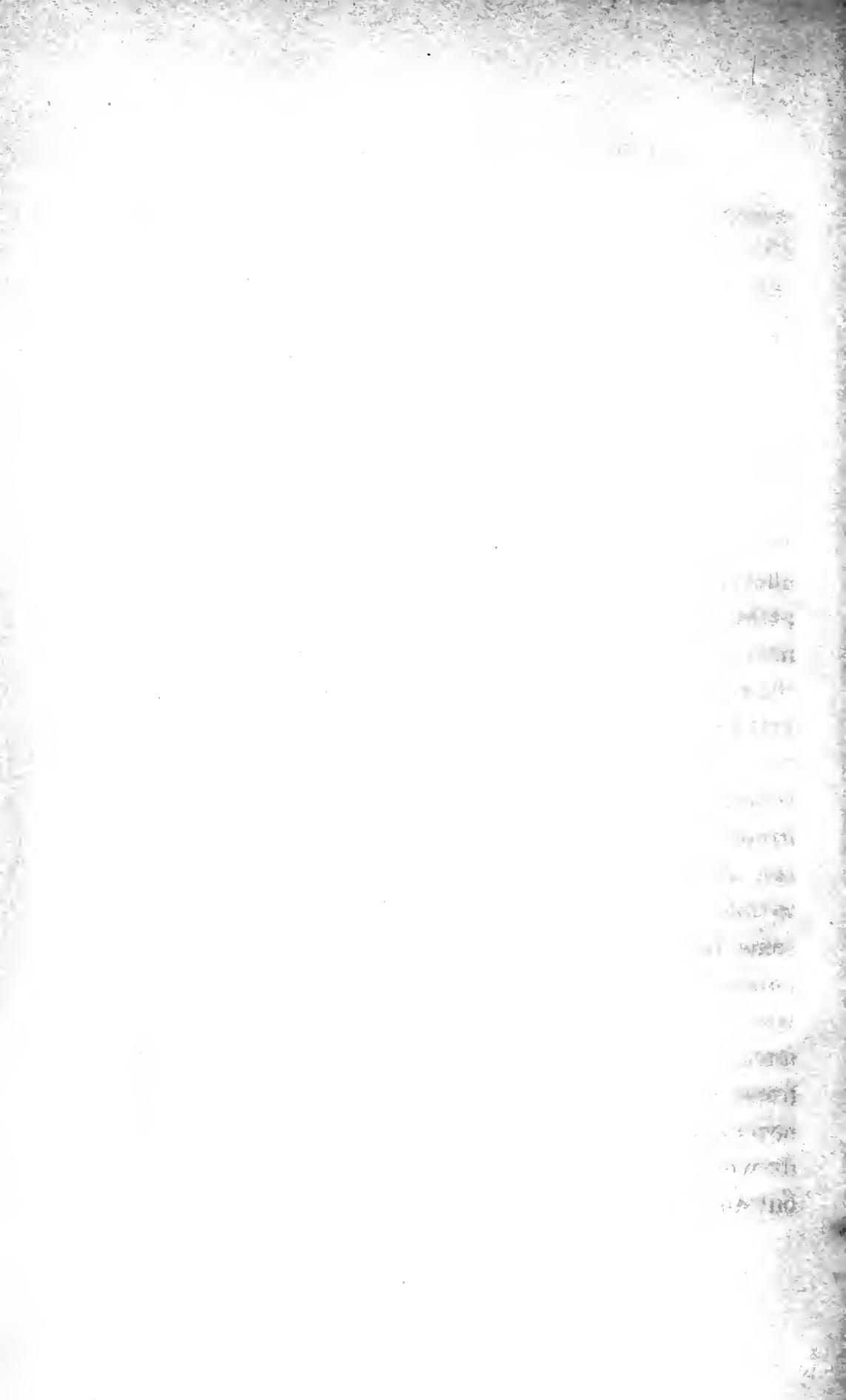




\section{LET TER I.}

LETTER FROM A SCEPTIC TO HIS FRIEND.

* * * A DEEP despondency oppresses my spirits, for which I scarcely know how to account; but I will seek to alleviate it by this distant converse with you, whose sympathy never fails, even when your well-balanced judgment must pronounce me wayward and unreasonable. And yet there is a cause for my depression, although I know that you will not allow it to be well founded, when brought to the test of that severe reason by which you so calmly regulate your whole being. But why are such deep and irrepressible yearnings implanted in our nature, if they can meet with no satisfaction? Are we forever destined to interrogate our own souls and all nature in vain, for some reply to the mysteries which seem to grow more impenetrable, the more we reflect upon them, and of which, reflection only makes us more imperatively demand some solution? Tell me, is it possible that this vast frame of the universe is only an eternal riddle, which can never disclose the secret of its own existence? Are all of its wonderful processes-(evolutions of manifest law, but an eternal succession of finite links, - an infinite fini- 
tude; an unchangeable fluctuation; a mighty and endless contradiction? Or what is the fixed, the everlasting, the absolute, the substance, beneath the ever flowing phenomena? Is there no substantial reality; is all an eternal nothing;-or does the law imply a lawgiver, the phenomena a substance, the changing finite, an absolute infinite? Is there no resolution of these paradoxes? And what can be said to the deeper mysteries of our own souls? Are we but shadowy phenomena like the rest, struggling through the dream of life, and swallowed up in the vast nothing, the universal show? Or is there any ground for our immortal aspirations; have our noblest ideas of the good, the beautiful, the true, no absolute basis, no perfect realization, no essential being? Is there no eternal reason; are all the indestructible convictions of humanity, a baseless self delusion? Is there no everlasting, unchangeable right, and no corresponding moral being to whom it stands in relation? Are all the mighty hopes and fears which cluster around death, and the overwhelming ideas of futurity and eternity, but empty phantoms? Are the sublimest incitements to duty, fortitude, endurance, virtue, religion, but dreamy figments ? Whence came all these grand ideas, imbuing humanity, and yet beyond its grasp; elevating reason, and yet above her most comprehensive range? Can it be possible that they all are but projected shadows of the imagination, evolutions of the laws of intellect, and not etcrnally rooted in a primal author, an all-sustaining power? 
And what too, can be said to those still deeper spiritual mysteries, will, personality? Can these have merely grown from the eternal evolutions of nature, and have no original in an absolute spirit? Can the blind law of nature originate such mysterious attributes, and possess itself no self consciousness? With an indestructible personal identity and conviction of moral choice, and with a mighty instinct which looks for God and immortality, must we lose ourselves, become nothing, so soon as we shall have passed from this unsatisfying existence? What is the origin of cause; the substratum of all; that which Is, beneath the unstable, ever-changing, ever-perishing phenomenal? Why do we ever find ourselves driven by the necessities of our own reason, to seek something absolute, original, ultimate, upon which to rest? And why does the grand rhythm of nature, and our own moral emotions, and may I not add our intellectual instincts, impel us to believe in, to worship, a Supreme existence, the causa causarum, the ens entium, the God of Nature, the Father of Spirits? Can we attain no ground of certainty for belief in God; or is the last, the loftiest reach of reason, but the indefinite propositions, that the universe exists-we know not how; that there is apparent a mighty vitality working under the manifestations of nature,-we know not what it is; that this hidden power is evidently law, whence, we can not tell, everlasting perhaps, and from eternity developing itself in the ever fluctuating cycles of phenomena, that we are among its highest manifesta- 
tions, and like all things else, must be resolved, at last, into the boundless impersonality of nature; or that perchance there is a self-conscious Being, God, who sustains and is the author of all, but of whom we can know nothing, unless perhaps in another life; who by an eternal necessity of his own nature has ever manifested himself in a universe, which is then as it were his own eternal body, his everlasting shadow, as necessary as himself; that every thing then, proceeds from a necessary law of the nature and development of God, and can not be otherwise, and that we can be certain neither of immortality nor annihilation? Is this the insuperable barrier to our knowledge and hopes; the end of religion and morals? Is this the goal of all philosophy? I will not speak of the terrible consequences of these propositions; it is vain to argue against a position from consequences, unless they can be shown to contradict some positively established fact. But here the question is as to all religion and morality. If those propositions embrace the compass of what we can know respecting God and futurity; blasphemy and impiety become impossible. If atheism or pantheism be true, it is absurd to argue against them because of consequences; if they can be demonstrated, we must accept them, even at the cost of losing the dearest consolations and hopes. But, at least, it may well cause doubt as to the soundness of principles, which, if established in the minds of men, would shake the foundation of all law, all social confidence, all common morality, and tend to plunge the world into the devouring 
anarchy of intense selfishness. But I know what can be replied to this; it can be said, that by the necessity which binds all things, men will ever be superstitious, the mass will never be enlightened, only the few nobler spirits will know the truth, and that social society, religion, morality, the restraints of law and conscience, are all included in the law of necessity, and therefore can never cease to be manifested and to rule among men. Let alone, then, consequences; it is time enough to discuss them when premises are settled; and come to my aid; give me an answer to my queries; I am lost in doubt, perplexity, confusion, when I meditate upon them; but tell me, if any answer can be found or hoped for. 


\section{LETTER II.}

REPLY TO THE PRECEDING.

* * * I CERTainly admit that there is a sufficient cause for your depression of spirits; but I think that you should not permit it to weigh upon you, merely because you can not fathom the mysteries, to which you so earnestly demand an answer. Those great problems must press upon every true thinker; that is, every one who takes not up opinions upon mere education, or authority, or any ground, in short, not based in philosophy. But as there must be a limit to our knowledge, from the very fact of our being finite, the true philosopher will rest as placidly and contentedly before a barrier to his progress, the moment he is satisfied that from the very finitude of his faculties, it really is an impassible limit; as he will rest upon a conquest of some attainable truth. As long as we believe truth attainable in the direction towards which we are pressing, we must feel unsatisfied and desponding, while it eludes our grasp; but the moment we become persuaded that we have reached the limit beyond which our efforts must be fruitless from the very necessities of 
our faculties, we can rest contented with what is possible. Nothing, however, is more difficult than persuading men that the limit is reached, or that there actually is a sphere, beyond which human reason can make no progress. Unfortunately, the very cloudiness and uncertainty which overhang that sphere, tempt men to speculate upon what it contains, and to maintain their speculations as true, with a dogmatism in proportion to the impossibility of knowing anything about the matter. There is also a great readiness on the part of men to affirm that those who differ from their own speculations, are transcending the limits of human knowledge, and venturing upon the sphere closed to certainty; while it is difficult for them to believe that they themselves can be limited by anything short of the most complete and definite information. So great, also, is the desire of men for certainty, and for what to them seems comprehensible fact, that they would rather receive and believe in some absurd but definite dogma, than own a truth to be irreducible by finite faculties to a precise and finite definition. Instead of being content to rest in belief of what can be known, should the truth be of such a nature as to render only a general proposition with regard to it possible, men will either disbelieve it, or not be able to believe it, unless they get rid of its indefiniteness by reducing it to some tangible, defined form or dogma, however unreasonable.

You see, then, that it is very important to settle the limits of the human intellect, that we may not fruitlessly 
expend our efforts, where no progress can be made, and may not be desponding on account of not arriving at certainty, where, from the nature of the case, it is impossible. We shall thus seek for truth where it can be found, and cheerfully acquiesce in what we can obtain, without disquieting ourselves about what lies beyond our grasp, and therefore can not concern us. Now, at the very basis of all your queries, lies this one-6 What can we know?' and without some conception of the capabilities and limits of our faculties, we shall never be able to settle it, and will ever be liable to be drawn away after the ignes fatui of speculations, which we might have known could not possibly conduct to any region of certainty. You will not, of course, desire from me here, a scientific system of metaphysic, it would demand a volume; but what is necessary is a statement of the fundamental principles which must guide us in seeking a reply to the questions which agitate your mind. Or, to come directly to the main point, what are the limits of our faculties? That we are limited on one side by the senses, is too evident to admit of argument. And yet, it is equally certain, that the senses give us only phenomena, and not any knowledge of the essence of things. But this, at least, is connected with our sense-experience, that it assures us of something objectively real, of a world that is not ourselves, and whose existence we can not deny, unless we involve ourselves in very subtle dialectics. Even then, the reality of the sensations remains; and hence, to whatever delu- 
sions and mistakes our senses may be liable, we must believe that they give us conviction of a real, objective universe. This is a conviction universal to human nature, and arises from the senses bringing us into immediate contact with the object of sensation. If this contact was not actual, immediate, there would be doubt of the reality of the object which awakens the sensation; and it might even be doubted whether the senses could at all furnish sensation from without, if they did not come in contact with an object, and whether the sensation proceded not wholly from within, and through the senses only projected the imagination of an external object. If the soul itself, does not immediately, by its comnection with the nervous organization, come in contact with the objective world, and thus directly receive the sensation; then the fact or reality of the existence of any object as the exciting cause of the sensation, could only be inferred, and hence there could be no absolute certainty of an objective world, but it would only be a logical conclusion, a probability, which might be destroyed by dialectical acuteness. But here the universal conviction of humanity that there is a real objective world, confirms our individual sense-experience; and thus we hold that we possess a direct intuition of the existence of the objective universe. On this side, then, of our faculties, we are limited to the sensations which the senses can furnish; while the attention of the mind being drawn to the purely subjective sensation, excited by some impression upon the nervous, material organization, and 
thence to the objective cause of that impression, perceives directly the existence of the outer world.

Now, on the other side, we are limited by the understanding which can only employ itself upon material furnished by the senses and reason. When perception is awakened, the understanding comes into exercise, and by reflection forms conceptions, distinguishes and compares relations, generalizes, classifies, judges and reasons. Its processes are exclusively logical, and furnish the forms of thinking. Those very processes imply that the material must be furnished to the understanding, before it can come into exercise; and so, the forms of thought, must be empty, until the elements of knowledge and reflection are supplied. All the elements or material of knowledge, lie in the objective universe and in the facts of our own consciousness; and since we can only acquire these by perception of the objective world and of our own internal sensations, understanding can furnish no material of knowledge, but can only act reflectively upon what is acquired through the faculties which place us in contact with the sources of knowledge.

It is evident, however, that the senses do not furnish the whole material of our knowledge. There are higher conceptions based upon a state of consciousness which the senses can not furnish, and which bears relation to a sphere of truth very different from anything to which the senses can introduce us. The perception of the beautiful, of moral truth, of the absolute goodness, the effort to grasp 
the real, the highest unity, beneath all the diversity of phenomena, the instinctive effort to solve the problems of the universe, of existence, of God, of immortality, the conceptions of eternity, of the infinite, of ultimate, universal, necessary truths, all belong an intuition of supersensuous truth which is given by reason. It is unnecessary for me to point out to you, in detail, the distinction between Reason and Understanding; it is too clearly recognized by all the great modern metaphysicians, to require any longer a demonstration. It has ever been recognized by the great philosophers of every age, and you must be acquainted with the grounds of the distinction. The direct, presentative, spontaneous perception of supersensuous truth furnished as material by reason, is, like the perception furnished by the senses, subjected to the formal processes of the understanding, and thus becomes the ground of conceptions, propositions, reasoning. The senses and reason, give us the concrete, experimental basis, - the understanding gives us the scientific form, of all our knowledge.

It is upon these principles, drawn from an analysis of human consciousness and the operation of the intellectual faculties, that we can determine the limits of our possible knowledge. We can know nothing, the material of which is not given us by experience; that is, either by the sensations furnished through the senses, giving us intuitive perception of the objective universe; or by the experience in the depths of the consciousness, furnished through 
reason, giving us intuitive perception of supersensuous truth. And this material given by experience, only becomes clear and comprehensible knowledge, capable of being intelligibly communicated to others, so far as it can be subjected to the forms of the understanding. If it can not be comprehensibly stated for the understanding of others, it may be valid for us, but can not be for them. And even if so stated in a degree, yet it can not be valid for others any further, than they are capable of the same experience. There must exist corresponding conceptions, in order that a statement may be comprehended; and those conceptions must be such as would arise from the actual or possible experience of humanity, or else the statement and its conceptions would transcend the sphere of the human faculties, and would thus be useless for man.

The limit, then, of our faculties and knowledge is experience, actual experience for ourselves, and as to what we receive from others, comprehensible and satisfactory testimony, as to what can be understood to have been possible experience. On one side our knowledge extends through physical science, and all which can be derived from facts acquired through the senses; (and here we would not expect to learn anything with regard to great moral problems,) and on the other side, our knowledge embraces the metaphysical sciences, and all which can be derived from observation of man's mental phenomena, his convictions of right and wrong, and of beauty, truth and goodness. Now when we come to inquire what we can know 
respecting the origin of the universe, the nature of God, immortality, and futurity, it is perfectly evident, from the view of the faculties just taken, that no amount of thought and reasoning, can possibly give us any knowledge concerning them, because they lie entirely beyond the possibility of our experience; and we can only form logical inferences, respecting what may probably be true, from the intuitions of reason. It is true, however, that the inferences we are led to draw from our perceptions of moral truth, and of the necessity of an absolute being, aford the strongest moral ground for believing in the actual existence of an intelligent God, and of a future life. And hence we have a strong incitement to virtue and hope. If we can know nothing beyond this, what does it concern us; and why should we not rest content? The most passionate efforts, the most miserable discontent, can never avail to enlarge our faculties beyond their necessary limits, although they can avail to make us pervert and misuse those faculties, which we are sure, from our own consciousness, can be employed in the acquisition of attainable knowledge, and the cultivation of cheerful virtue.

But we need not plunge into boundless speculation and scepticism. There is a religious sensibility implanted in our nature, which, when awakened, leads us still more earnestly to believe in the reality of that God and that immortality, whose probability is so forcibly pressed upon us by reason. That there should be a necessary existence, the ground of reason, cause, intelligence, and design, the 
author of the material and the supersensuous worlds, that is, of the visible universe, and of law, morals, truth, goodness, beauty, is the most necessary conception to reason, as the support, the basis of all her speculations, reasonings, and hopes. And hence there is nothing upon which she is more strongly justified in believing and acting, than the existence of a Supreme God, who is the origin and end of her existence. As to the hypotheses of atheism and pantheism, it is to my own mind a sufficient and indeed unanswerable objection against them, that they afford no adequate solution of the universe, of the facts of our own consciousness, nor any satisfaction to the religious wants and instincts of humanity, which can never cease feeling after a Personal God. The powerful reasons which impel us to believe in such a Being, lead us to believe that so important, so invaluable, so necessary a belief, will not always remain a mere probability, (although of the strongest kind,) deduced from the convictions of reason, but that God will manifest his existence, for the assurance of man, in the pursuit of virtue, and in the hope of immortality. But such manifestation, it is my belief, that God has made to men at different times; that is, that $\mathrm{He}$ has given to men a positive assurance of his existence, and elevated their reason to perceive moral and religious truth with the certainty of intuition. Can we, then, know of such manifestations; are any of them authenticated to us? I believe that such manifestation was made in christianity, and I will briefly state to you the grounds of my belief in this fact. 
The whole observation of nature, of the convictions of humanity, of my own conscious possession of personality, will, reason, moral sense, every thing, indeed, which I can observe, lead me irresistibly to believe that there must be an intelligent, Personal God. If there be, it is reasonable to expect from Him a manifestation of his existence ; and if he exist, his power to make such manifestation can not be denied. Christianity appears as claiming to be a manifestation made by God through Christ. The history of Christ, (which must determine the truth of the claim which christianity makes,) is given in the Gospels, and when I come to examine the history and credibility of those books, I find that they can be traced back, by such an array of testimony as no other ancient books in the world rest upon, to the period when christianity appeared in the world. They were in existence, and so widely disseminated, within so brief a period after the crucifixion of Christ, (the facts of whose life, remarkable character, death, and the appearance of his religion, are testified to by jewish and pagan writers, some of them contemporaries, ) that there is no reason to doubt the then general belief, that they were written by persons who had been with Christ, and that they contained trust-worthy memorials of his life and sayings. The evidence of this you may see in Dr. Norton's work- "The Evidences of the Genuineness of the Gospels." The first volume especially amounts to little less than demonstration of the two propositions, "that the Gospels remain essentially the same as they were origi- 
nally composed,' and, 'that they have been ascribed to their true authors.' You will not suspect me of receiving such propositions upon slight grounds, knowing, as you do, the sceptical character of my mind, and my contemptuous estimate of mere assertion and 'authority.' I refer you to Dr. Norton's work because he discusses the question as a purely historical one, and asks from the sceptic nothing as to dogmatic points. Now from a conviction of the real historical value of the Gospels, it is impossible to avoid the conclusion that Christ did make from God a revelation of religious truths. The writers of the Gospels, evidently wrote, after his death, such facts as they best remembered or had materials for, independently of each other; and while this naturally produced discrepancies in their narratives, yet their personal intercourse with their Master, gave harmony and unity to their relations, as they recorded the results of their own observation. The consequence is, that from all which they say, I am forced to conclude that Christ was the most astonishing and important character the world has ever seen; that he was miraculously introduced into the world without any human progenitor; that he was essentially and mysteriously connected with God; that he wrought miracles; elevated the spiritual perception of his Apostles, in order that they might apprehend truth as none others ever did, and might thus plant his religion in the world; and that he died in some manner for the redemption of mankind; rose from the dead, returned from earth to God, and was the author, 
through his religion, of the amazing change in civilization, politics, morals, intellectual development, which has since been operating in the world. Such facts as these, awaken us to a sense of a new relation towards God, and when I peruse further the Epistles of Paul, I am convinced that God manifested himself incarnately in Christ, in order to place the whole human race in a new relation towards himself and truth, and futurity, and to introduce new elements of development, and a new religious life into humanity, by having thus taken it into actual contact with himself.

But I find also a christian experience which assures me of the truth of christianity in another manner. The sense of sin which is always excited when the religious sensibility is awakened in view of the conception of God's holiness, perfection, and majesty, and which lies at the root of all man's systems of religion, moving him to seek some means of re-union with Deity, is perfectly relieved forever by the conviction that Christ redeemed mankind, reconciled them to God, and placed them all in a state of salvation; that is, made them heirs of happy immortality, if they will not cut themselves off from this condition, by disobedience to his system of virtue, faith, and holiness. The moment one is awakened to feel his need of just such a glorious provision, such a divine Saviour, and realizes the love of God in Christ, as a reconciled father, ready to receive all who will not choose evil rather than the gentle and noble law of charity and faith and purity, 
which the Saviour has set forth, then will he perceive the adaptedness of christianity to all the moral and religious wants of his nature; and in proportion as the religious life becomes developed in his soul, so will he realize a peace, a hope, a source of support and consolation, an elevation and ennobling of his nature, a sense of the living God, as his father and his friend, which will afford him a conviction of the truth of christianity impregnable to scepticism. This experience, this awakening of the reason and religious sensibility to the intuitive perception of christian truth as adapted to our wants, and commending itself as from God by its vital realization of the christian life in our own consciousness, is the only evidence which is capable of fully reaching christianity, so as to prove its power and reality to the individual. And this evidence, any and every one may possess, who realizes the necessity of some religious food for the soul, some assurance of union with God, (which needs him to have been manifested in order that we may feel that he can be known, and that he does care for men; $_{3}$ ) and who satisfies himself of the historical credibility of the Gospels, and opens his eyes to the momentous conclusions which must thence follow respecting Christ and his religion.

I have already prolonged my letter to the length of an essay rather than an epistle, but I knew not how more briefly to state the grounds upon which you can find a reply to your queries; that is, the most satisfactory reply which can be hoped for in this state of existence. And I 
am sure, that in accepting christianity, and realizing the christian life in your own consciousness, you will experience such a satisfaction, as will leave you little trouble with regard to points upon which it is useless to inquire and impossible to be informed. Your letter shows that you are in earnest, and that you really desire a solid basis for belief and trust in God, for the satisfaction of the religious element in your nature, and for the hope of immortality. You must see that the only solid basis at all, is to be hoped for in a revelation. Once realize the credibility of the Gospels, and reflect candidly upon the conclusions respecting Christ, to which they must logically lead; and you will perceive that the phenomena of christian life can admit no adequate explanation, but that of its being an element kindled in humanity by God himself, manifesting himself in immediate contact with humanity, and propagated from age to age by his own cherishing Providence; and you will estimate the privilege (to say nothing of duty,) of believing in Christ as your Saviour, reconciling you with God, procuring you a glorious immortality, and furnishing you with the noblest and loftiest motives to virtue and holiness: While the very paradox of such a creature as man, with his religious yearnings and instincts, being left without a revelation, if there be a Personal God, will dispose you to examine christianity with intense interest, seriousness, and hope. *** 


\section{LET T E R I I I.}

ANOTHER LETTER FROM THE SCEPTIC.

* * * Your letter both surprises and delights me. I did not know that you went so far in your christianity; you certainly did not formerly. You did not once hold it to be more of a revelation than the philosophy of Socrates; but $I$ am convinced that any conclusions to which you arrive are based upon no shallow grounds or slight investigation; and $\mathbf{l}$ am delighted, because $\mathbf{I}$ already see a gleam of light which will dissipate many doubts. But I must explain myself more fully, as to my own views, which you could not have gathered from my former letter. I am not the utter sceptic which that letter, written hastily in a fit of despondency, might seem to indicate. However imperfect the demonstrative proofs may be, I hold that no sane-certainly no man whose moral sense is unperverted, can disbelieve in the existence and providence of God. Life would surely be else a fearful blank. But with a strong conviction of the existence of a good, a perfect, a Supreme Personal God, and with a serious hope of immortality, I have felt the contradiction of his not giving to man a revelation, and yet have felt a doubt as to the solidity of 
the grounds upon which christianity, as a revelation, rests. Its nobleness, its beneficence, its sublimity, I have felt, and have seen that if it be not a revelation, we can look no where else for one, and if there be no revelation, we must be in painful doubt with regard to what we would give worlds to be assured of. But I will tell you the grounds upon which I have felt doubtful respecting christianity. I have heard and read so much that has struck me as unreasonable, as mere assumption and dogmatism, and as actually irreconcileable with their own principles, both from the pulpit and in books of divinity, that $I$ have really been rendered indifferent to a careful examination of the evidences of christianity. The divines lay such urgent stress upon the necessity of holding certain formal dogmas, and yet differ so immensely as to the true system of doctrines, that no positive truth on the subject appears attainable. But if the Bible be a revelation, how can its meaning and doctrines be so uncertain? Words inspired by God himself, can not be so doubtful, and could not require so much critical ingenuity to adjust and reconcile, as is necessary for harmonizing different parts of the Bible. The very words of God himself, could not have become subjected to the uncertainty of transcription and interpolation; and even if these have made no essential change in the matter of the Bible, yet the ipsissima verba of God could never have been otherwise than exactly preserved by his own Providence; for if they, the very vehicles of truth, could give way to human substitutions, even if these latter preserved the essential sense of the original 
words, yet those being lost or changed, what certainty is there of the sense having been really preserved, and does it not create distrust if God's own dictation could be thus subjected to the accidents of human language? But the variety of different readings, although they may not affect the sense of the Bible, and may be indeed very trifling, yet prove that God's own words have not been exactly preserved, and that human elements have crept into the sacred books. Besides, the evident difference of style, the influence of education and of prevailing national opinions and prejudices, with the discrepancies, even allowing them not to be irreconcileable, which appear in the books of the Bible, prove incontestibly that the writers wrote as men, not as machines, as actual intelligent composers, exercising their own mental faculties, according to their respective degrees of cultivation. If then, they were inspired, where is the limit to be drawn, or how defined; and of what value becomes such an uncertain inspiration to us, who cannot know what the mental condition of the inspired was, nor how far they were affected by inspiration? And upon any view, the matter of the interpretation of the Bible, presents an endless field of controversy, and every Church sets up its own interpretation as true, and makes it of essential importance to assent to its system of doctrine. All can not be right; nor can each one have only a fragment of revelation, for this would not be consistent with the unity that a revelation should possess; nor can it be confined to only one, for this would invalidate the truthful character, as intelligible to all, of a revelation, 
since all profess to possess it; and it is impossible to say which one does, especially as all profess to hold to certain principles in common. I pass over certain further difficulties with regard to the inspiration of parts of the Old Testament, and ask you for further information as to the satisfaction christianity has afforded you respecting God and futurity. You say that you have satisfied yourself of the historical character of the Gospels, and that they, being credible, lead to such views of Christ as you have stated. Suppose me willing to take this upon your investigation and learning. We must take knowledge in nine parts out of ten upon the authority of others, and this is what ninety nine hundredths of the christians do, and must do, with regard to the inspiration of the Bible, and the doctrines they receive. I receive then for the present, the Gospels as history, and conclude that Christ was the Divine Redeemer of mankind. I promise to examine the evidences carefully and justly, and to hold myself ready to receive that awakening of the christian life, which a conviction of their truth is calculated to produce. But I ask you, meantime, to tell me how the questions of inspiration and doctrine are to be disposed of. How is any absolute certainty with regard to dogmas and interpretation attainable amidst existing discrepancies; or is each one to interpret for himself alone; and if so, must not doctrine be very uncertain and unessential, and even inspiration itself become doubtful? * * * 


\section{LET TER I V.}

REPLY TO THE PRECEDING.

* * * FEw things have more tended to infidelity than the extravagant theories of the verbal inspiration of the scriptures. They have all proceeded from false views of the nature of religion, and from man's instinctive inclination to have something sensuously or logically tangible in which to believe. If the Bible is every syllable inspired, then there is a positive basis for the most sharply defined dogmas one can deduce from it logically ; and with a fixed system of divinely diciated doctrines, men become more careful and anxious about orthodox opinions than holy life, especially as others differ from them, and thus they are the more urged to zeal in defence of orthodoxy, than in cultivation of religion, and orthodox views and language become an offset for lukewarmness in spiritual life.

But take a general view of the whole subject, and you will perceive that christianity can not be touched or shaken by any theories of inspiration; if it can be, then indeed would its divinity become doubtful.

What renders religion and revelation at all possible for man? The same which renders all knowledge, all science 
possible, faculties adapted for its perception and comprehension. Religion appeals to and rests upon ideas, which the senses can not give, upon conceptions of which the senses can furnish no material. The great moral intuitions of reason, the ultimate conviction of right and wrong, of accountability, of God, the religious sensibility in man, these are the only criteria within his possession, whereby he can understand and judge of religion and revelation. These must exist in every man, capable of being awakened into exercise when the corresponding truth is presented, just as much as the perception of a material object is awakened when the contact with that object produces sensation. If this was not so, then all except the special recipients of a direct revelation, would be obliged to believe in God, and holiness, and moral truth, upon tradition, or hearsay ; they could not know at all, but could only say 'perhaps,' or 'we have been taught so.' Now undoubtedly we can not logically demonstrate the being of God, but we can do better, and more; we can, by the very moral intuition of our reason, perceive, upon the presentation of the matter, that there must be a God, that neither our reason nor religious sensibility can do without a God, and this spiritual perception becomes clearer and more vivid the more our moral intuitions and religious sensibility are awakened, so that we attain a conviction of the reality of God's existence and providence, deeper and far more important than any logical demonstration. To this conviction must revelation appeal; and a man must realize 
the truth of that appeal for himself, he must find it true in his own consciousness, or he can know nothing about the matter, except by hearsay.

A revelation must undoubtedly be designed to elevate man's moral nature and to raise him towards Deity. I believe that God (let us pass over now every thing else, other times and people and circumstances,) in Christ reconciled the world unto himself, placed the human race in a new relation to himself and progress, and introduced the highest awakening of the religious sensibility and moral intuitions, into the world. This has actuated itself in the christian life. This life propagates itself in the human consciousness, by all the means provided in the providence of God for christianity's coming in contact with the soul of man; and one of these means is certainly the writings of the scriptures. That the christian life can exist independently of the scriptures is undeniable; but how important the scriptures are, is evident from the whole history of christianity. What is the design of the scriptures? To furnish food for the spiritual life of man. This they have proved themselves abundantly capable of doing; filled as they are with the experience of men whose religious sensibility was awakened by God to an astonishing degree. Just take up, after a common book, an epistle of the great Apostle, and see whether you are not struck with the fact, that that man wrote under the influence of religious motives and religious experience far deeper and more vivid than any thing which the whole compass of christian 
literature since can exhibit. If one can not perceive this for himself, if he have no religious sympathies or conceptions in common with the Apostle, whereby to perceive his depth and power, and feel his own spiritual life quickened by those burning words, then he can never know whether the Apostle was inspired or not. How can he? He is told so by fallible and uninspired men. Of what value is an inspiration that must just be taken on trust, on the testimony of uninspired men? How are we to judge of the truth of that testimony, which does not concern a visible fact, cognizable by the senses, but a subjective matter which no one could possibly testify to but the subject himself? All that the Church can attest is, that these are the books which have been believed to be inspired. The testimony of christendom in this respect is valuable, because it confines our queries to certain books and no others, and excites a strong presumption in favor of their extraordinary character. But their actual inspiration beyond other books must, and can only be determined by their appeal to our religious nature, through their own religious character. But take a christian man who has realized the vital power of the christian life in his soul, and ask him if he would feel himself obliged to relinquish his belief in christianity, if it were demonstrated that the Pentateuch was not genuine, that the historical books were not authentic, that the Prophets give no prophecies, that the Gospels (let us put the strongest case) are only traditions about Christ, written not by eye- 
witnesses, and what would be his reply? He would sayIf all that was proved-here is the undeniable fact of the power of christianity, realized in the christian life, realized in my own consciousness, and notoriously going back to Christ as its author; it satisfies every religious want, it ennobles and purifies and consoles and animates, and the scriptures contain ideas, vital elements, which kindle, foster, and further that divine life in the soul; and therefore I can give up nothing which rests upon facts of my own consciousness, whatever you may make of historical questions.

Or, take another view, the Gospels are credible, as imperfect memoranda of Christ, no more, we will suppose. Now if the Pentateuch be only agglomerated traditions; if " the jewish history be half fabulous, what has this to do with the facts of Christ's life, work, doctrines, and influence? If the prophecies, moreover, be nothing but songs of lofty genius, then, at the most, the most extraordinary Being, the Divine Redeemer, would have come into the world unforetold, unexpected; but this can not touch again the reality of his life and the effects he has produced. Nor will it avail the infidel to say, that as Christ sanctioned the jewish scriptures, if they are not what they claim to be, then the mistake of the Redeemer is fatal to his own claims. Because, the burden rests upon the infidel first to prove how far, in what respect, for what purpose, Christ did refer to those scriptures; and until he can destroy the historical existence, the mighty power of 
the life of Jesus, the eternal impress which Christ has left upon the heart of humanity, he can assume nothing else; he can argue from no hypothesis as to Christ's opinion about the jewish scriptures, and he is bound to admit that if the history of Christ be true, then, supposing that he did sanction those writings as inspired, they must contain some element, which amidst all his critical acumen, the infidel has not discovered, but which the christian consciousness, ever drawing spiritual nourishment from the scriptures, has found and realized.* Let criticism, then, hold on her way, let her prove whatever she can about the mistakes and ignorance of the writers of the Bible,-that granite book, more enduring than pyramids and obelisks, will ever be enshrined in the religious consciousness of the church, because amidst tradition, error, poem, story, there still live the immortal visions of men whose spiritual intuitions were awakened to see moral and religious ideas, as none others did, that they might utter deathless voices to the echoing heart of humanity. And this is most wonderful of all, that if the Bible be full of myths and false notions, and narrow national prejudices, and human follies, it is still just there, amidst all that venerable rubbish, that the greatest and most stirring words which have ever reached the ears of man, the loftiest and mightiest ideas of moral and religious power which have ever moved the race, are found, clothed with a deathless energy which all

$$
\text { * See Appendix A. }
$$


the rough material in which they are set can not repress, and which impart a glory to that very dross, such as the light of Grecian wisdom can not shed over the dark pages of her polluted literature. Take the scriptures, then, wisely, as they were given a blessed boon from God, a practical book for kindling and freshening and elevating the moral and religious consciousness, and you will be troubled by no results of criticism or science; while as you make progress in the divine life, and approach the high spiritual intuitions of Prophets and Apostles, you will only the more clearly perceive their inspiration.

The strict view of a literally verbal inspiration, is perfectly consistent with itself, although it leads to and necessarily involves so many absurdities and impossibilities that it would be waste of intellect either to defend or oppose it. But on the other hand, if it be abandoned, then it becomes utterly impossible to define inspiration precisely, to mark out its exact limits, to distinguish accurately between the divine and human elements, or to determine how the subjects of inspiration were affected by it. All which can be said is, that ine inspired were so elevated by God in their spiritual perceptions, that they perceived supersensuous truth as clearly as we can perceive material objects submitted to our direct observation, and therefore could state supersensuous facts with the same accuracy and freedom from error, as we can state facts with regard to material objects which we have touched and seen. And it might be added, that they were 
kept moreover, from the actual commission of error as to the statement of supersensuous truth. All this large supposition, however, would still leave the bounds and nature and extent of inspiration undefined, and after all, as I said before, the only test by which we can know for ourselves the inspiration of scripture is its appeal to our religious and moral intuitions. For when we consider the difficulties of interpretation, the discrepancies and disputes of interpreters, the obscurity and variableness of the whole matter, any theory of inspiration will serve little, where the inspired records themselves are as obscure and difficult to be interpreted as if no inspired light dwelt in their pages. And it is notorious that the very points which differing sects regard as of most vital importance, are precisely the points upon which inspiration seems most obscure, and interpretation most ambiguous. Common sense tells us that it is folly to involve ourselves in such dim subtleties, but that if God has spoken, he would speak for love, for mercy, for guidance, and not to lay dark traps of enigmatical oracles for the poor understanding, which amidst the differences of the learned, does not happen to light upon the only true interpretation. Moreover, it is folly to weave up christianity with the historical criticism of the jewish books. It will live and influence the deepest hopes and convictions of men, though the jewish scriptures be proved to be unauthentic, and the New Testament to be uninspired, because it is a divine life, based not upon critical and historical questions, but upon the living con- 
sciousness of christians, derived from Christ and nourished by the Holy Spirit of God, and hence as indestructible as the soul of man. It is only in proportion to the want of a realizing sense of the power of christianity and of the spiritual life actuated in the soul, that men seek to hang their belief upon historical evidence and systematic dogmas. These supply the place of something tangible and appreciable to those who possess not the deeper and more vivid reality of the spiritual life in Christ and God. This is not founded upon history and dogma, but upon consciousness, experience; and thus it can afford perfect liberty to the critic and scientific man, as it can dispense with the shallow dogmatism of the sectarian partisan.

Thus it is that excessive dogmatism grew up, and orthodox phraseology, and even orthodox modes of feeling, became important, as spiritual life grew feeble. But doctrine was ever the attempt to express reflectively and logically the christian consciousness at each stage of its history and development. Hence its mode of expression has varied in every age. But as the ultimate facts, the fundamental unity of the christian consciousness, must be always the same, so in all the varying and contradictory expressions of doctrine, there will be found a certain universal underlying principle, which is true, as springing from the christian consciousness itself. The Bible at first was interpreted by this consciousness, according to the measure of its spiritual growth; and as this became less active and pure, the Bible came to be interpreted more by 
the mere understanding, and hence arose differences, disputes, complex systems, and astounding dogmatism upon points required to be received or rejected for salvation; but on which, from the nature of the case, it was impossible that finite human intellects could be informed, or could even comprehend the bold terms which they employed, and which they required to be received as possessing some sense, although repugnant to reason, crushing to understanding, and contradictory in themselves. Hence arose the cry about submitting reason to faith, as if they could possibly be in opposition; and the fact of subjecting understanding to superstition and credulity, as if christianity was a dogmatic ritual service, and not a holy life in the soul.

It might seem, then, impossible to deduce such a logical system of doctrines from the scripture, as can be so absolutely established that one may say- ' this is demonstrably true, all different interpretations are certainly wrong.' It is impossible. If it were not, it would have been done long since, even from the beginning. But where is the system of doctrines which is not historically demonstrable as having been gradually formed, and as not having commended itself to the universal christian consciousness? If christianity is only a system of doctrines, who shall decide, among differing churches, in which christianity is found truly and unmutilated? If christianity is also a sacred life, a vital experience, then no church can arrogate exclusive claims, because the christian life is 
most truly found in other churches; and if their system of doctrine be wrong, it affords a positive proof that christian life does not depend upon logical deductions. But if the christian life exists and develops itself, as it assuredly does, in churches which deny the correctness of each other's system of doctrine, there is no tribunal to settle which system is correct. Each individual would thus appear necessitated to decide for himself as to doctrines; and this would still more diminish their value. But happily this is not the case. An individual cannot decide absolutely for himself as a man; because he is not a mere absolute unit, but by his very participation of humanity, he is indissolubly connected with his race, shares its reason, its nature, its development and progress. So likewise, as by being a man, he is in sympathy with the common consciousness of humanity, and thus is partaker of its common sense and experience; he is, by being a christian man, in sympathy with the common christian consciousness, and in it finds a guide for his individual judgment. This christian consciousness has ever striven to give itself an objective expression in doctrines, as the logical embodiments of its perceptions. Hence, in all universal christian doctrine, however differing in logical statement, there will be found an essential basis of ultimate truth. The scholastic forms in which it is clothed, may be varied, or differently expounded, in different ages and churches; the eternal material truth, will ever approve itself to the consciousness of christendom. Even if the Apostles were not 
specially inspired, yet admit that they soberly knew what they were writing about, and what an amazing dispensation of grace and glorious mercy do they declare,-what a surpassing intuition of moral and spiritual truth,-what an unrivalled depth of experience do they display! The man whose religious sensibility has been awakened to his glorious relation towards God, through the Personal Redeemer, and who is earnestly striving to realize more and more the christian life of purity, love, and faith, will neither find his christian liberty abridged by any human deductions from the Bible, nor his christian experience an alien in any church of fellow believers. *** 


\section{E T T E R V.}

ANOTHER LETTER FROM THE SCEPTIC.

* * * Ir appears to me that there is no logical standing place between the admission of christianity and some mode of pantheism. If we reject all revelation, we can know nothing of the universe beyond physical laws, and we can do no more than guess that there may be a Personal God and another life. What was called "deism," never existed until after christianity was known; and evidently derived all its notions of God and moral duties from christianity itself. But if christianity be rejected, we must go back to the period before its appearance, to know what views may be held which are not (even in suspicion) indebted to christian notions for their shape. Christianity had been for so long a period influencing the world before modern infidelity appeared, that it is impossible to say how much this derived only and solely from nature, and how much from the christianity which had, for such a length of time, been shaping and influencing the mind and development of men. No such views of God and morals and immortality as are found in the writings of the best of the modern deists, can 
be detected in any writings of Greece or Rome. But even if the modern deists could show that their ideas were absolutely independent of christianity altogether; still, without revelation, nothing can be positively asserted respecting Deity and futurity, and hence, where nothing can be known, the philosopher will not dogmatise, and must admit that the pantheist may prove to be as much in the right as the deist. I confess that the old school of deistical infidelity appears to me very shallow, their arguments could only deceive the unlearned, but then they are put with so much acuteness, with such an exhibition, in many instances, of talent, that as very few persons are ever learned, they are calculated to influence many able minds, whose religious sensibility is weak. But the only form of infidelity which in the present day can hold a learned or philosophic mind, is the pantheism of Germany. To reject christianity, and yet stop short of that, is either superstitious weakness, or feeble logic, or meagre information. When Fichte, Schelling, and Hegel, with their genius, profound learning, and powerful logic, have written, it is as little-minded to hold to the shallow, unlearned schools of the old English, or the French deists, as to adhere to the early chemists, when we have the researches of Davy and Faraday. I must admit, however, that the principles which you have suggested, afford a reasonable ground for the reception of christianity. There are two points especially, which 
appear to me worthy of grave consideration. One is the existence of a christian consciousness or experience, which can not be denied, it is a historical fact. It has very remarkably manifested itself under every variety of circumstance and modification; and however influenced by, is evidently not dependent upon or arising from, belief in a system of doctrines; many believe such systems who certainly are not, by their own profession, partakers of the christian life. This is based upon the realization of a certain relation to God through Christ, and can only be adequately accounted for by referring it to the origin of christianity itself. This origin was either mythical, and thus a most extraordinary delusion has propagated itself as a powerful phenomenon of human consciousness; or it was really historical, that is, arising from Christ himself. If he had not been a most wonderful Being, he could not have given an origin to christianity and its controlling life. This life can not be a delusion, the facts with regard to it, the testimony to its actually being experienced in the souls of men, are too undeniable, although it is apparently accompanied by enormous delusions, springing from peculiar doctrines which are held as essential parts of christianity. But if there be a tithe of historical truth in the Gospels, if any reliance is to be placed (as you say there is,) upon the truth of their representation of Christ in his life and sayings; if he gave actual ground for such records about him as the Gospels contain, then, I can- 
didly confess, that I see no honest or unprejudiced or logical stopping place, short of his having been the Divine Redeemer.

The other point $I$ had in mind is, that according to your principles, one can find a reasonable ground for believing in christianity without confounding it with the systems of divines; and that there is a real basis of truth beneath the dogmatic forms of the church, which can be known by an appeal to the universal consciousness of christendom. For example, if I understand your principle, you would say-there is the highly figurative dogmatic expression in the document known by the name of the Apostles' creed, declaring that Christ "sitteth on the right hand of God," which, if required to be taken absolutely and literally, would be rejected by every one but a gross anthropomorphist. Now, if any where strictly literal language should be used, it ought to be in a creed, which sets forth literal facts, the actual and exact basis of belief. But if in one case, such notoriously figurative language is employed in such a document, it may justly be in other instances, and especially in prayers and hymns. The point then, is, what does such an expression as that quoted rest upon? And appealing to the universal christian consciousness, it undoubtedly embodies the expression of that conviction and sacred belief in the surpassing character of the Redeemer which assigns him the place of highest honor and dignity in the universe.

I see plainly, however, that the mere belief in historical $4^{*}$ 
christianity, the deepest searchings into scholastic divinity, can never make a man a christian in your sense ; but one must find Christ, as a Redeemer, and his teachings of virtue, holiness, hope and love, suited to his own spiritual wants and realized in his consciousness as a controlling life. This is the most philosophical ground upon which you can defend and urge christianity, for that which becomes a fact of experience and perception, is beyond the sphere of scepticism; and as there is every moral inducement to be a christian, I doubt not that a fuller realization of the wants of my spiritual nature, a deeper development of the religious element in my soul, and a clearer conviction of the reality of Christ as portrayed in the Gospels, and enshrined in the faith of christians of all ages and climes, will eventually bring me from a misty scepticism, (in which I see the weak points of infidelity as well as the perplexities of dogmatic divinity,) to a realization of the christian life, unshaken by disbelief and unobscured by theological absurdities. What can be known I shall heartily receive; as to what lies beyond the grasp of our faculties, in the region of speculation, I shall not disquiet myself. *** 


\section{ETTER V I.}

REPLY TO THE PRECEDING.

* * * I wiLL only say, that the beginning of all religion, must be an awakening of the soul to God; and that a realization of the nature of sin-its opposition to God-and of the free and glorious redemption manifested by Christ, must be the beginning of the christian life. My most earnest desire is to indicate the reasonable and essential grounds upon which christianity rests ; so that in the new flood of infidelity which will pour in sooner or later, earnest and philosophical minds may not be swept away, or alienated by the narrow, untenable, dogmatic views and spirit of too many of the professed defenders of christianity. Their grounds of defence can not stand; and I would fain suggest, that in the fall of human scaffolding with which they have hid, and even endeavor to identify the divine structure of christian truth, there is that which can not be shaken, for it is eternal and indestructible. The views of inspiration, of authority, of ecclesiastical tradition, of systematic divinity, will be vastly modified; and there will probably be as great a movement yet, towards increased light, freedom from superstition, and 
vital holiness, as there was at the Reformation; and I would suggest to you grounds which can satisfy the intellect and heart of thinking and free spirited men, who examine for themselves, and upon which the church, and christian doctrine, and inspired scripture, can stand impregnable. I will only, then, beg your candid perusal of the following discussion, in which you will find the subjects of our letters more fully treated. $* * *$ 


\section{P A R T II.}

\section{A DISCUSSION}

OF SUNDRY POINTS PERTAINING TO THEOLOGY. 



\section{$1 N^{\prime}$ 'ROUUCTION.}

THE POSSIBILITY AND NATURE OF THEOLOGY.

From the most general point of view, Theology presents itself as that department of knowledge which embraces what is supposed to be known respecting the nature and. character of God, and the relations of man towards Him.

The first and most obvious fact with regard to the subject, is the immense discrepancy between the various systems of Theology, as the Hindoo, the Mohammedan, the Christian, etc. ; but upon a closer inspection, we find ourselves compelled to limit our investigations for truth in this department of knowledge, to Christian Theology, both because it is the prevailing system among the most cultivated and enlightened portions of mankind, as well as because all other systems have become virtually effete for the intellectual and learned, to such a degree, as renders it morally certain that they can never supersede Christian Theology; that whatever truth they may contain will be found embraced in this latter; and that if the religious element in cultivated humanity finds not satisfaction in this system, it can not in any other which is known. Even if it be supposed that that element can find its 
adequate satisfaction in a Philosophical Theology, which shall not be distinctively christian, it certainly will not be denied that it is unnecessary to examine any other system than the christian, to arrive at such a result; since if this fails, some Philosophical Theology must be at once adopted, without seeking the desired satisfaction in any of the known systems, mohammedan or pagan. At all events, whatever conclusions be arrived at, there are certain general principles and questions relating to Theology itself, which must be antecedently discussed, if we would proceed in a scientific manner.

The first query which naturally occurs, is-whence does Theology arise? Without entering into the history of religion, we can certainly deduce from the very existence of such a history, the fact of a religious element in man. Amidst the various subjective phenomena which are identified with the peculiar development of particular religions, there is one universal element pervading the whole, and belonging essentially to the religious nature of man. This is the sense of finiteness, imperfection, dependence, which seeks to attach itself to the infinite, the perfect, the supernatural and divine. Something beyond itself the soul must have to stay upon, and to satisfy its religious instincts. It must seek some solution of the mysteries of being, creation, death, and futurity; and when it is too debased to rise to the conception of a God, of destiny, of an eternal law, or of some sentimental abstraction of ideal beauty, it will cling even to the grossest devilism and magic. This 
religious element has even appeared in a remarkable degree, where many would least expect to find it; namely, in the great systems of pantheism, where it seeks vent in losing its sense of feebleness in the all-embracing infinite ; and even in the philosophic atheism of the acute and sceptical Lucretius, a lurking, instinctive superstition, can not wholly escape the critical eye. It is, doubtless, from this primary religious element that Theology takes its rise.

But although man is impelled by an inner necessity to speculate upon such subjects, and to form theories and systems of Theology, it does not thence necessarily follow (the contrary indeed we clearly see, ) that he will hit upon the exact truth, or not mingle inextricably truth with error, or arrive at a positively real Theology. Another query, therefore, immediately springs from the former, namely, whether any thing can be certainly known upon the subject, or how does a valid Theology become possible? The only solid principle upon which an answer to this query can be based, is self-evident; it is this, the possibility of conceiving and becoming satisfied of the existence of God. If a conviction of the existence of God can not be attained, all Theology must appear as mere empty speculation. The conception of God, however, can be, and is, attained, although it is only from man's selfconsciousness of his own reason, understanding, will, power, moral affections, convictions of right and wrong, and of accountability, that he is able to form any conceptions of the wisdom, power, attributes and moral will or 
law of Deity. It is upon these conceptions and facts of self-consciousness that a conviction of the real existence of God can alone be founded, and to them every proof of his Being and will must be addressed. It is, then, the first condition of a valid Theology that it does not contravene, but is accordant with, the universal reason and moral instincts or convictions of man. But still, a Theology based solely upon these conceptions, while it would embrace the vital conclusions that God must be just and good, and hence that only justice and goodness can please Him, would only amount to a reasonable hypothesis, and could not rise to an absolute character. For this, a revelation from Deity is manifestly necessary. If there is no revelation, it is impossible to affirm absolutely theological truth. Is a revelation, then, possible? If God be the absolute, unoriginated, intelligent cause of all existence, not bound by the fatal necessity of all inability to communicate with the intelligent beings whom he has created, a revelation is undoubtedly possible. If he be even supposed moved by some mysterious necessity in the infinite energies of his own nature, to manifest himself by creation, this would oppose no reason against the possibility of revelation, but rather, from the intimate connection with his creatures which such a necessity would involve, it becomes even more probable that that connection would manifest itself at times in the higher degree of revelation; the eternal energies of the all-sustaining Being coming forth in fuller manifestation through the 
finite intellect, as they put forth themselves at times in the mighty operations of nature. In short, God can not be conceived as the absolutely Supreme intellect, without the possibility of revelation to finite intellects being involved in the conception.

But although God be not bound except by the absolute and eternal fitness of things in relation to his perfect nature and infinite wisdom, yet the finite creature is bound by the conditions of its limited nature, and once constituted under those conditions, without their total change, a revelation is only possible to it in accordance with those conditions. Since, then, the finite intellect, from the very limitation of its faculties, can not comprehend the infinite, a revelation would only be so far possible and intelligible as it could fall within the scope of the conceptions and understanding of the finite intellect. Those conceptions might be elevated and that understanding enlarged by the revelation from Deity, but they would be the same in kind, and if the recipient of a revelation was to communicate its contents intelligibly to others, whose intellect had not been illumined in the same manner, then such communication must fall within the ordinary comprehension of men, or it would be valueless. The subject of a revelation from Deity could doubtless be assured of the fact of a special illumination of his intellect by God; but how could others be satisfied that the ideas which he declared as derived from divine instruction were really from such a source? If they were unin- 
telligible, no judgment could be pronounced upon them; if they were intelligible, by what criteria could they be judged to have proceeded from divine illumination? Prophecy could only verify itself by fulfilment, and could only afford indirect proof as to theological doctrines announced by the Prophet, since it would not necessarily follow that because he had predicted an event which mere human sagacity could not have foreseen, therefore his declarations as to duties and articles of belief were infallible. In the same way miracles would only prove the connection of the worker with a power beyond that of man; but could not prove that the worker was absolutely infallible in his statement of doctrines and duties. It is only through his actually existing faculties that the recipient of a revelation could receive and comprehend the divine communication, or communicate it to others, and unless a miracle was wrought in the minds of men to produce at once conviction,-when a fellow man declared to them that the ideas he communicated had been immediately given to him by God, they would be obliged to judge of the truth of his declaration by conceptions of which they were already in possession. That is, the revelation would approve itself to them by its accordance with the great principles of morality, reason, and the character of Deity, enlarging their ideas on these subjects, reaching their conscience, and taking hold of their religious nature and wants. If God gave an individual knowledge, surpassing, and wholly different from any which the faculties 
of man can comprehend, it could never be communicated by the recipient to others. A revelation from God, then, intended to be conveyed by the recipient to others, must be communicated to him through his ordinary faculties and comprehension. All which can be acquired through the faculties with which God has constituted man, is to him a revelation, as the knowledge of the objective world, and all which pertains to the subjective domain of intellect. God has bound up man in these conditions, as those by which alone he can acquire or receive any knowledge; and hence any higher revelation touching the will of God and spiritual truth, must be made by enlarging the ideas and conceptions and intellectual perception of the recipient, so that he may be able to communicate comprehensible ideas to others. As the only method by which we can communicate newly acquired ideas or knowledge, is through language, a revelation must also be communicable in intelligible language, and every recipient of revelation must relate in his own manner the subjective impressions which he has received, unless the conditions of his humanity be violated. A finite intelligence, then, (that is, a man, for we know nothing of the conditions of other intelligences,) can only receive a revelation in the same manner as all information is received,-through existing faculties, (or if he receives it in any other manner, other men can not judge of it, until they possess the same experience,) and thus receiving a revelation, he can only communicate it in the same manner as all men commu- 
nicate their increased information to their fellow men. And revelation thus necessarily passing into the sphere of language, must be judged as all other communicated information is, by the laws of language and reason. If, then, it can be determined that a professed revelation has really proceeded from enlightenment and information furnished by Deity to the finite agent of the revelation, a basis is obtained for a really valid Theology in the contents of that revelation.

But to obtain such a ground for Theology, it must first be determined how a revelation can be established. It must come to those not the subjects of an inspiration, upon the testimony of the deliverers of it; and in case they are removed by some interval of time from the original deliverers, upon the conjoined testimony of those who have recognized it as revelation. In every case, in which those to whom an alleged revelation is delivered, are not themselves inspired, the revelation must depend upon human testimony ; and as, from the very nature of the case, this can reach no further than the facts that such declarations were delivered and received as revelation, and that the original deliverers were of trust-worthy character, the whole force of the revelation must depend upon its own intrinsic character. That is, it must be probable as relating to matters of such import to man, and yet so beyond his ordinary means of knowledge, as to warrant the bestowal of information from God; it must contain intelligible truths of so superior a character, as to warrant the 
belief of their having been communicated by God; and it must approve itself to the conscience and moral wants of man. Revelation must thus be suited to the degree of development man had attained, in order that he might comprehend and judge of it, however it might be always adapted for enlarging his conceptions, and elevating him towards a higher degree of development. To us, then, who are at so great a distance from any original revelation on spiritual truths, and who must take the records alleged to contain such a revelation, upon very complicated testimony, as to their genuineness and authenticity; those records must be utterly valueless, unless they can approve themselves to our reason and religious nature, by their own contents. Whether they were revelation or not to those in past times,-if they do not meet our state of development, our intellectual, moral, and religious wants, in reference to religion,- - they can possess no vitality, no real utility, even if we admit that they were originally revelation. But a revelation to be valid for all time, for man in every period of development, and calculated ever to further his moral and spiritual growth, must contain truths which will ever be applicable to his religious wants, and ever vital for his conscience and moral nature. It is, then, to the intuitive reason and conscience of man, as a moral and religious creature, that the subject-matter of an alleged revelation must appeal, in order to establish itself as divine. For, if that character is only to rest upon human testimony, even should this establish the 
genuineness and authenticity of the records, many could never appreciate the complicated evidence and critical details upon which it rests; and even if the testimony be admitted, the question might still be asked, how can we know that God really communicated with the original deliverers of those records, and that their contents may not otherwise be accounted for? But as man is created with religious instincts, moral intuitions, and deep wants with regard to theology, which however perverted and darkened, are an original revelation in the depths of his own soul, it is to them all revelation must appeal; and by answering, elevating, satisfying them, that it must establish itself as truly divine.

The question now inevitably arises, with what must Theology occupy itself? A valid basis being given it, in a revelation which approves itself to the reason and conscience of man, what is the true function of Theology in relation to that revelation? If it would keep within its appropriate sphere of truth and certainty, it must encroach as little as possible upon the field of dogmatic divinity, where the systems carefully and logically built up by one, are demolished zealously by another; where theories once held as absolute divine truth, which it was sacrilege to doubt or question, are superciliously cast aside, as superannuated, in a succeeding age; where the doctrine, an assent to which is made a condition of salvation by one, is regarded by another as endangering the eternal safety of him who holds it; and where the endless con- 
flicts of diverse systems and theories, may well plunge one into despair of ever obtaining a certain reply to the query-'what is truth?' In this vexed field, the divine must battle for what he regards the true, or truest, system. Hard and ungracious is his task, but let him bravely battle on; contest must ever further the truth,- - time will vindicate the right, - God will protect what is truly his revelation. But it is the privilege of Theology to move in a higher and calmer sphere. If not freed from the necessity of doing battle for the truth, her contests are for no scholastic forms, no logical processes, upon which certainty is ever problematical, and which rest for their validity upon the acceptance of the individual judgment; but hers are the dignified, the vital, the heroic conflicts, in which the very "fortresses of the faith" must be defended. It is for religion itself, and not for the system of this or that man, or body of men, that she stands as champion. The true office of Theology is to vindicate the great religious truths which appeal to the deepest consciousness of man; to awaken him to a realization of the Personal God in whom he lives, who is at once the author and the end of his existence; to elevate his consciousness to a perception of the vital and quickening ideas which God has given to the world, through the experience of Prophets and Apostles; to purify him, by bringing him into contact with eternal verities; to place him in communion, as it were, with all the good and noble and holy of every age and clime; to cheer him on in the fulfilment of his eternal 
destiny ; and to actuate in him the religious life as a redeemed heir of immortality. Holiness is its lofty aim, and faith its immortal strength. It regards revelation, not as material given, whereon men shall exhibit their astounding temerity, in presuming to dogmatize upon the most abstruse and hidden mysteries, but as a moral and religious power for kindling in the soul a holy life, ennobling it with the faith and hopes of redemption, and empowering it by the love of God in Christ, to fight nobly the battle of life, until its immortal aspirations shall be swallowed up in the fruition of eternity.

When we proceed to apply these principles to the criticism of what is currently received as Theology, we find two elements which need to be carefully distinguished, and also a general fact of the highest importance. We find the element of religious sensibility and perception, with which Theology proper has to do, in cultivating the religious life in man; and we find the logical understanding, to which divinity addresses itself, in definite or sharply defined systems and propositions. We also find the general fact, that amidst all diversity and opposition, there is an underlying unity which characterises all as christian, in distinction from every other religious development. There are two points from which Theology may indifferently start. Either from the Being of God, and the probability and need of revelation which that grand truth involves, to the actual records of revelation as established and interpreted by the universal consciousness 
of christianized humanity, or from the phenomena of the christian life up to the revelation and its author in which those phenomena are grounded, and which alone adequately explain them. Having already stated the grounds upon which a valid Theology can rest in the truths and ideas of a revelation commending itself to, and realized in, the deepest consciousness of man, we shall briefly analyze the phenomena of christian life, in order to point out what are its universal, invariable and necessary characteristics, which stand forth as a beacon against enthusiasm, superstition and fanaticism, as well as against frigid formality, scepticism and rationalism.

When we distinguish what is material from what is formal-what belongs to religion from what pertains to divinity - what is the substance of truth and reality beneath the guises of form in which it is variously expressed, it is evident that amidst all the differences in christendom, even amidst the jarring of dispute and recrimination, there is something common to all as christian, in which any pretence to christian life or experience must profess to be grounded ; and this, as a fact, neither the coldest scepticism nor the haughtiest bigotry can deny. There is a universal principle beneath the various modifications of the christian element itself, upon which it rests, and in which the unity of the christian consciousness is grounded.

When the primary religious element is developed under the influence of christianity, it assumes a phase which distinctly marks it as christian, and distinguishes it from 
its developments in any other form of religious belief. It can scarcely be disputed as historical fact, that the central idea and ultimate aim of all religion is reconciliation. But the root from whence grows all development of the christian religious element, is reconciliation through a Personal Redeemer. However this may be supposed to be effected; from the most ardent and enthusiastic view of "conversion," to the coldest and most passive theory of an "opus operatum;" from the most strenuous conviction of "resistless grace," to the most absolute assertion of "human ability ;" there is still the unanimous grounding of all views of reconciliation upon the Personal Christ, as the author of the new relation of man towards God, Truth and Duty. It is by realizing a personal relation through the spiritual consciousness, towards this Personal Redeemer, that there is realized that confidence in God, wherein filial duty and love are harmonized in the sense of paternal reconciliation with the individual man. And it is the great practical problem of christianity, (the appointed means for the resolution of which we do not here discuss, ) to awaken the spiritual consciousness to the realization of that personal relation towards the Redeemer, and to foster and maintain the religious life of the soul. The most general characteristic, then, of the christian feeling of religion, we would state to be, that sense of confidence in God, wherein filial duty and love are harmonized in the sense of paternal reconcitiation through the Personal Redeemer. 
This characteristic, however, manifests itself under a variety of degrees and modifications, as it is more or less purely developed, and as the peculiar relation of sonship towards God, is realized with more or less clearness under the modification of accompanying conceptions. For example, where the conception predominates, of God ruling through a strict and defined monarchical polity, the sense of sonship will be modified by the feeling of the appointed service of the subject. Where the preponderating conception is of the absolute sovereignty of the divine will, in its own mysterious and secret counsels, the feeling of sonship will be modified by the sense of the subjection of all to the mighty decrees of the supreme wisdom and pleasure. Where, again, there predominates the conception of God as boundless love, the feeling of the relation of sonship will be chiefly merged in the grateful sense of the freely reconciled creature. And so, again, the sense of that peculiar relationship will be correspondingly modified, as there predominates the conception of God, viewed through the provided means of reconciliation, as they stand in relation to his own character, or to the wants and nature of the creature himself. So that strict and submissive duty, - or dutiful resignation and submission, - or confiding and trustful affection,- - or careful and thankful obedience,- - r earnest and grateful acceptance,-will come out most prominently in one or the other case. Not that they may not all be commingled in a certain degree; but that some one, as the case may 
be, will appear as the most prominent phase, under each predominant conception of God. We also know, as historical fact, that in various developments of the religious element in christianity, there prevail stern views of duty, or narrow conceptions of submission, or loose notions of obedience, or other modifications of the christian feeling of religion; as well, as that there sometimes predominates the subjective condition of the individual, or the objective appointed means of reconciliation, as the most prominent modifying element of systems of divinity. But we can trace through all these modifications, that sense of confidence in God, founded upon the filial relation realized through reconciliation by a Personal Redeemer, which characterizes the religious element of christianity.

Now, we are compelled to ask, what is the origin of this christian religious element? For eighteen centuries, the christian life has developed itself in humanity, flowing on in the consciousness of man, through every age, with undying vitality, actuating the same phenomena in every diversity of clime, development, and race, and supplying a boundless and imperishable aliment to the spiritual wants and life of man. We can fix the period when this extraordinary phenomenon began to manifest itself in the human consciousness, and it has ever continued propagating itself through that consciousness down the flow of time, like a mighty wave, gathering strength from its vast and onward swell. Under its impulse and control, a development of humanity has manifested itself, 
wholly different from any which preceded, and evincing that a new element had been introduced into the world. Civilization, politics, international and national law, social life, and intellectual processes in every department, have been signally influenced, modified, and directed into before unknown channels, by this mighty element. Even the region of speculative philosophy has felt its control; and the very sceptic who rejects christianity, is enabled to speak of God, morals, and duty, with a clearness and definiteness of apprehension, and a lofty nobility of conception, sublimely and infinitely surpassing all to which the highest genius of the world had attained before the introduction of christianity. And all which he can oppose to the origin which christians claim for this element, is the postulate that in the natural, uninterrupted progress of humanity, that clear apprehension, and those noble conceptions of God and duty, would have inevitably developed themselves. But such a position is entirely unphilosophical, in as much as it is at direct variance with the known course of human development. It is impossible to affirm what would inevitably have been the actual development of humanity, had any of the great facts in the chain of its moral and intellectual growth been wanting. Had not the Greeks existed, and received their peculiar development, and stood in the exact place they occupied in the history of mankind, it is doubtless true, that the development of the human race and its history would have been different from what it was; but 
it is impossible to take a phase of humanity, subsequent to the period assigned to the Greeks as their historical era, and to erect that into a postulate claiming any deference, as to what the development and history of man would inevitably have been, independent of the modifying elements alleged to have flowed from the Greeks. Nor can we any more, in philosophically examining the progress of humanity, strike out so obvious and undeniable a modifying element as christianity. The most we could do, would be to deny that the modern civilized world is indebted to that source for its sublime ideas of a Personal God, clothed with a mercy as resplendent and attractive, as the notions with which the ancients invested their conceptions of the divine, were gross, terrific, or Platonically undefined and shadowy. We may affirm that the lofty conceptions of morality and duty, before which every page of ancient literature must blush; or that the religious life of purity, holiness, charity, faith, and hope, of which, before christianity, the world had known no realization, and the best of the ancients had only faintly and confusedly dreamed, were no offspring from that astonishing element, before whose appearance in the world, those grand and vital ideas had been unknown or profoundly dormant. We must not only, in asserting such a denial, show how those ideas originated and took their place in the growth of humanity, but we must also explain the origin of christianity itself, and account for the coincidence of its appearance with the putting forth 
of those high conceptions, as well as for their invariable connection ever since with the progress and influence of pure and vital christianity. We know well that attempts to satisfy such demands, have been made with subtlety and ability, but they all involve the manifest sophism and assumption, that christianity itself is a gradual offspring from the development of humanity; while it evidently did not gradually grow into the world, but was at once introduced-a germ full of new ideas, which still in every age are loftier than the age itself, and pour forth exhaustless treasures to the ever increasing expansion of intellect and civilization; an expansion incited and modified by christianity itself, which arose, like a conquering vision of light, upon the mists and gropings of the world, from the midst of the retrograding, sinking civilization, and the rapidly petrifying vitality of the formal religion of degraded Palestine. At a period, when the world had sunk to such a point of demoralization and scepticism, as almost to justify the speculation of Plato, that there are cycles in which the world reaches such a condition of intense moral disharmony, as imperatively to call for the rectifying interposition of Deity, lest the whole frame of society should go to utter wreck, in the wild deluge of corruption; at such a period, when every hope of rational liberty, settled religious consolation and faith, and regenerating morality, seemed to have died out of humanity, in the vast and gloomy triumph of despotism, superstition, infidelity, and luxurious vice, there arose from the very 
base of society, in a wretched province, such a light, such a mighty, vital, regenerating element, as the world had never witnessed or experienced; and which has shaped, and elevated, and ennobled humanity in every subsequent development, with a deathless and ever growing energy. And now, when every thing indicates that humanity is to be hurried into a mighty battle for its most precious and vital possessions,-for the absolute basis of law and constitutional liberty, - of public morals, - of religious hope,-when the awful contest will rage around the very central life of man-the belief and trust in a Personal God; the vigor with which christianity gathers up her strength for the battle, undaunted, undismayed, is an earnest of her triumph,-is a proof that she is alone adequate to meet the foe,-is a glorious assurance that she is able to save the hopes of the world. She will herself be benefited and purified by the contest. The mists and corruptions, with which the lapse of centuries and the follies of men have obscured her divine lineaments, will be swept away; and she will again beam upon the world, as the uniter and sanctifier of humanity, radiant as she was in the Apostles' days with the glory of God.

But the christian life, which has existed in the world ever since the introduction of christianity, an actual experience, realized and propagated from age to age, in the vital consciousness of man, would exist, and grow, and continue, even if every record of the origin of christianity should perish. This christian consciousness is too wide 
spread, too manifestly recognizable under every variety of development, too deep-seated and sympathetic, too much inwrought into man's highest civilization and inmost-life, to be at all affected by the results of speculative criticism. Even suppose that the records alluded to could be indubitably proved to be rather mythical accretions, than veritable history, this could not touch the actual, existing fact of the power and vitality of christianity, as realized in the religious consciousness of man ; but, at most, it could only prove that we knew no authentic details respecting the wonderful Being, who so mightily impressed the energy of his own personality upon humanity, that it has modified its entire subsequent development, and lives ever in the hearts, the conscience, the hopes, the belief of men, although no positive history respecting his life has been preserved, but who was so awfully great and majestic and mighty and sacred, that within a half century of his moving among men, and leaving his spiritual image impressed forever upon the world, there grew up around the single central fact of his appearance upon the stage of life, the most wonderful myths which the word has ever beheld. What must have been his character, that the mere memory of his existence and the impression which he left in the hearts of men, could have gathered around them such a splendid halo as the Gospel narratives, weaving all the glories and hopes which humanity had ever lavished upon its Gods and Heroes and Redeemers, into a radiant crown 
for the most resplendent, consistent and divine impersonation of nobility, inspiration and holiness, which ever won the hearts and attracted the devotion of men! Christ, as the Personal Redeemer, the root of the christian life, is too deeply incarnated in the heart of humanity, too intimately inwoven with the dearest and noblest hopes, the most lofty and mighty motives, the most earnest and sacred life of man, to be torn thence by any historical destruction of the mere records of his life. More wonderful, more divinely mighty must he appear, who has thus introduced the greatest modifying element into the progress and development of the human race, which has ever influenced it, and thus lives in the consciousness of christianized humanity, ever extending his sway, while no reliable record of his life exists; a life whose reality and power are nevertheless immortally stamped in the history and the firmest convictions of mankind. So that we can only adequately account for the existing phenomena of the christian life, by tracing its vitality back to that Christ, whose actual existence, not even the hardy criticism of Strauss attempts to question, (for without that basis, at least, the Gospel myths could never have grown up,) and through that Christ, to God himself, who alone could have introduced that new and suddenly appearing, and astonishing element into the development of humanity. Strauss's theory starts from two postulates which he does not condescend to substantiate, taking them as acknowledged science, but a denial of which is 
fatal to the force of his arguments. One of them is, that there can be nothing miraculous or supernatural; and the other is, that within so brief a period as the time between Christ's flourishing, and the latest date which can be assigned to the oldest existing Gospel, it was possible for such a mythical legend to arise and shape itself, absolutely swallowing up every authentic fact, and yet embodying the most perfect conception of a sublimely harmonious, consistent and faultless character. The admission of a Personal God destroys the former assumption; the latter, which it is attempted to substantiate by a criticism of the internal evidence of it afforded by the contents of the Gospels, is invalidated by the direct external evidence to the substantial historical character of those books, and to the essential integrity of their existing text. Strauss's theory is the highest effort of criticism to destroy historical records. It appears that criticism can go no further, except in the denial of the very possibility of any history whatever; and his own words, upon the contemplation of his labors, are the truest and most eloquent judgment of what he has accomplished; they are the funeral oration, the perpetual epitaph, of such fruitless efforts. "The results" he says "of the inquiry which we have now brought to a close, have apparently annihilated the greatest and most valuable part of that which the christian has been wont to believe concerning his Saviour Jesus, have uprooted all the animating motives which he has gathered from his 
faith, and withered all his consolations. The boundless store of truth and life which for eighteen centuries has been the aliment of humanity, seems irretrievably dissipated; the most sublime levelled with the dust, God divested of his grace, man of his dignity, and the tie between heaven and earth broken. Piety turns away with horror from so fearful an act of desecration, and strong in the impregnable self-evidence of its faith, pronounces that, let an audacious criticism attempt what it will, all which the scriptures declare and the church believes of Christ will still subsist as eternal truth, nor needs one iota of it to be renounced."

Profound and philosophical insight! It is not in the record of the letter, but in the spiritual sanctuary of the heart, that christianity is enshrined and lives. And if it were possible to destroy the record, the Christian Consciousness would then, perhaps, form glorious legends of the mighty Christ, whose power and truth will ever continue to be actuated in the experience of man, thus testifying the divinity of the source whence it drew the first impulse of its immortal life.

What relation, then, does the christian consciousness bear towards the christian records? It finds in them a corrective and an exhaustless nourishment. A corrective against superstitions and notions unwarranted by the contents of the records, and an ever fresh and vitalizing spring of truth and holiness, for perfecting and elevating the religious life. The christian consciousness arose and 
took inerradicable root in humanity, before any christian records existed, and these were written evidently for the fostering and elevation of that divine life in the soul of man. Emanating from those in whom that life had been kindled by direct communion with its mighty author and his apostles, those records express the experience afforded their writers by God, with a depth, and vigor, and elevation of spiritual perception, far beyond anything that ordinary christian writings can present, unless indeed the writers be elevated by God to the same keen and vivid and extraordinary perception and realization of spiritual truth. They are the profoundest expression which the world possesses, of the affections, hopes, faith, consolations, charity, convictions of duty, of union with and redemption by God in Christ, with which humanity was ever inspired; and they will thus be ever regarded by the church as a most precious legacy. Basing itself upon the christian consciousness, upon christianity, not as a science, but a divine life,-Theology must ever strive to give more adequate form and expression to the subjective facts of christian experience, and to expound the deep, vitalizing, religious idea, which is embodied in "every objective expression respecting the relation of man to God."* Thus finding christianity actuated in the soul, the conscience, the spiritual experience of man, Theology will feel no nervous apprehension and jealousv at the

* Bunsen. 
boldest investigations of science and criticism; she will pronounce no profound conviction of an earnest soul, sincerely and candidly expressed, "dangerous," because it harmonizes not with some phraseology or dogma which depends upon the conviction of the individual judgment; and feeling assured that the christian life having God for its author, neither depends upon logical propositions or critical details, nor can ever die out of humanity, but will flow on sanctifying, ennobling, saving it, until the flood of time shall be lost in eternity; she appeals to us, by every demand of reason, to reverence, and love, and confide in the omnipotent God, whom we can not deny without abandoning and contravening reason itself; and who not only proclaims his existence to our intellect, but speaks in the depths of the conscience, as our Creator, our Judge, and our Father; proclaiming, through his amazing displays of goodness and redemptive mercy in the Gospel, that man's highest nobility, is his creation in the image of God, and his supremest glory, is his being conformed to the likeness of Christ. 


\section{H A P T E R I.}

THE IDEA OF GOD AS A NECESSARY CONCEPTION OF REASON, AND THE NECESSITY OF MAN'S THEOLOGICAL AND RELIGIOUS CONCEPTIONS.

WE propose now to investigate the grounds upon which the great truths of religion rest; to seek, the ultimate and absolute basis of all religious belief, of revelation, and of christianity, and to endeavor to suggest the claims which this religion possesses upon us, in its perfect adaptedness to fulfil all the intellectual and moral wants which man can feel in reference to religion.

Where then shall we begin? Not with revelation; for revelation itself presupposes many facts for its own validity. The Bible can not be adduced as the primary basis of all religious belief; for it professes to come from God, and presupposes the admission of the Divine existence, of his various attributes, and of the necessity of his revealing himself to man. The Bible may be the basis of belief as to what is the will of God, but it is itself no proof of his existence. It is a proof of what are really his attributes, and it is an irresistible confirmation of his being; but if we doubt that being itself; if we have no grounds leading 
us to affirm it, in vain will divine wisdom and eloquence beam from the pages of Holy Writ. How can we perceive them to be divine, if we have no anterior conception of divinity? It would be evidently fruitless, to endeavor to prove to us that, of which we possessed no corresponding ideas by which we could comprehend it. Useless to us, would be credentials from a czar, if we had neither grounds for belief in such an existence, nor any conceptions whereby we could understand what a czar was. But revelation comes to us, claiming to make known a Being, the belief in the possibility, at least, of whose existence, it assumes as the ground of its claims. And without some conception of what his character ought to be, how could we judge if the alleged revelation was probable, as being worthy of him?

Nor could miracles afford the requisite proof. If the universe, with its laws, exists by chance, apparent deviations from those laws, or facts which perhaps may belong to unknown laws, can never prove a First, Intelligent Cause. If the grand miracle of the universe attests no Creator, small miracles within the vast cycle of the universe, can never attest more. To make, then, revelation possible, we must first find an absolute ground for the idea of God. It is evident, that the establishment of this point is all important as the basis for the reception of the Bible, and for all religious conceptions whatever. But since it is indubitable, as a matter of fact, that we find ourselves in possession of the idea of God, we are bound 
to show how we possess it, that we may obtain a positive basis for certain belief. And, although this is a question which is discussed, not improperly, in the schools of philosophy, yet surely its discussion is equally proper and necessary for every christian man, whose duty and privilege it is to trust in that Being, whom to doubt were impiety, and in whom, for an educated mind to exercise an unreasoning belief, were unpardonable profanity.

We must begin, then, with an analysis of our own selfconsciousness; without which, indeed, there could be no unity in our experience, or possibility of our reflection, and hence no existence of thought. Unless man was conscious of his personal existence, of being the same individual, and of recognizing the operations of his mind and feelings, as always belonging to one and the same being-himself; experience would be an illusion, and thought, (as involving any process of understanding and reason) an utter impossibility. Now, when self-conscious man begins to think, the first general fact which must strike him, is, that there is something which is not himself, which is diverse from and external to him, and which operates upon his inner-self, through the medium of his senses. In short, he finds that there is a universe about him, and that but a small part of it indeed is subject to his control. The more he observes, and becomes acquainted with its phenomena, so much the more urgently do the questions press upon him-' whence came it? What sustains it, and originates its laws? What is its 
end and destiny? And what relation do I bear to it?' And when man's observation is attracted by what passes within himself,-when his contemplation is turned from the external world to the being who is the subject of its impressions, and who reflects upon the processes of his own intellect, no less than upon external phenomena; he again finds himself irresistibly compelled to ask- whence am I? What is the object, end, and destiny of my being? And whither do I go?'

The external universe alone, contributes somewhat, but still only an imperfect quota to the answers which he demands. As a vast mechanism, it suggests to him the ideas of intelligence and design; but having his own attributes alone upon which to build his conceptions, he can never rise from his mere contemplation of the material universe, beyond the notion of a hierarchy of humanlike deities; or, at the highest, of a great human-like creator. The mere idea of causation, which however is one of the deepest infixed in man's mental constitution, will lead him up through a series of effects, (for every secondary cause is but the effect of a preceding) to the necessity of an absolute, unoriginated cause; but it can clothe it with no personality, and with no moral attributes, except such as man can conceive from his own constitution. The ideas of existence, of change, of time, of space, will carry him on still further to the correlative ideas of Self-existent Being,-the ground of all existence, of the Changeless and Underived, of eternity, and of 
infinity. But of these, he can possess no experience through the senses; and however awakened or excited, they are ideas already in the mind, which can not come from the sense-world without, although they suggest the necessity of a real subject whereof they may be predicated.

Again, however, as man searches deeper into his own consciousness, he reaches a higher sphere, which contributes moral proofs towards his conception of Deity. The creator of mind must himself possess reason. And when self-consciousness is deeply fathomed, there is found to be in man a sense of moral freedom, lying at the very foundation of accountability, of self-approval and self-reproach, of a recognition of virtue and vice, of innocence and culpability, of reward and punishment; - a freedom which is the ground of all law, and which, however its exercise may be supposed to be affected by motives, must be presupposed as the ground of presenting any motives at all. The very conception of the exercise of moral freedom, presupposes a recognition of good and evil, of right and wrong, of justice and injustice, of virtue and vice; in short, of a moral law, as the guide of conscience. Moral freedom and conscience so reciprocally involve each other, that one can not exist without the other. Without the persuasion of freedom, in originating or abstaining from an act, it would lose all moral quality, and there could evidently be no conscience, or consciousness of error or rectitude; and the very existence of this conscience as a 
sanctioning power, however it may be misled by a per* verted or unenlightened judgment, is itself a testimony to the existence of some ultimate, objective standard, or rule of right and wrong, which is moral law reflected in universal human reason, and having its ground in a perfect will.

If virtue and vice were only conventional, there could be no ground for law in equity or justice; and the ultimate consequence of such a view, confounding the essential and eternal distinctions of right and wrong, would terminate in atheism. But the universal voice of humanity testifies that there is a rule-not of right, because most profitable, but of the most profitable, because the best and most just; and this at once points to an immutable standard, or rule of best and right. Such rule, in its perfect and ultimate form, must imply a perfect will by which it is imposed. But as will itself implies moral choice, then perfect will must always choose the best and holiest, and thus becomes identified with perfect moral law. And as, moreover, such perfect will must belong to perfect being, and perfect being admits nothing higher, - then the ultimate standard of right must exist and have its ground in the eternal fitness of things, in relation to the very nature of such being, and must be immutable, as the nature of perfect being must itself be immutable, or its perfection would not otherwise be absolute.

These ideas, however awakened, are not derived from the experience of the senses, and hence reason must seek 
an absolute ground for them in something above expe rience; and as she must also find such ground for her ideas of the infinite, the eternal, the self-existing cause, as well as of the perfect good, and beautiful, and true, she combines the suggestions of the universe, with the conceptions arising from her own consciousness and demanded by her own laws, and is thus led up to the logical and moral necessity of God. By thus tracing the idea of God to a necessary conception of reason itself, we establish the most certain basis for religious belief, and for revelation, since this latter can now appeal to the consciousness of man for the existence of the Being from whom it professes to come, $-\mathrm{a}$ Being whom reason can not deny without contradicting her own processes, and sweeping away the very ground, without which all reasoning, all existence, all nature, become an inextricable paradox. Whatever may first awaken the reason to the analysis of her own contents, whether spontaneous reflection, or philosophy, or the preacher, or the Bible, yet all must send her back to the idea of God which she must possess first as a conception, before she can understand, or compare with it, or enlarge it by, any evidences from without, and which has for her the highest validity in being necessarily found in her very constitution.

But, with this antecedent conception in the reason itself to appeal to and develope, all creation becomes radiant with the glory of Divinity. The vast "panorama of the universe," moving in majestic harmony around the throne 
of God,-a mighty reflex of his power and wisdom,grandly hymns in its ever-rolling cycles the Omnipotent and Ruling Artificer. The history of the nations, as humanity in its complex developments passes along the ages in rhythmic flow, evolves the vast plan of a gradually unfolding and mighty drama, which attests the Omniscient Providence, leading it on to eternity. The hopes, the throbs, the panting aspirations of the soul for the full grasp of knowledge, truth, and immortality, which make it beat the barriers of this dark and narrow earthly circle, like an imprisoned bird, proclaim the everlasting Father to whom it instinctively looks for deliverance, and in whose abode alone it expects the fruition of a weariless life of energy and bliss. Yes! reason must confess a God as her most necessary truth, or she becomes to herself the most dark and contradictory enigma in the universe. The speculative atheist himself, who denying the higher reason, confines himself to the sphere of the mere understanding, where he finds not God; is yet obliged to take refuge in an ultimate power, or law, or generative nothing, and thus bears testimony to the necessity which reason proclaims for an absolute ground of all being, all power, and all law. And the very impossibility of proving the existence of God, if the intuitive perception of reason be denied and rejected, is itself a demonstration that the mere logical understanding is incompetent to the task, and that we must find the conception already lying in the reason itself, as the ground 
of the possibility of any instruction with regard to it. Just, (for the sake of illustration,) as it would be impossible by any appeal to the logical understanding, to give the notion of a particular color to a blind man who possessed no conception of color at all; or to give the idea of the music of an opera to a deaf man, in whom the faculty of hearing had never at all been awakened.

It may be left to every earnest thinker to ponder upon the fact, to make clear to himself the vital truth, and to find by a close analysis of his own self-consciousness that he must believe in God; that he can not deny his existence without a conflict with reason itself, and that it is as antecedently necessary to reason for any logical thinking, or reasoning upon the universe and man, as are the first principles or axioms of geometry, for any process of mathematical argument.

Revelation has thus an indestructible basis in reason herself to which to appeal ; a basis which renders revelation intelligible and probable, and standing upon which, revelation leads up reason to the culminating point of the full glorv and light of Divinity. We find man compelled to account to himself for the existence of the universe and of his own soul, and to seek a solution of the problems respecting his destiny. We are not called upon to account for the origin of such questions in the mind. But yet the fact that man can not think without their naturally arising in his mind, and that he always has, moreover, been occupied by these queries, embolden us 
to refer them to a fundamental and original law of the intellect, by which it is compelled from its very nature to exercise its functions, to investigate, discover, examine, reflect, combine, deduce, account for; and in its faculty of reason, to strive ever to enlarge its sphere beyond the world of experience. And so this law of activity and exercise may, in like manner, be considered as lying beneath the equally certain and invariable fact, that when man's observation is attracted by what passes within himself, when his contemplation is turned from objective to subjective phenomena, he again finds himself irresistibly compelled to ask the questions respecting himself which have been before indicated. In other words, selfconsciousness in man, necessarily involves reflection, and reflection upon the external world, and upon the internal operations of his own being, necessarily awakens the questions which have been propounded. An individual may neglect, disregard, or smother such questions altogether ; or may be satisfied with a very inadequate reply to them; or may never seek or care for any reply at all. But this does not affect the truth of what is alleged, as to universal man, for it is unquestionable that such questions must arise to man, and moreover, that they have always been points which have most deeply interested, and universally engaged the exercise of human reason. Man will first be engaged upon his physical, temporal, and social wants; but when these cease to be all-imperatively pressing, or when civilization and cultivation 
enable him to think of higher things, then, under the law of his intellect which constantly compels him to strive for the extension of his knowledge and the development of his mind, irresistibly he begins to ask-' what can I know?' And this necessarily involves the queries respecting the universe and himself which have been already stated. We may, then, safely conclude that reason demands satisfaction upon these points, and so that man has, and must have, by the very constitution of his mental nature, certain intellectual wants with regard to

\section{Theology.}

Now when he comes to solve these questions, he is, on the one hand, driven into atheism, not as the solution of the queries, but because being unable to solve them in a demonstrative way, he takes refuge in a dark hypothesis, which relieves him, as he imagines, from any further trouble about the matter. Atheism is no solution of the queries, it is a mere denial that they can be solved at all. Or, on the other hand, from the very necessity of belief in something; of something absolute, as the ground of all truth, as the basis of all ideas, as the central point from which alone all reason becomes possible, he is driven on to further queries; as, for instance, whether the universe and his own soul must not have had an origin in something superior, which must then have been intelligent, personal, will, or it could not otherwise have originated a creative act; and whether ultimately there can be more than one such originating power; and whether moreover, 
it is not necessarily true, that if there be one supreme, intelligent, self-existing cause, he must therefore be perfect; as perfect, holy; as holy, just and good; and as the Creator of man, the claimant by right of his homage and obedience. Then follow the consequent queries, whether such a Creator must not in the very nature of things, as possessing perfect reason, have a will with regard to man; whether that will can be known; whether man can acceptably serve this Creator, and how. And then irresistibly arise the facts in man's own self-consciousness, of moral accountability pointing to a moral law as the ultimate and unchangeable standard of right and wrong; that accountability itself based upon the indestructible conviction of moral choice; and that law resting in the nature, and imposed by the will of the Perfect Being. And as arise the sense of dependence, and the consciousness of imperfection, the soul will strive still upward in her grasping after the God whom she may trust, and the moral rectitude, the virtue, whose ideal perfection is the culminating point of her purest and noblest aspirations. And then as she realizes the difficulties of the path of virtue, the obstacles which impede her energies in their struggle towards the perfect good and true, as she rises to some conception of holiness and union with God, being the deepest and fullest harmony of her being, she begins intuitively to perceive that God must be the end of her knowledge, and the goal of her affections and hopes. 
Thus man becomes a religious creature; and as he continues to exercise his reason, in reflection upon the nature of God and the relations of man towards him, he finds evil existing which is hostile to God; he finds that it has introduced discord into the moral harmony of the world; he finds such a frequent and unjust triumph of evil and vice, and such depression of, and apparent injustice to virtue and good, that unless God be just and holy to rectify the wrong, nothing but inexplicable confusion reigns, which throws us back upon atheism; or, that if God, consistently with his nature, rectify the evil and vindicate right, truth and holiness, he must do so in a future life, since it is not done in this; and hence there must be a judgment, either at each individual death, or collectively, hereafter, when all will be reconciled according to that absolute equity, whose existence Reason intuitively recognizes in her conception of justice; and to which, every appeal of the helpless wronged against the tyranny of might, - of outraged innocence against audacious crime, - of oppressed virtue and truth, from the present to the future,-all bear instinctive testimony. And as in view of evil, right and wrong, virtue and vice, man possesses the ineffaceable self-consciousness of choice and accountability, Reason feels the stringent necessity of a revelation, to guide her as to the will of God, as to the path of duty, and as to the principles which will ultimately regulate that judgment, without which there can be no such thing as perfect justice, and the vindication of virtue 8 
and holiness; and if there be not, then there is nothing left again, but the revolting perplexity and contradictions of atheism. Reason, seeing that there must be a God as the absolute ground of all existence, physical, intellectual, and moral, and hence concluding his absolute perfection and sovereignty, perceives the immeasurable distance between this sovereign and man, and the subjection of the latter to the dominion of evil; and affirming, with unerring intuition, that only like can assimilate to like, she confesses, as a necessary consequence, her need of religion, to rescue man from the influence and effects of sin, and to purify and elevate his imperfect nature into harmony with the changeless fount of holiness and perfection.

We have, then, three distinct facts from the analysis of self-consciousness, which afford the most certain basis possible for religious belief, by showing that its fundamental conceptions are necessary, as essentially existing in reason itself. One of these facts, is, that the feeling of dependence, the religious element, must develop itself as a constitutional characteristic of man's nature; and that in connection with his spontaneous consciousness of accountability, it must attach itself to something supernatural, the conception of which can not be furnished by the senses. Another of these facts is, that the Understanding, in its logical processes, can not arrive at the conception of God ; since the Understanding only works upon materials which are furnished it, and nothing which it can receive, can possibly give it any conception of eternal, 
underived, absolute being. And hence we come to the other fact, that since Reason is obliged to believe in an absolute First Cause, and a perfect will identical with perfect moral law, as the necessary basis for the possibility of any existence, any belief, any reality, and any right and wrong, she finds the conception of God existing in herself as an intuitive truth, which thus possesses the very highest demonstration, in the fact of its necessity to Reason, as that which Reason can not deny without selfcontradiction.

It is true, that we get the abstract form of these ideas, through the operation of the logical Understanding upon that which is furnished by the convictions of Reason. But their evidence depends upon the intuitive conviction of their necessity by Reason itself. As is the case with geometrical truth. The abstract form of the proposition, that the three angles of a triangle are equal to two right angles, is a deduction of the logical Understanding; but the truth, the evidence upon which it rests, lies back in principles which can not be proved from without, but whose highest validity rests in the very fact that Reason is obliged to affirm them necessary. She intuitively sees their truth; she can not deny them without contradicting herself, and denying the possibility of any truth, any certain knowledge, and any valid reasoning whatever. However we may begin to awaken Reason to a recognition of what lies in her own essential laws; whether we begin from without, through the senses, or from within 
from principles already admitted by the Understanding; we must still get back to ultimate conceptions, intuitively felt by Reason to be necessary and undeniable in the very nature of things, as the ground of all reasoning and all truth. And when Reason is awakened to the idea of God, as a conception necessary by the very laws of her constitution, she is led on to conclude that he must be perfect, and that evil must be opposed to him. And as her ideas of absolute causation and perfection must find their ground in the perfect God, who alone can give them perfect realization, she feels that God must ultimately triumph over evil ; and that for her own hopes there must be a future reward for virtue, and a present Providence which preserves the universe, and prevents its harmony from being utterly destroyed by evil. There is moreover, an universal voice of humanity, proclaiming as by instinct, universal wants of a common nature; in which, Reason recognizes the echo of her own tones. Such is the universal necessity for religion; that which re-binds a nature struggling with, and alienated by evil, to the perfect source of harmony and holiness. And this is the great problem which all systems of religion strive to solve, in their rites, sacrifices, and expiations, whereby Deity may be conciliated, divine assistance obtained in the struggle with evil and the attainment of virtue, the consequences of $\sin$ be averted, and hope in futurity be secured. And it was because atheism contravened and contradicted these instincts of nature, these deductions of Reason, and 
put itself in opposition to what reason felt ought to be true, that it was not, and could not be a reply to the questions which reason felt compelled to ask. But where then, was she to seek for a reply-if not in revelation? And hence we see both that man has, and how it is unavoidable that he should have, intellectual and moral wants with regard to Religion, as well as Theology, which his reason alone can not supply or solve.

Now it appears impossible, indeed reason revolts from it as an unnatural thing, that God should have created man a natural atheist; that he should have formed a creature so wonderfully endowed with intellectual and moral attributes, and above all, with a powerful religious instinct, and a sense of accountability, and have left him with no positive knowledge of the will of his Creator; nay, with no certainty respecting that God whose existence Reason felt compelled to affirm, and after whom universal human nature in its dark struggles with evil, has ever groped and longed with an affecting and unquenchable yearning. From the sublime anticipations of Plato, to the dim gropings after the supernatural in the fetishism of the African, there is still recognised the deep cry and wail of humanity for its veiled and absent father. In the ancient science of Etruscan Augury, in the dark oracle of degraded Obiism, humanity has exhibited its indomitable and irrepressible want of guidance from God.Through the manifestations of Vishnoo, and the endless incarnation of the Dalai Lama, there gleams the impera$8^{*}$ 
tive demand of humanity for union with divinity. In short, the whole religious history of man, repels, as monstrous, the supposition that God would leave his intelligent creatures with no voice from himself, no declaration of his will. This is infinitely more absurd than to suppose that God would place man in a universe of whose existence he could not possibly assure himself; for if there be a God it is of infinitely less importance that man possess the faculty of knowing the actual existence of the outer material world, than that he should be utterly unable to know the momentous moral truths of the existence of God, and of his moral law and will. But unless we would abandon ourselves to the egregious paradoxes of utter scepticism, we must hold that we do actually know of the real existence of the objective material world, by immediate intuition; an intuition called into exercise by the senses, but as directly and necessarily affirming the existence of the material universe, as we intuitively, and directly, and necessarily affirm that the whole is greater than a part, or that two straight lines can never surround a portion of space. And thus too as God has revealed to us the material universe, through our sensational and intellectual intuition, which gives us direct and actual knowledge thereof, so has he revealed to our reasoning and moral intuition the certainty of his own existence, and of moral truth; and it is to that intuition we are to look for a fuller knowledge of spiritual things. That is, that in proportion to the development of 
the faculty whereby we directly or intuitively perceive moral and religious truth, so will we perceive in ever increasing degree, the truths which God has revealed to us. And herein does christianity astonishingly differ from every other professed revelation, in not only appealing directly to this intuitional faculty in man, whereby he can test, from his own consciousness, its adaptedness to his intellectual and moral nature; but at the same time it enlightens and elevates that faculty itself in its spiritual perception, to lay hold of the truths which christianity reveals, and to find the sphere of Reason enlarged beyond what its natural power, unawakened by christianity, could reach. Thus, for example, we might have no conception of the full powers of our vision, nor that they can reach beyond the narrow, mount-encircled, and cloudy valley in which we stand; but when we are taken and elevated to the summit of the mountain ridge, and the atmosphere is cleared and purified, we find our visual powers piercing far into infinity. Yet did we not actually possess the powers themselves, it would be vain to tell us that there was a noble prospect, such as we had never conceived. We might believe the words,-we could have no possible conception of the thing. So, likewise, revelation elevates our intuitional Reason, and clears our spiritual perception; but without the antecedent conceptions, (however dim and deeply lying, however needing to be awakened and illumined,) whereby we can understand and perceive the truth of what reve- 
lation affirms, it could only give us unintelligible words ; we might believe that in some sense they were true; we could attach to them no signification. But possessing the corresponding conceptions, with every increase of light, our faith would acquire a firmer basis, as we perceived that revealed truth rested upon principles necessary to our Reason and Moral Nature by their very constitution. 


\section{H A P T E R 11.}

BASIS IN THE NECESSARY CONCEPTIONS OF REASON FOR BELIEF IN INCARNATION.

Having endeavored to show that man must have intellectual and moral wants with regard to religion, which can only be adequately answered by Deity himself, we shall in the next place endeavor to show how alone a revelation or manifestation of God HIMSELF in the world's history could be possible.

When we say that under certain conditions alone could a manifestation connecting God himself with the noral history of mankind, be possible, we do not limit the divine power, but speak as to the demands which reason must make in her limited human sphere. That Deity could have constituted things, and the nature of human reason, differently from the conditions under which they actually exist, is not here questioned. It lies entirely out of the scope of our present investigation. But Deity having created us under certain finite conditions, bound by certain laws, then, in view of this constitution, it is proper to say, that certain things are or are not possible. For example, finding with what nature Deity has created 
body, it is no limitation of his power to affirm absolutely that two bodies can not occupy one and the same portion of space at the same time. Indeed we are compelled to affirm this by the very laws of that Reason which Deity has himself constituted. When then we affirm that only under certain conditions could a revelation or manifestation of God himself in the world be possible, it is the same as saying, that Deity having constituted human Reason in a certain manner, it was impossible for him to reveal himself to it as so constituted, except under certain conditions, rendered necessary from the very nature of things. For it may be safely and certainly assumed as a fundamental principle which no arguments can overthrow, that whatever contradicts the conclusions which Reason by her own laws is necessitated to make, must be false. It contradicts God himself, who by those laws has imposed upon Reason the necessity of such conclusions. This is self-evident when applied to the simpler conclusions which flow from those laws; as, for instance, no species or amount of argument can prove that man does not think, or that a part is greater than the whole, or that body has no dimension, because such propositions contradict the necessary affirmations of Reason; and if they were not necessary, and consequently universally valid, there could be no knowledge, no thought, no reason. The same is equally true (for the same reason,) if not so evident at first sight, of the more complex conclusions flowing from the laws of Reason; as, for instance, no 
argumentation could prove that the square of the hy. pothenuse is greater or less than the sum of the squares of the other two sides; and hence it is no irreverence to affirm that the constitution of things and the laws of Reason remaining what they are, it is impossible for Deity himself to deny or disprove these truths. Indeed, this is the highest reverence which we can pay to Grod, to affirm that he is immutable, and therefore to be fully trusted, and that he can not contradict himself in truths which necessarily flow from the laws which he himself has established. Thus, we trust the way has been cleared from misunderstanding for our advance to the position that a revelation or manifestation of God HIMSELF to be an objective fact for all mankind, uas impossible, except under certain conditions necessarily demanded by Reason.

Having arrived at the logical and moral necessity of the existence of a supreme, unoriginated, perfect Being, reason must stop with the idea, and from it alone can not possibly learn whether it has any absolute existence, or any thing whatever concerning it, except what she can deduce from her own processes. Such idea, it is true, affords a valid ground for morals, because Reason is obliged to assume its necessary and actual existence; but still it can only have a subjective validity-that is, it exists only in and for the Reason itself, and without revelation or manifestation, can never become an object of knowledge. There can be no knowledge without objects of knowledge; and nothing can be an object 
of knowledge, which is not the object of actual or possible experience; whether that experience belong to the senses, or to an internal intuition. That there is an external sense, is evident from its giving us experience of external objects; and that there is an internal sense, is equally undeniable from our experience of states of our own soul. Intuition can only refer to objects of knowledge, as given us by Experience; and to this intuition, Understanding refers for thinking those objects, as far as they are given. There can be only two sources of human knowledge; namely, Sensibility (including the external and internal sense,) and Understanding; through the first of which, objects are given to us, and through the second they are thought by us. Such objects we can only know as phenomena; that is, by the effects which they produce upon us through Sensibility. Should we be even able to know the substance of such objects, immediately in itself, without the intervention of phenomenal effects, it is evident that this would not affect our argument, since such knowledge could only belong to a direct intuition, and could only possess objective validity for human reason collectively, so far as such intuition belonged to universal humanity. Nothing, then, can possess an objective reality for mankind, which can not be given for all; that is, whose representation can not be referred to universal actual or possible experience; as, for instance, "a fragrant flower," or "the heavenly bodies," known by their phenomena through the external 
sense; or "the whole is equal to itself," or "a perfect triangle," represented as possible phenomena through the internal sense; or "the eloquence of Demosthenes," known by the internal, intellectual, and asthetical complex phenomena experienced from perusing him. Or, in other words, we can only know through the experience furnished by the external sense, or the experience furnished by the internal. This experience can only arise from phenomena of objects affecting either sense, or from something already in the sense itself; because, from the very necessity of every thing reaching us by effects produced upon this Sensibility, we can only know objects by those effects. In no other way can we describe them, as we would be able to do, could we know them in any other way; and could we know them in any other way, we would possess a faculty wholly different from any human one; and we would thus be other beings than men, as soon as we passed out from the laws and conditions which define the nature of human intellect. Intuition, then, represents the objects thus given by Experience, as objects of immediate intellectual perception; and Understanding receives these objects as elements of thought, or thinks them; and thence Conceptions arise. All our knowledge, then, must begin from Experience, (which only gives us phenomena,) and from it must our faculties be awakened into exercise. It will be necessary then to perceive what are the conditions by which alone we can obtain any experience or conception of phenom- 
ena, or compare our conceptions as elements of ratiocination.

Upon analyzing the manner in which phenomena are given to us by the external sense, we find that we can not only represent them as external to us, but also in shape, quantity, and in certain relationships to each other. And in like manner, the experience given us by the internal sense, can be ordered in determinate succession. But also we find that something not derived from phenomena, lies beneath the possibility of these representations; and when we examine how we can represent phenomena in the manner stated,-which is yet absolutely necessary, or we could not represent them at all,-we find in the Sensibility itself a representation or sense of the existence of space and time, which are not derived, but are intuitively conceived, as the necessary conditions by which alone we can perceive, or represent to ourselves phenomena and their relations.

These conditions are à priori necessary, because we do not derive them from experience, and we find them always, and unavoidably, lying beneath the very possibility of experience. We can not conceive, or possess any experience of, phenomena, without there being involved the conceptions of relation and succession; and the very possibility of these lies in the à priori intuition of Space and Time, which represent no property of things, but are the conditions by which alone we can represent to ourselves the existence of things. We may imagine 
no objects as existing where they once were, but the conception of space still remains; we can not get rid of it; we can not possibly imagine its removal. And it is evidently no property of things, for it can only be conceived as one. Figure it divided by objects, yet it is only one and the same Space which is divided, as we immediately perceive when we abstract all conception of objects. In the same way of Time; the abstraction of objects does not destroy its conception, and the succession or division of time is the limitation of one time lying at the foundation of all conception of succession, simultaneousness, or change.

These, then, are absolute conditions imposed upon us by the laws of our intellect, under which alone we can perceive or represent to ourselves objects of knowledge. That which could not be brought within these conditions and modes of conception, could never become known to us, because it would lie beyond the possible sphere of our knowing. And so necessary and fundamental are they, that is, by their lying beneath all else in our intuition, that even the conception of truths in geometry and physics become possible for us. And more than this, it is only by means of these intuitions, that we can perceive our own existence as successive and continuous, and as distinguished from an external world which is not a part of us. We can not even conceive of our present existence, except as in Time and Space.

But should it be held, moreover, that there is something perceived by intuitive Reason, independently of Ex- 
perience; that there are certain truths which Reason is able and obliged to assert independently of, and before, all experience; that their validity lies in the fact that they are universally and necessarily true, that Reason is abliged to affirm them by her own laws, and that they do not come from without; it must still be evident that this is not involved in our argument, since Intuition is only able to represent them as possible phenomena, because the conditions of the Sensibility itself lie beneath them. Should Intuition thus be held to possess some ungiven principles $\grave{a}$ priori, which are a part of itself, yet their conception and use by the Understanding are only possible, by their falling under the same conditions which alone make any experience of phenomena possible to us. And thus limited as human intellect is, by certain laws of its nature or constitution, as necessary conditions of all its knowledge, it is only by coming within, or under these conditions, that God can reveal himself in the world as an object of human knowledge.

It is not to be denied that God could, or even does, reveal his existence or will to the Reason, by the mode of this $\grave{a}$ priori Intuition; but it is evident that such revelation can only possess a subjective validity, and that $\mathrm{He}$ himself, as immediately connected with man's moral history, can not thus become an objective truth for all men. And if such a revelation was even supposed in every individual, it would then either become like those necessary truths which are held to spring from Intuition, and 
would thus be an original property of human intellect, as which, it must after all, fall under the conditions which we are to prove a revelation of God himself, must fall under to be possible; or, if conceived as otherwise revealed to Intuition, through the internal sense, before it could receive external expression, it would be necessarily so modified by the varying experience of every man, (a diversity unavoidable from the variety of causes which affect the individual character and mind, and which modify the external expression of its internal experience,) that the revelation itself must become an object of scientific investigation, which must settle what was the universally valid in the diversity of individual representations, before it could fulfil the character of a revelation, in being an authoritatively valid object to all men alike. Now, since it is not pretended that God has actually made a complete subjective revelation to every individual,-which would virtually supersede the necessity of christianity as an objective revelation,-it is clear that any partial revelation, made only through individual intuition to a few, could only be valid for those, not the subjects of such intuition, who scientifically, or otherwise, saw reason to receive the individual representations as revelation. But a revelation intended to manifest God himself connected with the moral history of the world, in a manner which should be objectively valid for all men, must evidently proceed in another manner. It must become an object of knowledge for human reason uni- 
versally, and it must propound what does not contradict that universal reason, and what is strictly applicable to universal human nature.

Since then, we can only know phenomena, and these only under the necessary conditions of space and time, it is impossible for us to know the infinite and unconditioned; and hence it would be impossible for God to reveal himself to us as an historical object of knowledge in the world, except by the sole means of becoming to us phenomenon in space and time.

But phenomenon, which can alone possess universal validity, must belong to the universal system of phenomena in nature, and fall under their laws; that is, it must be an object of possible or actual experience, conditioned necessarily as such by Space and Time, and hence referable to adequate causes. It is not necessary that such phenomena possess a permanent existence for the senses of all men in all ages; but in order that they may be susceptible of proof to the intellect of all men in every succeeding age, it is necessary that they should have BECOME,- - that they should have taken their place in the general system of phenomena, in the manner in which phenomena do assume their place in the world; that is, by BEComing (naturans,) or, in other words, by a NATURE; that is, by birth into, and consequently under the conditions of the phenomenal world. For in no other way can we recognize the truth of facts. Logical truth is the correspondence of our knowledge to the object of con- 
ception. But, as has been already said, our conceptions can only arise from the materials furnished by the Intuition to the Understanding, which Intuition receives its objects from the experience of Sensibility as affected by phenomena, except in the representation of Space and Time,-which lies in the Sensibility itself,-and in those à priori necessary truths, (if they be admitted,) which are independent of experience, but must, nevertheless, be conceived under the conditions of Space and Time, as objects of possible experience.

If, therefore, the object of what is affirmed, can not be phenomenon, or an object of possible or actual experience, it is impossible for the judgment to pronounce upon its truth. It may be true, but it can never be proved, because it can not fall under those criteria by which alone the human intellect can test the truth.Hence a fact to be true for all men, must either be present phenomenon for all men; or, to render testimony respecting it as truth, valid to those to whom it is not present, it must have fallen within the system of phenomena respecting which, alone, the judgment possesses any criteria to pronounce as to truth; that is, it must have become, or passed into nature, whence alone we can obtain any objects of conception, to which knowledge can correspond. Or, in other words, it must have become such a fact, as from the nature and laws of intellect men were competent to testify to.

And here, to obviate a possible objection at this stage 
of our statement, it is to be observed, that we are not settling the nature or amount of testimony which may be requisite to substantiate a given point, but we are showing what facts alone, from the nature of intellect, can fall within the sphere of testimony. For example, if the given fact be the raising of a dead man to life, it falls within that sphere, because it is something which to be an object of testimony at all, must become, or come within the range of phenomena from which conceptions can arise, and which thus possesses a nature; [that is, it is a (phenomenal) object of possible or actual experience, conditioned (necessarily) as such by Space and Time, and referable to an adequate cause.] But if the given fact be, that one has seen God as infinite spirit, (and hence, by the very force of terms, unconditioned,) it admits of no testimony; because from the very constitution of the intellect, it is an impossible fact, since it can not fall under the conditions of space and time, under which conditions alone we can perceive or conceive any phenomena.

Now from Spiritual Being we can not separate the conception of life. Nor can it be questioned or doubted by reason, that in God existence and life are, and must be one. We have now nothing to do with how life exists in an infinite, unconditioned Being; nor with what life is in any being at all. We can not know objects (and hence life as an object, ) in themselves, but only by their effects ; that is, as phenomena. God himself, then, as becoming directly connected with the moral history of 
humanity, can not be a living, historical object of knowledge to the world, except as manifested in nature, or as living phenomenon under the conditions of space and time. We have, then, to do with the question, and we can not avoid it, how life manifests itself, or what are its phenomena? The entire range of nature demonstrates that the idea of life involves that of a complex law, necessarily involving unity in complexity. In all the operations of nature, law necessarily must contain the principle from which unity in its developments arises. The very conception of a law of nature, involves a principle of unity without which it could be no law. Now in all the developments of life in nature, from vegetable life up to the highest form of animal, there is evidently and necessarily a principle of unity in each species of life, and in the life of every indıvidual of each species, which gives harmony, and even possibility, to the development and operation of the complex functions springing from the fundamental law. Life universally developes itself by and in organization, and it is the unity of the fundamental law which harmonizes and directs every complex operation; so that the diversity of leaf, branch, trunk, or of limb and other organs, with their complex and rarious operations and functions, yet constitute one tree, or one animal, in which every part and every operation is harmonized by the formative law into a consistent whole. As we can only know this law of life by its phenomena, and not in itself, it must manifest itself to us through 
organization, or we can not know it at all. It is only in that manner that its phenomena can be exhibited to us. But unity of organization itself necessarily implies "individuation." Life, as a phenomenon of objects, must develope itself in individuals, and as phenomenon of rational objects, in persons. A living, rational object in the history of man, connected with the development of humanity, must appear as an individual person in space and time, or it can occupy no place in the moral history of man, since its life and personality, if not appearing in that manner, would be merged and lost in the general impersonal life of humanity, and thus it could not be an object of knowledge and testimony. If, then, God would reveal himself to man as a reasonable, living object of knowledge in the world's history, he can only manifest himself as organized Being in space and time; that is, by becoming, or being born (naturans) as it were, into the phenomena of nature, so as to be a fact in the world's history, capable (as any other such fact must be, to be an object of knowledge and belief, ) of reasonable and logical testimony. In other words, he must become incarnate.

God in this manner accommodating himself to the constitution of things as he has established it, could thus, introducing himself immediately into the consecutive chain of events which form the history of the world, introduce a new element into the moral and social condition of the world. A single mere extraordinary interposition could never affect the laws which regulate that condition, unless 
indeed to change them violently. But springing as that condition does from the interdependent events which make up the history and development of the life of mankind, that which is to exert a permanent influence upon all succeeding ages, must itself enter in and belong to those connected events, which, as historical, have possessed an objective existence, operating upon and modifying succeeding consecutive events, and thus forming the chain of naturally connected causes, whence civilization and politics have been developed. A mere mediately declared revelation could never itself belong to or enter in, but would be quite apart from such class of events. The prevalence, however, as accepted by many, of a religious system based upon such revelation, would become a historical fact, but it is evident that in this manner God himself could not have become immediately connected with the class of events in question. And the point in view is not what God might have done, but how alone he could himself enter into the connection of events.

Reason perceives also another collateral necessity for God becoming incarnate, if he would reveal himself in the history of the world for moral ends, and for the introduction of new elements into the religious, and social condition and civilization of man. It is, that as the universal religious problem of humanity is, how the finite nature may be brought into reconciliation and connection with the infinite; how the chasm, which in the very nature of things must necessarily exist between the im- 
perfect and erring, and the Perfect and Holy, between Man as he is, and God as Reason perceives he ought to be, may be bridged over ; it is absolutely necessary, for the resolution of this problem, that there be a real Synthesis; without which, while the general laws of the Universe are not violated, the Diverse can never be brought together. And it requires no analysis of the nature of synthesis to perceive, that whether the fact has ever occurred or not, yet the Unity of the Diverse in divine and human, must be at once God and Man.

When, then, christianity affirms that this synthesis has been furnished, and that God has manifested himself actually, we see at once in the necessary conceptions of reason, not only the possibility and reasonableness of such doctrine, but even the absolute necessity of it, if God should ever immediately manifest himself in the moral history of the world, without utterly changing the constitution of Reason and of the universe. If he has never thus revealed himself, he is still, in some measure, an unknown God; and his will, as alleged by mediate agents, can only be so far valid, as we satisfy ourselves that they could have been informed respecting it. But if God has thus manifested himself, he must have done so, as we have seen by incarnation-by becoming (or naturans) into the system of the phenomena of nature; and hence, in that incarnation, would become an object of knowledge in the world's history, and thus, also, have been a legitimate object of testimony, and in 
this manner the actual objective reality of the manifested existence of God in the world's history, would be a valid fact for all coming time, and all succeeding intellect. And although we must satisfy ourselves of any evidence pretending to substantiate such incarnation, just as we must satisfy ourselves of any evidence alleged for a mediate revelation through a Prophet or Angel; yet there is this essential difference between the two facts, that the latter could only give us certain declarations from Grod; while the former, if it ever occurred, would, by connecting Deity himself immediately with humanity, place the whole human race in a radically different relation towards God, and thus absolutely and actually change the moral position of mankind irrespective of any belief or disbelief in incarnation. For as every event and every individual in the chain of facts which make up the history of the world and the development of humanity, is influenced by every preceding link in the chain, so that if any one fact had been different, the whole succeeding train of events would have been modified; in like manner, every link influences the whole consecutive chain in its own appropriate degree. Thus the introduction of so important a link as God himself, would incalculably influence, modify, and change the whole succeeding course of history and position of humanity, whether that entrance of God into the established order by which humanity is influenced in its historical and moral development, be believed or not. 
As far as we are able to see, the objections of any force, which might be advanced against what has been said, are the three following, which we shall endeavor to obviate in order:-First, that the principles upon which the argument is constructed are erroneous: $\mathbf{S e}$ cond, that the reasoning is, itself, inconclusive, even admitting the premises; and Third, that the whole argument amounts to a mere elaborate and obscure way of stating a common truism, which makes nothing for the doctrine maintained.

As to the first objection, it seems sufficient to reply, that although we have taken no pains to conceal or disguise our own metaphysical views, yet the argument is expressly constructed upon three grounds, which may be safely admitted by any metaphysician. While we have endeavored to show that the conditions of Space and Time under which we are necessitated to perceive phenomena, are conditions lying in the original forms of the intellect itself, yet it is impossible for us to conceive how any one can dispute that they are necessary conditions of all perception of phenomena, whether simultaneously springing from experience of phenomena themselves, or absolutely antecedent as the very condition of all possibility of experience. Hence it seems undeniable, upon any theory whatever, that an object of knowledge must fall under the conditions of Space and Time; or that an objective fact can only become historical or capable of testimony, by becoming realized 
in Space and Time. If, again, the principle be denied, that personal life can only possess an objective historical validity in the life or history of mankind, by incarnation, that is, by manifestation as organized Being, it evidently lies with the denier to show how then it can be possible. For if nothing can be an integral part of the objective history of man, without necessarily, as such, being an object of knowledge in Space and Time, then a person can not so be connected with and enter into that history, except by coming under the same conditions; in which, if its personality be preserved, and be not merged and lost in the general life of humanity, it must then appear as individual organized Being. And as the principle is perfectly consonant with the universal convictions and conceptions of men, and is, indeed, derived therefrom, it may be justly employed in argument, until some clear confutation is produced which will explain how a person can otherwise possess a place in the history and development of human nature.

With regard to the third principle, which forms a ground of the argument, it is sufficient to observe that the law of Synthesis, that is, the Union of Thesis and Antithesis being indifferently of the nature of either, is of almost such axiomatic validity, that we are willing to leave its truth to the suffrages of clear and scientific thinkers. If the grounds, then, of our argument, be not considered as absolutely conclusive, we think it must be admitted that they rest upon such a strong appeal to 
reason, as to obviate the objection that they are either weak or absurd.

But we pass to the second objection, that even admitting the grounds of the argument to be correct, yet the reasoning based upon them is inconclusive. Of course the value of the argument must stand or fall, as it is able to commend itself to each one's reason. To some it will doubtless appear less satisfactory than to others. But to judge it properly, it is necessary to keep clearly in mind what is its object, and what the limit within which it pretends to possess any force. If it be conceived as undertaking to establish that which it was not meant to affirm, it will be certainly misjudged. It becomes necessary, therefore, to state definitely its precise aim. It was not designed to prove the incarnation, but to show that in affirming such a fact, christianity uttered nothing absurd ; that whether the incarnation had ever taken place or not, there were reasonable grounds for believing in the possibility and propriety of such an event. If a person can only appear in the history of man, and connected with the events of that history, by manifestation as an object of knowledge in organized Being, then the divine person in so appearing, must necessarily be objectively manifested under the conditions of Space and Time, as a real Beings capable of historical testimony. And if the great moral problem of all religions, of humanity itself, as to how the divine unconditioned nature could be actually united with the human finite nature, was to be resolved 
once for all; then once for all must there be a synthesis of the two, a point of contact, of real union, God and man actually one. If God as a person would come down into the moral history of humanity to unite it with himself, and this in a way which should make the synthesis an objective fact, capable, as a part in man's history, of legitimate testimony, and as a link in that history of an influence for all ages, then he could only do so, as far as we can conceive, by incarnation. So that if the argument be inconclusive, it at least rests upon such philosophical views of the nature of things, the laws of the universe, the nature of man, of personality, and of history as the development of the life of man, that it can not be summarily dismissed as either shallow, unreasonable, or unnatural.

The third objection, as we conceive it, would be this: that the pretended argument is only an affirmation that if God manifested himself in human nature for the purpose of uniting that nature with his own, he would do so by incarnation, which is the mere identical proposition, that if God became incarnate in human nature he would become so by incarnation. We think such an objection would be unfair, as well as false, because it would overlook the very scope of the argument. This may be inconclusive, it is not formed for convincing any one that there has been an incarnation,- - this, as far as christianity is concerned, must be settled by our estimate of the character of Christ; but the true value of the argument, $10^{*}$ 


\section{BASIS IN THE NECESSARY CONCEPTIONS, ETC.}

(and whatever be thought of its force, this in all fairness must be conceded to its object,) is, that it endeavors to start from principles whence it may be rationally deduced that, if God, without violently changing the laws of the universe and the nature of man, would bring his own personality into connection with the moral history of humanity, he would be expected to do so by assuming or entering into that humanity by incarnation; and thus any antecedent difficulty of reason in conceiving of such an event, should it ever be proclaimed, would be obviated, and a rational and moral ground be obtained for belief in the fact. 


\section{CHA P TER 111 .}

THE GROUNDS OF THE PROBABILITY OF MIRACLES, ANT THE SUGGESTIVE BASIS IN REASON FOR BELIEF IN PLURALITY IN DIVINE PERSONALITY.

WE endeavored to show in the last chapter, by an analysis of the laws which condition the intellect in its perception of objects, that Deity could only manifest himself as an object in the world's history, by incarna tion, and that this would become a legitimate object of testimony. Such testimony must embrace the essential point, that God-manifest, or incarnate, was consistent in every respect with himself; that is, that he displayed the moral character, or attributes of God, in a humanity whose character was perfect, as it must necessarily have been in the synthesis of human and divine. In other words, as the being and attributes of God, as deduced by Reason from her own necessary conceptions, must be the basis of belief in revelation, the revelation must not contradict, but be consistent with them, however much further it may lead on Reason, beyond where she was able naturally to reach. Now, as the christian revelation embraces the occurrence of miracles, it is necessary first 
to establish that a miracle involves no contradiction to the laws of Reason, and can fall within the scope of her judgment. The true province of miracles, we would remark, in passing, would be, in the case of God manifesting himself, to show the submission of nature to the Supreme Power, whose will pervades the universe; and in the case of human agents, to exhibit necessary credentials of their commission from God. Hence, in these two cases, a manifest difference would be found to exist between the two classes of miracles; a difference, which to the philosophic eye, looking beneath the mere surface of the christian records, is amazingly striking between the miracles of Christ, and those of his Apostles. While, then, under certain circumstances, miracles might be necessary as credentials of those commissioned by God, we should fall into most dangerous misapprehension of their true province, did we not keep in mind the essential fact, that the doctrine was the test and proof of the validity of the miracle. For, if the miracle was to be the proof of the doctrine, we might find ourselves involved in inextricable moral confusion, unless we could distinctly prove that the powers of evil could under no possible circumstances produce miraculous effects. A point we might assume, but which assuredly we could never prove. The relation, then, in which the miracle stands to doctrine, is that of a credential to scientific skill; as a man might be obliged to show a diploma to secure a hearing for his claim to the title of physician; 
but his scientific knowledge must be the test of the validity of the diploma, and that perhaps it was not even forged. And, as his possession of science being established, he would not be required to be perpetually exhibiting his diploma; so, the doctrine being placed in a commanding position, addressing itself as established truth to universal reason, and so placed as to invite and submit itself to the judgment of reason, as to its soundness and consistency, miracles would be no longer employed, but would disappear from the stage.

We proceed, then, to notice the most formidable objection to miracles which has ever been started; and one, which although entirely illogical and fallacious, has deceived even some very acute minds, and one no less penetrating than Mr. Hume's. His objection was, that no testimony could substantiate any thing contradictory to experience, or at variance with laws of nature; and hence that no evidence can prove a miracle. His principle or premiss from which he argued, is perfectly sound, harmless and obvious. It is extraordinary, says Mr. J. S. Mill, that it should ever have been considered dangerous or profound. The non-sequiter, as he applied the principle to miracles, it is possible to exhibit in no very extended compass of remark; and in so doing, we shall condense and employ the language of the profound logician who has been already named.*

* J. S. Mill, author of "Inductive Logic." 
An error, too, should first be adverted to, into which some of the most distinguished controverters of $\mathrm{Mr}$. Hume's doctrine have fallen, and among them, the celebrated Dr. Campbell himself; that is, overlooking the difference, or conceding that none exists, between improbability before, and after the alleged fact. It may be a matter of the very highest degree of improbability to us, knowing, as we do, the constitution of Turkey, that the Sultan would ever visit the United States. We may pronounce it morally impossible, and not only doubt, but possess a positive disbelief that it could ever occur. But the testimony of respectable individuals,-nay, the general testimony of the public prints, would be a sufficient ground for our believing that he is now actually in the United States, although he may depart again without our having ever seen him, or even any person of our acquaintance who actually had. The moment that the fact becomes the object of legitimate testimony, its improbability is greatly different from what it was antecedently; and the ground of disbelief must then lie in a comparison of the testimony offered in the affirmative and negative. "What would be really contrary to experience, would be the assertion that the event had happened more frequently in some large number of times, than the same combination had ever been known to occur in that number of times; and this alone it is which is improbable, in the sense of incredulity, or, as we have called it, improbability after the fact." 
'The positive evidence produced for a fact, which is yet rejected as impossible or improbable, is never such as amounts to full or demonstrative proof. The witnesses may have been mistaken; their senses may have been deceived; and hence the testimony or proof as to the real nature of the phenomenon, is an inference grounded upon an approximate generalization. All, therefore, will depend upon the evidence in the negative. If that also rests upon an approximate generalization, it will be a case for the comparison of probabilities. And if this latter evidence approach nearer to universality than that in the affirmative, then the fact is to be provisionally disbelieved.' "If, however, an alleged fact be in contradiction, not to any number of approximate generalizations, but to a completed generalization, grounded upon a rigorous induction, it is said to be impossible, and is to be disbelieved totally." Thus "Hume's principle that nothing is credible which is contradictory to experience, or at variance with laws of nature, is merely this very plain and harmless proposition, that whatever is contradictory to a complete induction, is incredible." "But it may be objected, that it is a petitio principii to assume that an induction is complete, when a fact supported by credible evidence, presents itself in opposition to it. To this it is a complete reply, that whenever the induction can be complete, we have a right to reject what contradicts it. We have the example of complete induction in the case of causation.' "If an antecedent $A$, super- 
added to a set of antecedents, in all other respects, unaltered, is followed by an effect $B$, which did not exist before, $\mathrm{A}$ is, in that instance at least, the cause of $\mathrm{B}$, or a necessary part of that cause; and if $A$ be tried again with many totally different sets of antecedents, and B still follows, then it is the whole cause. If these observations or experiments have been repeated so often, and by so many persons, as to exclude all supposition of error in the observer, a law of nature is established, and so long as this law is received as such, the assertion that on any particular occasion $\mathbf{A}$ took place, and yet $\mathbf{B}$ did not follow, without any counteracting cause, must be disbelieved." "The general truths, that whatever has a beginning has a cause, and that when none but the same causes exist, the same effects follow, rest upon the strongest inductive evidence possible." "And since the law was received on what seemed a complete induction, it can only be rejected on evidence equivalent; namely, as being inconsistent-not with any number of approximate generalizations-but with some other and better established law of nature." "We can not admit a proposition as a law of nature, and yet believe a fact in real contradiction to it. We must disbelieve the alleged fact, or believe that we were mistaken in admitting the supposed law."

"But, in order that any alleged fact should be contradictory to a law of causation, the allegation must be, not simply that the cause existed without being followed by 
the effect, for that would be no uncommon occurrence; but that this happened in the absence of any adequate counteracting cause. Now, in the case of an alleged miracle, the assertion is the exact opposite of this. It is, that the effect was defeated, not in the absence, but in consequence, of a counteracting cause ; namely, a direct interposition of an act of the will of some being who has power over nature; and in particular of a Being whose will having originally endowed all the causes with the powers by which they produce their effects, may well be supposed able to counteract them. A miracle, (as was justly remarked by Brown,) is no contradiction to the law of cause and effect; it is a new effect, supposed to be introduced by the introduction of a new cause. Of the adequacy of that cause [of such Being as has been supposed] if it exist, there can be no doubt; and the only antecedent improbability which can be ascribed to the miracle, is the improbability that any such cause had existence in the case."

"All, therefore, which Hume has made out, and this he must be considered to have made out, is, that no evidence can be sufficient to prove a miracle to any one who did not previously believe in the existence of a being or beings with supernatural power ; or who believed himself to have full proof that the character of the Being whom he recognizes, is inconsistent with his having seen fit to interfere on the occasion in question." It is undeniable that such proof can never be obtained. The ex- 
ternal evidence, then, of a miracle, can only be invalidated by counter evidence in the negative.

If Christ was God manifested, he could undoubtedly have wrought miracles, and empowered others to do so; if he was only a delegate sent by God, the testimony to his having wrought miracles, must be countervailed, by proving the falsity of the witnesses; or, that the alleged facts were not miracles, but effects of existing causes. The antecedent probability, is altogether in favor of the affirmative; that if God revealed himself, or sent a delegate to introduce, by the declaration of his will, a new element into the moral condition of man, he would introduce new effects, by corresponding causes, into the general law of causation; that is, facts or effects springing from the immediate intervention or operation of his will, or, in other words, miracles.

The historical account of the origin of christianity, is contained in the Gospels; and, that we are warranted in receiving these books as true history, on grounds equally valid, at the very least, with those upon which we unhesitatingly receive the writings of Thucydides, and Julius Cæsar, may be left to the proofs abundantly and satisfactorily set forth in numerous works on the subject. The hyper-sceptical and fanciful theory of Strauss, destroys itself by proving too much ; for it invalidates all history, all testimony, and all possibility of making authentic historical records. An impartial investigation, conducted upon the strictest principles required by the canons of 
evidence, can leave no doubt respecting the life of Christ, and the honesty of the writers of the Gospels. It is, then, by an analysis of the life and character of Christ, that we are to test the point whether he was incarnate God.

Before proceeding to this interesting part of our discussion, we beg the indulgence of the reader, while we briefly review the ground over which we have passed, up to this point. Our fundamental problem was to find the basis for all religious belief. No revelation could appeal to us, except upon the assumption that we already possessed the idea of God, however dim and imperfect, yet capable of being developed and elevated. All arguments for the being of God, drawn from the objective universe, presuppose our possession of the power of conceiving a First, Intelligent, Absolute Cause. But such a conception we could not construct, without ideas which can not be derived from experience, and which must, therefore, already lie in the forms of the intellect itself. No written or preached revelation, no argument addressed to the understanding merely, could by any possibility give us the idea of God, unless we already possessed certain necessary conceptions whereby to comprehend the idea presented. But whence do these conceptions arise? No experience can give us the conceptions we possess, of the Unconditioned, the Infinite, the Perfect, the Self-existing. Moreover, we find in ourselves the imperative necessity of believing in something ultimate 
and absolute, whether it be the universe itself, or chance, or necessity, or Deity. But we find also in our inmost consciousness, the recognition of self, the idea of power, and hence of causation, inseparably connected with will, and the indestructible conviction of accountability, based upon moral freedom, and the idea of right and wrong. And combining these necessary conceptions drawn from the inmost depths of our own consciousness, with the ideas of the Absolute, the Perfect, the Self-existing, we are able to conceive a Personal, Omnipotent Creator and Lawgiver, and to find the idea of God enshrined in the necessary convictions, in the very constitution of reason herself. And it is this impress, this original revelation of himself, in the very construetion of the human intellect, which renders possible, credible, and intelligible, an objective revelation from God.

But more than this, man possesses a powerful religious element in his nature, which impels him to seek after the Deity, to look out of himself for absolute protection and hope, to rear his sacred altars, and to strive for union with the divinity. The solemn and absorbing problems of this vast universe, its signification and its end of man's own soul and everlasting destiny, make him long for a manifestation of the will of God, and a revelation of the truth. And the dark and awful mystery of evil, casting its dread and murky shadow between conscience and the Judge Supreme, extorts from humanity the mighty and inextinguishable cry for help and salvation: 
The whole religious development of man, is an instinctive effort to solve the imperative problem of how the fleeting, the changing, the weak, the erring, the human, can be united with the fixed, the absolute, the eternal, the true, the divine. The absolute and ultimate problem of all religion and all philosophy, is to find the true synthesis of the imperfect and the perfect, of the sinful and the holy, of the finite and the infinite, of creation and the creator, of man the microcosm of the universe, the crown of nature, and God the original of the finite type, the author and the end of all existence. And in striving after the solution of this mighty problem, the aberrations of man have incontestibly demonstrated the necessity of revelation. For, on the one hand, he has ever merged all spirit, all hope, in a mighty pantheism of nature; and on the other, absorbed all the universe, all personality, in a vast subjective idealism; while the beliefs in oracles, in auguries, in the extraordinary incarnations, which have characterized the developments of the religious element, ever seeking to attach itself to the supernatural, are so many wondrous manifestations of an instinctive conviction of what the great synthesis must be. It is like a mighty voice of humanity, calling upon the unknown God to come into his world; to manifest himself in nature ; to show that he lives in all, and all in him, while yet he is not confounded with his universe; to enter into the moral history of the world; to connect himself with humanity, and yet preserve the personality of divine and 
human; to reconcile the thesis and anti-thesis of God and man. And when christianity, gathering up all these fragmentary and conflicting hopes, these dim prophecies of universal humanity, reconciles and explains and answers them in the glorious light of the crowning synthesis which she reveals, awakened reason, seeing into her own wondrous depths by the divine illumination, perceives that by her own indestructible laws, she is compelled to affirm, that God indeed could only have solved the problem by incarnation.

The necessary conditions under which alone we can perceive any object of knowledge, are Time and Space. "We can not conceive"* any object "at all, except as it exists in space; and although we may require to be brought into contact with" an object, "prior to our forming the conception of space, yet logically the former must be posterior to, because it involves the notion of, the latter." In the same manner with regard to time, "if you take away the notion of duration, no succession is possible, inasmuch as all succession implies continued duration between the points of consciousness, just in the same manner as body implies continued space between the atoms of which it is composed. Time and space, therefore, are à priori intuitions, which are absolutely necessary as elements in all our experience. The former gives us the sphere of all inward, the latter of all out-

* See Morell's History of Philosophy. 
ward observation; time being that in which all the flow of our thoughts must take place; space being that in which all external objects to our perception must exist." Moreover, as we can only know objects by their phenomena, as affecting our sensibility, we can only know life by its phenomena, which are ever developed only through organization. If, therefore, God would reveal himself personally connected with the moral history of man, as a living object of knowledge, he must do so as organized being in space and time. And if he would do so, to enter into the world's history, to unite the human and divine, and to introduce new elements into the moral history of man, he must do so as organized being incarnate. The necessary laws of our reason, therefore, demand that if any system pretend that God has personally connected himself with the history of man for such purposes, it must show that he has fulfilled these conditions, under which alone we are able to conceive the possibility of such a fact. And thus we find in the very nature and conclusions of reason itself, a profound basis for belief in the incarnation. Such, then, is a rapid review of the discussion, through which we have arrived at the point, when we must analyze the life and character of Christ, to see whether he claimed to solve the great problem of humanity, or proffered merely a mediate revelation of the will of the unknown Deity. And, since we have thus from the very conception of God, reached the solution of the 
problem, how alone a revelation of God himself into the moral history of man is possible, there is no place more suitable in our discussion than the present, for approaching the highest and deepest problem of all, namely, in what manner reason can conceive of the personal and self-conscious existence of an infinite and unoriginated spirit.

The only conceptions which we can form of Spirit, are necessarily derived from the observation of the subjective phenomena of our own consciousness. The fact there lying beneath the very possibility of all observation, and constituting the central unity as it were, of our whole being, is undoubtedly the recognition of self, of personality, which is implied and involved in every act of consciousness. But this very self, this identical person, the same amidst every fluctuation of subjective emotions. and objective changes, the one, consciously responsible Being, regulating himself by an internal power according to the dictates of reason and conscience, or violently contravening those dictates, is Will, Personal Will, conscious of its own exercise. So deep, so abiding, so spontaneous, so rooted in man's inmost essence is this conscious identity of self and will, that nothing but the annihilation of the soul could destroy it. It is the man himself. And we appeal to the most accurate analysis of consciousness for the fact. It is that which essentially distinguishes a person from a thing, and elevates man above the low sphere of being a mere mechanical link in the physical chain of 
cause and effect. This is the true source of our conception of power and consequently of causation. It is not necessary to prove this here by analysis, since it is enough for our present purpose to obtain the fact from our consciousness, that personal will is essentially involved in our conception of spirit, and we need not probe deeply the mysteries of our being, to obtain the other two elements which complete that conception and contain all else which we predicate of spirit as its peculiar and essential characteristics-namely, intelligence and emotion. The former, as a general term, including all that belongs to reason and understanding ; the latter, all that belongs to feeling, passion, affection.

But how do the recognition and the action of these three essential attributes of spirit become possible for man? By that deep and fundamental distinction of subject and object, which Grod has constituted as necessary and essential in the very nature of things. Shut up within the circle of his own subjectivity, man could never even know himself. But it is by his recognition of something which is not himself, that his clear personal consciousness arises; it is by his perception of a universe that his understanding recognizes and puts forth its powers-for without objects of knowledge, there can be no exercise of intelligence; and it is by finding out of him. self, a reflection as it were of himself, that his affections come forth into possible development towards appropriate objects. The subject and object necessarily suppose and 
imply each other, and even when they become identical, as when the mind turned inward upon its own processes is the object of its own reflection, there is still the clear perception and consciousness of the distinction.

Reason can not avoid applying these necessary conceptions to her idea of all spirit, they are the only conditions under which she can possibly conceive of intelligent, self-conscious existence. When, then, she asks herself how she can conceive of an infinite, unoriginated Being, before and independent of all other existences, she is compelled to affirm that she must conceive it only under two conditions; either as mere Being, the necessary impersonal substratum of all existence, subject itself to some unavoidable law of evolution, whereby alone can arise other existences, from the necessary development of a physical energy of the absolute Being; or, she must conceive that infinite and $\grave{a}$ priori Being as a personal spirit. But for the possibility of this conception, she must further ask how, to her finite condition, the conception of the personality of such a spirit can be possible.

We can have no experience from without of what personality consists in. It is only by realizing it in our own consciousness that we can conceive it, and we have no means of conceiving it in other beings, but by employing the conception drawn from our own consciousness. Now personality is, in us, clearly distinguished from mere consciousness. It is that which alone gives unity to our consciousness, and as the recognition of self, it is the con- 
sciousness, determined or limited, as that of the personal subject self-distinguished from object. The very consciousness of personality involves the necessary limitation of the existing and conscious subject as distinguished from mere unlimited Being.

In a finite being, personality and individuality are so intimately connected, that the conception of an intelligent reasonable individual, implies and involves personality. But individuality can not be predicated of infinite Being, because individuality itself arises from external limitation, contrast, and relationship towards other finite objects ; and infinite Being, from the very force of terms, can admit no such limitation; while the mere conception of Being, the infinite ground of all existence, does not itself involve personality. But the very ground and essence of this mysterious prerogative is the conscious recognition of the $I$, the conception of which necessarily involves the limitation of the personal Being, as the antithesis of the boundless, unlimited ALL. As there can not possibly be any external object to the Infinite, existing alone, that limitation which makes the self-conscious $I$ possible, must exist in the depths of its own essence. The subject in recognizing or pronouncing itself as $I$, necessarily makes limitation of its personal being, and by unavoidable implication asserts a correlate objectivity. This must lie in the necessary and everlasting conditions of the infinite existence itself, or the Eternal I would not be possible; and we would then, if we regarded not the 
universe itself as the absolute Being, be left but the two alternatives of, either conceiving the absolute Being as mere passive oneness undeveloped subjectively-an unconscious monadity, producing creation objectively under a mere law of Being, and never reaching self-consciousness; or, of conceiving the absolute Being equally developing itself objectively under a necessary law, and only attaining a quasi self-consciousnesss in the evolution of finite intelligences. But in infinite spiritual essence, one by the very necessity of its nature, the correlate object of the Eternal $I$ must be also person, absolute and eternal reflex of the Subject, essentially rooted in the one, uncompounded nature. The infinite personal Being can only be truly conceived as subject-object, in the synthesis of eternal unity of essence. The same conception of the necessity of correlative objectivity arises, when we attempt to realize the conception of infinite Being clothed with active moral attributes, finding their real, eternal, and perfect operation and satisfaction.

When then reason rises to the conception of the absolute and unoriginated, if she would not conceive of it as mere necessary cause or power,-if she would not fix it in the immobility of mere boundless subjective existence with no possible development,-if she would clothe it with the attributes of self-conscious personality, and active intelligence, and living affection, she must, by the necessity of her own laws of conception, find in its own infinite unity the objectivity which can alone give possi- 
bility to the idea of personal, intelligent, emotional existence. The finite spirit finds in a round-lying objective world, the necessary conditions for the operation of its own self-consciousness, intelligence, and affection; but the infinite ground and cause of all existence, can not be comprehended by reason as recognizing its self, its own distinctive personality, the operation of its own intelligence and of its active affections, unless its necessary objectivity be found within itself. But since a spiritual object must necessarily involve Consciousness and Will, as that which essentially distinguishes spirit from matter, person from thing, and since there can be only One Infinite Being, in whose own essence consequently must be found subject, object, and the synthesis of the two, reason must affirm a principle of plurality in the divine essence itself, as a necessary condition of the possibility of her conceiving the existence of an Infinite, Self-conscious Being. It is useless to say that we must not apply to the Divine Being conceptions drawn from the necessities of our own existence. We can possess no conception of personal, spiritual existence, except what we derive from the depths of our own Consciousness; and the true logical result of neglecting these laws of our consciousness and conceptions when we reason upon Absolute Existence, is seen in the results arrived at by those profound thinkers, who, following out strictly the necessary conclusions of such a mode of reasoning, have, on the one hand, sunk all existence into an impersonal pantheism of 
nature, and, on the other, have absorbed all existence and all nature into mere Being without Self-consciousness or Will. If we deny plurality in the Divine Essence, we must logically either land in the material pantheism of Comte, or the immaterial pantheism of Hegel; or, if we refuse these results, and cling both to the denial of that plurality and also to a personal God unconfounded with the intellectual or material universe, and eternally personal, we can only do so by the illogical, though certainly happy, abandonment of those philosophical conceptions which make the idea valid to reason. For to say that personality, that is, the I, or Self-consciousness, does not imply limitation of Being, and by necessary implication Objectivity; or to affirm that any Being can be Selfconscious without the necessary condition of Objectivity, and hence that infinite Being can be without that condition being embraced within his own essence, and hence involving plurality, is to assume the whole question, and to ignore reason altogether upon points where the appeal must be to reason itself. Where personal plurality in the Divine Unity has not been held, earnest and logical thinkers have been carried on irresistibly to pantheism or atheism, as among the soufis of the Mohammedans, and among certain philosophical schools in Germany. And it is very significant of this fact, that Schelling, one of the greatest geniuses of the German Pantheistic School, in his latest works, where he endeavors to rise above the pantheism of his earlier system, by arriving, through 
reason alone, to a Personal Deity, has felt himself compelled to realize the conception by a certain philosophical trinity in the Divine Essence itself. Our argument, then, may be so far useful as to show that the plurality in the Divine Essence, is not a mere question of scholastic paradoxes, but is bound up with ontological conceptions, which necessarily arise when we attempt to realize philosophically and definitely the idea of Personal Infinite Being. 


\section{H A P T E R I V.}

ANALYSIS OF LIFE AND CHARACTER OF CHRIST.

Believing that there is a God, to whom conscience tells us we must be accountable, and overwhelmed by the perplexity and awful mystery which press upon us from every side, and envelope our own being and its destiny; we look naturally to the prevailing religion to see what answer it can give to the deepest and most solemn queries of the soul. We find that christianity claims to give the desired light, so far as it is necessary in the present existence for man to know. We enquire into the history of this christianity, and find it clear that Christ did live and proclaim a religion, and that his disciples were persons of honesty, integrity and truth. We find that they wrote an account of Christ, his claims and teachings; of the genuineness of which book we are satisfied, upon grounds precisely similar to those, (although far stronger,) upon which we receive the history of Thucydides. In fact, if one will take the trouble to investigate the grounds upon which the credibility of the Gospels rests, he will perceive that there is no logical stand-point for the philosophic mind, between admitting 
them as substantial history, and absolutely denying the existence of Christ at all. If the existing evidence for the historical truth of the Gospels be insufficient, it is absolutely impossible to receive as valid any human testimony which can be produced for any fact which transpired a century ago. Taking then, as a valid standing-point, that the Gospels are history, it is perfectly plain that in order to see what Christ taught and who he was, our only course is to begin by reading the New Testament.

Now, there are two modes of arriving at the meaning of this book, both based upon common sense, and both of which we must combine in the investigation. One is synthetical, and the other analytic. We shall first state the principle upon which the former rests. All philosophy and all history teach us that there is an universal voice of humanity, a common consent of human reason and human convictions, which is always based in truth, anc which we universally accept and act upon as a legitimate authority, unless we place ourselves in the categories of absurdity or insanity. We may be able to prove that peculiar and partial facts based upon these convictions, are erroneous; we can not reject the general principle affirmed by the universal voice of humanity, without imperilling our title to common sense or sound judgment. Of the nature of such partial or erroneous facts, might be a peculiar plan for the construction of a life-boat; we might reject it as faulty; we could not reject the principle 
of self-preservation without insanity. We might deny the correctness of a system of mythology; we could not deny the religious element in man, or the belief in Deity, with out a folly which would contravene the inmost instincts of human nature. In like manner true philosophical analysis and plain historical induction, teach us that there is an universal voice of christianity, a common consent of christianized humanity, which is also always based in essential elements and doctrines of the christian religion. In view of this, we might reject a particular interpretation; we could not reject the New Testament, which all christians have ever received, unless we reject the validity of any christianity at all. The universal consent therefore of christians always and every where to any religious principle or doctrine, is the most powerful testimony to its being a necessary part of christianity, although different partial views may have been based upon it. And if, in proportion to the increased knowledge, learning, development and investigation of the christian world, such religious principle or doctrine is still undoubtedly held as a necessary part of christianity, even amidst the most opposing views, and explanations, and theories, built upon it, it acquires the very highest validity as true, if christianity itself be true at all. By putting together, then, these common consents of christianity, we obtain a real authority and guide for individual judgment, as an objective source of arriving at the meaning of the christian records. This is what is meant by the synthetical mode. 
By the analytic mode we, of course, intend the examination of the records themselves. It is a foolish objection against examining them, that the most learned scholars have differed in their interpretation. We may account for their difference or agreement, just in proportion as they have paid regard to the synthetical or objective mode. But the most learned scholars have differed in their interpretation of Plato and other Greek writers. Are we, therefore, not to read Plato, or before reading him, must we adopt a partial interpretation, and make him accord with it? And, remember, in such interpretations we have no such universal guide to aid us, as we have in the common voice of christianity. Nevertheless, the dictate of common sense is, to interpret Plato according to the laws of Philology, in order to see what meaning his sayings appear naturally and justly to bear. It is obvious that we must first know the contents of a book before we can apply any external system to its interpretation. And although in interpreting the New Testament we ought to employ the synthetic and analytic modes combined, yet, if we suppose an individual, as yet, ignorant of the former, but merely in possession of the New Testament itself, its analytic perusal will, itself, set him upon the search for the common voice of christianity, if he indeed feels an earnest longing after the truth of the book.

Upon opening this book, the very first line is, "Book of the generation of Jesus Christ, a descendant of David, 
a descendant of Abraham."* Here is one fact, then, we learn about Christ; namely, that his disciples believed him to have been born from a certain line of descent among the Jews. The genealogical list is then given, until it comes to a Joseph, who is called the husband of Mary, from which Mary, Jesus was born. We remark here a change in the mode of giving the genealogy. All the preceding names are of men, (with no mention of their wives,) who are said to have begotten other men; and so on to a Jacob, who begat this Joseph. But it does not say next, that Joseph begat Jesus, nor even that he begat Jesus from or with Mary, as is the usual mode of giving genealogies. But it is said that Joseph was the husband of Mary, from whom Jesus was born.

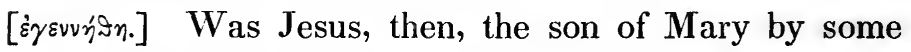
other husband, than Joseph; or, is this a mere singularity on the part of the writer? In reading on, we find neither to be the case; but the writer expressly says, that Jesus was immediately created by God, without the intervention of any secondary cause. So extra-

* The two first chapters of St. Matthew's Gospel are found in all the MSS. and ancient versions. The grounds alleged against their authenticity, are entirely internal ; and without here examining them, it is enough for the purpose in view, to state, that they indubitably embody the general facts believed, respecting the birth of Christ, by his immediate followers ; facts which must originally have come from his own family, and whose intrinsic truth can not be affected by any difficulties in harmonizing the narrative with St. Luke's or itself. 
ordinary a miracle, at once suggests, that a child thus unusually created, must be intended by God to be a very remarkable and important personage. In the last chapter, the true ground of the probability of miracles was shown; and if God meant to reveal any thing about Himself in christianity, it is reasonable to expect that He will have done so in some extraordinary manner. And it is certainly not more wonderful, or difficult to believe, that as God created a first man, so he should also create a first revealer. Besides, since, as it has been shown in our first chapter, reason would naturally lead us to expect a revelation, the claims of christianity as such, must rest upon appropriate evidence.

The extraordinary character of this child, is also told in a divine dream to Joseph. The Deity, by this dream, informs Joseph that Jesus shall save his people from their sins, and that he is God-with-us; a very suitable name for the revealer of God's will. Now, the beliefs of individuals, and even of nations, may be utterly false and ungrounded; but human nature, in its universality and unity as nature, believes nothing, in every diversity of the development of humanity, which has not its basis in the real and true. But such a belief of human nature, is the belief in the possibility of subjective communications from Deity, through dreams, inspiration, and similar channels. Thus far, then, there is nothing in the history of Jesus, which contradicts the instincts and common notions of mankind. Next, it is said, that eastern Magi 


\section{ANALYSIS OF LIFE AND CHARACTER OF CHRIST.}

came and offered homage to the child Jesus; whence it would seem probable that there was expectation and tradition, (as we know historically to have been the fact,) of some extraordinary being appearing in the world; and Herod and Jerusalem seem to have believed it also, and to have been expecting a Christ, or Anointed One. However, Herod feared, as it appears, that Christ would come into possession of the government, and therefore murdered the children where Christ was expected to be born; from which destruction Jesus escaped, by his mother and Joseph being admonished by a divine dream, to flee with the child to Egypt. The writer of this first gospel, now before us, quotes sundry prophecies which he applies to Jesus. Now, whether the application be correct or not, it can not affect the fidelity of the writer as a historian, in which light, at present, we are regarding him ; and it proves, moreover, that from certain old prophecies, there was an expectation of some such extraordinary being. Next, we have the testimony of John, himself a remarkable teacher, to Jesus, as to an extraordinary personage; and when John baptized Jesus, there was a sign from heaven; every thing, as we progress in the history, showing clearer and clearer, that Jesus was some uncommon being, having a great mission to perform. Next, in the account of the temptation, however this transaction may be interpreted, it is indubitably manifested by the historian, that Jesus claimed to be, and was regarded by his disciples, as the Son of God. 
And this title is certainly most appropriate, even in its lowest signification, as applied to a person who was created directly in the womb, without the intervention of any human progenitor. Jesus, now is said to have commenced his mission, by proclaiming repentance and the approach of the kingdom of heaven, and by collecting disciples, and healing diseases. He attracted crowds of hearers; and we have next a discourse which he delivered to them; and in which, we naturally look for some of his doctrines, and some exposition of his mission. There is an evident claim throughout, of the highest authority to teach, and of the imperative duty of subınission to his precepts. It is, indeed, the most remarkable didactic piece on record. It is in a noble style of calm, dignified, and majestic authority ; in which reason, persuasion, and command, are admirably blended ; the loftiest tone of morals pervades it; the prayer dictated in it can be pronounced nothing less than divine $;^{*}$ and its peroration is a most impressive example of unimpassioned and solemn grandeur. It inculcates the noblest justice ; the most unostentatious humility; the highest piety towards God and man. It declares the worthlessness of empty formality; the value of simple, private prayer; and presents a pattern and embodiment of that purest virtue, towards which the good man ever yearns, and a rule for which the sincere philosopher ever desires. It

* What wisdom was necessary for its compilation. 


\section{ANALYSIS OF LIFE AND CHARACTER OF CHRIST.}

inculcates the deepest and most fearless trust in the goodness and care of God; while it shadows forth the divine justice, by its earnest warning, that eternal life is only to be entered by serious effort.

From all, then, which thus far has attended the birth, life, and words of this extraordinary, (and, as he may justly, in view of his birth, be termed, supernatural,) being, we are led to look for an unexampled career of miracle, wisdom, and holiness, manifesting, as has never yet been done, the will and character of God. We shall not thus continue the analysis of every page of the Gospels, but assuming that we have acquired their contents, we must endeavor to seize upon what will at once be evident as the most prominent and important points in the narrative, and apply our method of analysis to these. They obviously arrange themselves under two general heads; namely, the fundamental characteristics of the miracles, and of the sayings of Christ.

In attentively examining the miracles of Christ, we are arrested by a peculiarity, which separates them by a broad distinction from all other alleged miracles. They are not merely works of benevolence or power, but they possess a deep moral and spiritual significancy ; and they are wrought, as by a will immediately controlling and pervading all nature, through its independent and personal authority. To develope this fully, would of course demand (what we here can not turn aside to pursue) an extended examination of all the miracles recorded in 
the Gospels, and their comparison with other facts of the same nature related in scripture. In illustration, however, of the striking characteristics of Christ's miracles which have been mentioned, we must confine ourselves to a brief example. And, to render this as striking as possible, we shall select* the two miracles, which to the superficial eye, would appear least of all to present the high characteristics which are involved in these works of Jesus. For, if in these we can clearly detect the striking peculiarities before referred to, we shall be little doubtful about finding them in the more solemn and grand exhibitions of miraculous power by the Son of God. The first, then, to which we allude, is the cursing of the barren fig-tree.

Christ had just made his extraordinary entry into Jerusalem, and rebuked the Scribes and Pharisees for their pretension to authority and knowledge of the truth, while in fact they did not the holy and pious works of that law which they pretended to expound. And he had also rebuked the whole Jewish nation for its claims to light and privileges which none others enjoyed, while they brought not forth the fruits becoming such lofty claims. To print these truths deeply in his disciples hearts, to show them in the most striking and convincing manner that high pretensions and claims to superior authority

* See Trench's "Notes on the Miracles" on the two miracles selected above. 
and privileges, were not only valueless without an exhibition of the life, virtues and holiness which such claims implied, but that they tended to absorb in mere pride and display and profession, the energies of the heart, which should be rather occupied with earnestly producing the vital fruit which such privileges demanded, Christ gives one of his impressive lessons, calculated to sink into the deepest convictions of his disciples, and to assure them of his awful power, as a ground of trust in him, and of the earnest necessity of living according to the privileges which they received. In view of his solemn teachings and his reality of life, as contrasted with the hollow want of earnestness in the Jewish teachers and nation generally, the fig-tree stood forth, as a striking symbol of these latter. The Jews boasted of their exclusive privileges; God then, justly could look, for corresponding fruit. The fig-tree put forth its boasting leaves; the passer then, justly could look for ripening figs. Moreover, notwithstanding their boasted possession of the prophecies and consequent expectation of the Messiah, the Jews waited not faithfully for the fulfilment of Grod's promises in his own good time, but running, as it were, before they were sent,-neglecting the indications of Divine Providence,- - they proudly pretended to a light and a righteousness which was, in their estimation, perfect, and thus they could not even recognize the Messiah as a teacher, but setting up themselves as the model and instructor of all nations, they only wanted a Messiah 
who would enable them to impose their dominion and law upon all the world. Thus the fig-tree, as a symbolic type, displayed in a concrete form (and so brought home to the oriental understanding and conceptions of the disciples,) these characteristics of the Jewish nation; for as the fruit always appears upon that species of tree before the foliage, the existence of foliage, of course, is a virtual declaration of the progressing maturity of the fruit; while, as the "time of figs was not yet," this remarkable precocity over the other fig-trees would strengthen the ground of expectation for fruit. Like a proud boaster, the tree, before the due time of providence, invited a comparison of its value with the tardiness of its fellows. If it had indeed enjoyed greater privileges than the others, of dew, and sunshine, and soil, so much the more disgraceful was its expenditure of all its energies in empty foliage-an expenditure which itself had frustrated its ever producing fruit. And Christ seeing into the deep causes which rendered the tree fruitless and boastful, and which, perhaps, were also preparing its speedy decay, hastened on the operation of these causes, without reference to other authority than his own word, as though all nature depended upon his sustaining power. With this view as a key to our mode of regarding the miracle, each one can readily for himself perceive its high significancy as an embodiment and display of profound truths. It is no exhibition of paltry spleen and disappointment; no merely wonderful way of suggesting some obvious 


\section{ANALYSIS OF LIFE AND CHARACTER OF CHRIST.}

moral maxim, which might have been uttered just as well in the form of an ordinary precept; but it is a solemn symbol of a nation's spiritual character, of the secret causes which were undermining its stability, and of the result of their operation. It is a wonderful concentration of Jewish history, and it gives us amazing thoughts of the Being whose Spiritual Perception was so appallingly deep and piercing, and whose claims over nature were so direct and resistless.

The other miracle, to which allusion was intended, is the directing Peter to find the tribute money, by taking the first fish he should draw from the lake, and searching for the coin in its mouth. Some have thought that this miracle is unworthy of the lofty character of Christ, that it is undignified, and that it is a superfluous introduction of supernatural machinery. When viewed in connection with the history, and all that we have observed in the Gospels of its wonderful author, it appears in a very different aspect to the earnest and deeply observing enquirer. The impression that he was more than mortal had been growing in the convictions of his disciples, and Peter had been pronounced blessed by him for the confession that he was "the son of the living God." The account, immediately afterwards, of the strange and sublime vision of the Transfiguration, clearly proves that his disciples had been led to regard him as the son of God, in some preeminent sense, and however we may choose to explain particular events or phrases in the pages of 
the Gospels, it is mere trifling to allow these Gospels any real objective historical validity at all, and not to perceive and admit, that they convey the impression that Christ had himself designedly and strenuously led on his disciples to regard him as mysteriously connected with Deity. Now when Peter was asked whether his master paid tribute, he undertook to affirm it on his own authority; thus manifesting, (among other things which here we have not time to examine,) a wavering as to the supreme authority of his master. 'This tribute was not to the Roman Government; it was a tribute to the Temple, falling under the Jewish law alone, and hence, as the Jews had not the civil authority in their hands, whereby to enforce it, it become entirely a voluntary payment. On this very account, therefore, Peter should first have enquired of his master whether, as the Messiah, he would pay this contribution. Christ anticipates any communication from Peter on the subject, and the direct inference which, in connection with all that he had heard and seen, Peter must have drawn from Christ's question, (the question itself showing that Christ knew what Peter had said) was, that as the children of earthly kings are free from tribute, so Christ was free from this tribute to the King of the Temple, because he was the son of that King. And then, to confirm this inference, to establish Peter in his own previous confession, and to deepen the conviction that the will of Christ pervaded and ruled the whole realm of nature, instead of paying the tribute coin from 
the common purse, he sends Peter to obtain the coin in a manner which, under all these circumstances, must have awakened new faith in the disciples, and filled them with awe at the vastness and mightiness of their master's claims. From this point of view, the miracle, so far from seeming undignified or unworthy, is at once invested with great grandeur and deep significancy.

In passing now to the sayings of Christ, we are already prepared to expect, upon their analysis, profound and mighty doctrines. His solemn declarations, that he is the Son of God, and the Son of Man; that no man knoweth the Son but the Father, and no man knoweth the Father but the Son, and he to whomsoever the Son will reveal him; that the Son is in the bosom of the Father, and yet that there is an hour whereof knoweth no man, not even the Son; that Christ partook of the glory of Deity before the world was, and that he yet spake às God who had sent him, gave him commandment; that the especial title of absolute divinity, as understood in the language of his hearers, the Jews, belonged to himself e'er Abraham existed, and yet his solemn prayers to the Deity, as his friend, protector, and father; the clear impression which he conveyed, even to his unphilosophical hearers, that he made himself equal with God; that all men should honor the Son even as they honor the Father, and yet that the Father had given all power to the Son; that he was sent to do the will of God, and yet that the Father was manifested 
in him; all these, with numerous other and equally astonishing and unparalleled declarations, throw us upon one of two suppositions : either, that the greater declarations, contrary to all logic and reason, are to be emptied of their significancy, and reduced to mere verbal trifling for the sake of the lesser declarations,-a result which can only be obtained at the serious cost of adopting a mode of shallow interpretation, which can stand the test of no searching criticism, while it would be difficult to prove why the lesser declarations should not, with equal propriety, be made to succumb to the greater; or, that both classes of declarations are equally valid, if any weight is to be attached to the laws of philology, and the character of the extraordinary speaker. In short, we have the whole gist and matter of these declarations, clearly and explicitly gathered up in a focus, and set forth, without ambiguity, in the two declarations of Christ, "My Father is greater than I," and " $I$ and the Father are one." Now, in every department of knowledge and science, where the harmony of established law is apparently violated by palpable contradiction, the elements of the seeming disharmony will be found to resolve themselves into the operation of a higher and more comprehensive law, whereby unity and concord will again be obtained. This principle is so perfectly established, so commonly acted upon, that the appearance of contradiction, at once sets us upon further investigation and more critical analysis, in order to discover 
the higher law, which includes both of the opposing facts, and reconciles the incongruity. In the case before us, reason at once finds, in the conclusions we deduced in our second chapter, from her own principles, respecting the possibility of God revealing himself, a logical ground for the resolution of the difficulty, and the comprehension of the claims of Christ. He was God manifest in the flesh; and incarnation no longer remains a mere subjective theory of the science of reason, but becomes a claimed, objective truth in the person of Christ. Here is the crowning point, the culminating harmony of this wondrous being. Here is the deep unity which pervades the entire narrative, and runs like a key note throughout its varying strains. And here is the verification of the hopes and prophecies of humanity; the answer to its yearning instincts and demands. God has manifested Himself in His moral world; He has provided the great Synthesis of Human and Divine; He has linked Human Nature to the Divinity; and made a living way for Man to God.

As we pursue each recorded step of the life of Christ, his greatness, his wisdom, his awful goodness, his supernatural power, his innate authority, the whole of his wonderful and unexampled character, overwhelm us with wonder, admiration, reverence, and affection; and impress us with the conviction that divinity lives within him, and that he is more than mortal. There is an unearthly majesty and grandeur about him, which is more 
striking and astonishing from the very poverty and simplicity of his life; and it seems almost impossible that an earnest thinker, who longs for light from God, should not perceive, upon a first acquaintance with the history of Christ, that he is every way worthy of being the revealer of God, and that he actually must have been sent by the Deity for that momentous purpose. The amazing and evenly sustained congruity of the character in all its parts throughout, without effort, but by its own innate completeness, loftiness, and homogeneousness, irresistibly compel us to believe that Christ was all that his disciples believed him to be. If we actually appreciate the awful mysteries which envelope our being, and sincerely long for truth and light, nothing can prevent us from hailing Christ as the guide and teacher whom we need. And when, in addition to all this, we reflect upon his own solemn declarations, respecting the deep significancy of his death; when we see him rising in triumphant glory from the tomb, and ascending in majestic power, until lost in the dazzling splendors of Jehovah's throne; when we appeal to the Universal Voice of Christianity, and view the whole life of Jesus in the light of the religious history of mankind, ever dimly pointing to sacrifice and redemption; we feel an ever accumulating weight of conviction, that Christ came to place humanity forever in a new relation to God, to answer the doubts which have ever pressed upon thinking men in all ages, and to point out to all men the certain way of eternal 


\section{ANALYSIS OF LIFE AND CHARACTER OF CHRIST.}

salvation; that he has shown the way by which we are saved from the fatal consequences of $\sin$; that his death, or shedding of blood, is connected in the purposes of Deity with the pardon of $\sin$; that this is the great object of our belief, and the solution of the fundamental problem of humanity, how man is reconciled with God; that believing in this central mystery, holiness must be our aim; and that Christ, before incarnation, was eternally connected in his essential being with Godhead. These results, obtained directly (without applying any antecedent theory, but) from a logical analysis of the New Testament, as a mere credible history-an analysis neither explaining away, nor seeking to find more than, what is contained in the narrative itself,-are confirmed by the general consent of christianized humanity, which testifies (however it may have differed in particular communities, as to special theories erected upon the fundamental idea,) that it has ever been an essential part of christianity to believe that Christ was God and man, eternally and essentially connected with Deity, and also possessing a perfect human nature; that he was an example, a revealer of God's will, and that he also gave his life a ransom for the world; that he was the holiest moral teacher, and that also the pardon of sin and salvation, are connected, in the providence of God, with the death of Christ. And reason perceives at once, how, in incarnation, all these oppositions meet and harmonize perfectly; and thus leave a full historical value to the New Testa- 
ment, without any fact being at all modified in its full signification, for the sake of any other fact. If we take away, either the divine or the human element from the character of Christ, we destroy its harmony, and render difficult the explanation of its various phases. If he was merely an inspired being, then there would have been no essential, absolutely real, contact between human nature and Deity; and the world must still, then, hope that perhaps God will yet himself enter into its moral history, and place humanity forever in a new and redeemed relation towards its Creator. A mere prophet or delegate could only have indirectly introduced into the world moral principles and motives, calculated to elevate the moral nature of man, and to further the general improvement of humanity. But no precepts, or examples, or incitements, or moral truths, could affect the constituted and existing nature of man, in its essential relations to Deity. This would evidently require that nature to be itself affected in its universal essence, to be taken hold of by Deity, who is not subject to its conditions, and who can enter into them, for the purpose of introducing a modifying element into humanity itself, by bringing its nature immediately in contact with himself. The fundamental unity of human nature, would render this actual contact valid for all time; would forever place humanity in a redeemed relation to God; and if Christ was this point of contact, this real synthesis between divine and human, his astonishing and paradoxical sayings become intelli- 
gible; his whole character is sublimely consistent; his teachings, his claims, the views of himself held by his Apostles, and with difficulty conceived to have originated except from his own words, all become justifiable, reasonable, and proper.

The instinctive jealousy with which the overwhelming mass of the church has ever clung to the conviction that Christ was God and man, proves that it rests upon some deep necessity of the heart, some vital hope of humanity, which neither the logic of the sceptic, nor the scholastic paradoxes of the divine can demolish or render absurd. While the logician, on one hand, finds himself involved in inextricable subtleties as to how God did unite himself with humanity,(so as to preserve the two natures of God and man, without separating them into a mere alliance of two persons, or confounding them in a tertium quid, or how a perfect humanity, with a will can exist, and yet be without any personality, except one personality common to two natures, which yet as natures are each perfect, although personality is an essential attribute of both natures:) The Philosophic Theologian, on the other hand, in the simple fact of God having truly united himself with human nature, (without presuming to define the modus occultus et incompertus, which in none of the works of God can the finite intellect penetrate, $\left.{ }^{*}\right)$ finds one of the deep-

* There is always a point beneath the laws of God, to which we can not penetrate. We may reach the conclusion, that if God introduce himself, his own personality, into the moral history of 
est wants of man supplied, in his being furnished with a Personal Redeemer, who brings within the sphere of his affections and sympathies the attributes of that infinite Jehovah, who otherwise would be to man a distant, diverse Being, severed by the vastness of his unconditioned existence from all to which humanity can attach itself; while in Christ, he has entered into the bosom of humanity; he has given us an intelligible impersonation of his justice, his mercy, and his love; and has revealed to us a Divine friend around whom all the deepest and noblest yearnings of our nature can cluster without superstition, and whom we can lovingly adore without the possibility of idolatry.

humanity, so as really and literally to take human nature into contact with himself, and so place it in a new relation towards Divinity, duty and salvation, he must necessarily do so by incarnation; but beyond this we can not reach, and fathom the secret mode in which he unites his personality with man, any more than we can explain, or divine how it is, that the sun beams, impinging upon the optic nerve produce the phenomena of sight. And yet thus much we must say, that our view aroids the revolting error of Theopassianism, by holding that in Incarnation, (or the Personalization of God in Christ,) Deity immediately connected Himself with Human Nature by in-Fonming Christ with the Divine $\lambda$ óros. 


\section{H A P T E R V.}

\section{ADAPTEDNESS OF CHRISTIANITY TO THE RELIGIOUS WANTS OF MAN.}

WE have now, perhaps, reached the proper period in our discussion, for casting a rapid glance at the wants which were actually manifested in reference to religion, before the manifestation of Christ, and at the manner in which christianity responds to them.

Surrounded as we are from the cradle by that condition of things, and all those influences which the prevalence of christianity for centuries has produced, it is almost impossible for us to realize what would be our intellectual, moral and social condition, if christianity had not yet dawned upon the world. Nevertheless, we may apprehend what would be man's condition in its most favorable phase without christianity, by referring to the state of the most civilized and intellectual portion of the ancient world, before the manifestation of Christ. His words, recorded in St. John's Gospel, that he was come a light into the world, seem to us to imply that until his coming, the world was, and would have continued to be in a state of darkness or doubt; but that he has brought 
light into the world, unto every one who is willing to believe. In other words, that christianity is perfectly adequate to meet and satisfy all the intellectual, moral and social wants which man can feel in reference to religion. We shall not, then, indulge in any hypothesis as to what man might require of a professed revelation, upon whose claims he was called to sit in judgment; but we shall adduce what we know to have been his actual wants, felt and recognized, before he knew that there was any prospect of their ever being relieved. The general religious, moral and social wants of a common nature must be every where the same; and we can learn those wants from the ancients who experienced and recorded them, before the son of God came a light into the world.

Among the Grecians, where the intellectual powers appear to have attained the highest degree of development, we may learn, perhaps, the subtlest wants of the human mind, which left unsatisfied, would invalidate the claims of any religion declaring itself divine. One of the most primary of these wants must be observed to be, the necessity of an authoritative, objective, declaration of truth. For when the mind had already obtained glimpses of the truth, of what it felt ought to be the truth, but which it could not demonstrate; or when it had arrived by a process of logical induction to what it perceived to be abstract truth, but whose concrete existence, while it felt it to be necessary for the well-being of the universe, it yet could not prove to possess an objective existence; 
it was then that it needed some authoritative voice to confirm its conclusions, to assure it of the certainty of its expectations, and to warrant it to believe as actually valid, what it subjectively felt ought to exist. In the mind, which by the effort of reason alone, is endeavoring to solve the momentous problems of its duty and its destiny, of the universe and God, this want of Divine aid and revelation is clearly manifested as existing strongly, by such expressions of Plato* in his books on laws, as these :- "If ever," says he in the 10th book, "we ought to call upon God, let it be done now ;" and also, in the 4th book, he says, "let us invoke the aid of God." "May he hear us, and when he has listened to our requests, may he kindly and propitiously come to our assistance."Again in his Timæeus he says, "Even these who have but little of sobriety, in the undertaking of any affair, whether of small or great consequence, always call upon God. Much more then, when about to engage in a discussion respecting the universe, whether it is generated or eternal, ought we to invoke God by prayer, that what we say may be, first of all, according to his mind, and then consistent with ourselves." In the Laws again, he speaks of holding fast to the hope of Divine aid. And especially in that well known and memorable declaration in the second Alcibiades, he says-"That we must wait

* The translations of the classical passages in this chapter are taken from Prof. Lewis's "Plato Contra Atheos." 
patiently until some one, either a God or some inspired man, teach us our moral and religious duties, and as Pallas, in Homer, did to Diomed, remove the darkness from our eyes." And in want of this longed for light from heaven, we find Socrates represented in the Phædon, as clinging to the authoritative voice of universal humanity; "unless," says he, "perhaps the soul may hereafter find a surer vehicle in some Divine revelation, which heaven might yet condescend to make known to men." Christianity responds to this primary want of the soul by declaring that it possesses and will afford the light for which the earnest spirit sighs. And that it does afford this light, is in nothing more strikingly evident than in the fact that we who enjoy it, can scarcely conceive of the darkness and difficulty which existed, for even the greatest intellects of the Grecian world, upon points which, even if individual understandings reject christianity, are clearly perceptible by reason, since the introduction of christianity, to be agreeable to her highest conceptions.

The Greek philosophers perceived, that by the very constitution and laws of our mind, we are compelled to assent to certain things as necessary truths; some of which are at once evident, as that two straight lines intersecting each other at right angles, can never coincide, if prolonged to infinity; and some of which, although equally necessary, require a greater exercise of intellect to apprehend them, as that the sum of the angles 
of a triangle are equal to two right angles; and some again are so recondite, that although the necessary laws of reason lead to their conception, yet they are not evident as necessary truths, without an analysis of the ope- rations of the mind in arriving at them, and of the laws of reason themselves. Such are the conceptions of Space and Time and Causation; and such to the ancient sage, was the existence of one Infinite, Eternal, Personal God. It was his most profound and difficult problem. He felt that his reason, by its own necessary laws, compelled him to account for the existence of the universe, for a First Cause, and for his own existence and destiny. But he could not see clearly the full conclusions to which reason pointed, and which she implicitly contained in her own depths. If he could, after laborious investigation of the operations of his mind, see that there must be an Eternal and a Divine, the perfect realization of the absolute Good and Beautiful and True,-which he felt, for the perfection and just government of the universe, and for his own hope in eternity, must be personal, and clothed with the attributes of God; if he even progressed so far as to see that these conclusions might possibly be of a similarly necessary nature with geometrical truths, he was still destitute of the only authoritative confirmation which they could possess-the voice of an objective revelation. Dark, indeed, must be the condition of the earnest, the sincere, the virtuous soul, which can clearly perceive that for its own eternal hope, it is a necessary 
thing that God should exist-a Creator, a Present Ruler, and a Future Just and Rectifying Judge, and which yet has no word from him to manifest his being, or to utter a guiding law. And had we not christianity, we would still be involved in the subtle perplexities which occupied the Grecian sages ; for the essential laws of our reason would compel us to seek a solution of the same problems, respecting the universe, the Deity, our souls, our destiny; and seeing with Plato, that there must be a God who is supreme, and a judgment, and an eternity, we would have no authoritative confirmation of these ideas; and compelled by reason to believe them necessary to the harmony and perfection, and just regulation of the universe, we would yet, with Plato, be left to the uncertain hope, that a future revelation, might perhaps show that these deductions of reason possessed an actual objective validity. Or, without hope, we might see the logical necessity of a just, good, and holy God, to the well-being of the universe, and be yet abandoned to the miserable doubt, whether we ever really could know of any such existence ; and whether, despite the conclusiveness of our abstract reasoning, we might not, after all, be cast loose upon a fathomless eternity of wretchedness. Finding ourselves compelled to answer unto our own souls the all-important queries-whence are we, whither do we go, what are our relations to the universe, and eternity, what or who is God, and wherefore do we 
exist, -we would either, following the indications of reason, be compelled with Socrates, to rely as our only authority, upon the general and obscure traditions of the human race; or else, abandoning or contravening the promptings of reason, we would be plunged with Heraclitus, into the cheerless, dreary, horrible, black abyss, of an atheism destructive of all hope, of all that is noble, and sweeping away the very foundations of all morality and all law. It is not enough that we could arrive at the logical necessity of the existence of a just and holy God, the mind would still demand an authoritative confirmation of the deductions of reason, upon which to rest; and without which, even the conclusions which abstractly might seem to the reason necessarily true, would be left in painful darkness as to their actual concrete existence. Take, as an illustration of this, the discovery of the last planet. Le Verrier, in his closet, demonstrated by a chain of mathematical reasoning, the logical necessity of the existence of such a body; but had there been no telescope to reveal the distant mysteries of the heavenly mechanism, the actual existence and motions of his planet must have evidently remained in vague obscurity. And so, reason, in her closet, may arrive at the necessity of the existence of God; but she must linger in obscurity as to her hopes and aspirations and destiny, unless there be the telescope of revelation to confirm her deductions, and to make known the true 
character and will of the Deity. We thus see that the giving of revelation, so far from being strange and unexpected, was earnestly desired and looked for.

But we find from these ancients, whom we justly take as the type of the human intellect in its highest form, without christianity, that man is perplexed and oppressed by other momentous problems, springing from the fundamental one respecting the being of God; in regard to which, he demands a satisfaction which reason alone can not afford. Can this God be propitiated? And will he assist the soul which is laboring to become good and virtuous? Is evil eternal? And triumphant as it so often is, to the wrong and oppression of virtue, must there not come a time when all will be made right, and justice will be vindicated? And reason must determine with Plato, in his books on Laws, that if God be holy and just and perfect, he can not easily be propitiated; for, according to such a character, he must exact retribution for sin; nothing but holiness can please him and secure his favor; while holiness, which can of course avail only during its actual continuance, can not atone for past sin any more than for future. And then, there is the universal voice of humanity, to which Socrates is represented as ever appealing, as to a solemn authority, uttering remembrances of divine teachings, which speaking from unmistakeable instinct, proclaims the necessity of propitiation, confesses the universality of $\mathrm{sin}$, and owns 
a future judgment and an inevitable retribution. There is no point which can be more clearly shown by historical induction, and by a reference to the works of pagan antiquity, than that the universal voice of humanity has ever confessed the hateful and terrible nature of $\sin$, by the universal belief in future retribution and dreadful punishments; and that man has ever been oppressed by the sense of the necessity, and yet the difficulty of propitiating Deity. Thus, in the 9th and 10th books of his laws, Plato, in terrible words, speaks of inveterate, unexpiated sin, becoming a raging disease, calling for vengeance upon itself; and urges the most solemn expiation, if perhaps wrath may be averted, and the wretched disease be made lighter; while he indignantly declares that it is derogatory to the character of Deity to presume that he can be easily propitiated; as though the fount of absolute righteousness and holiness, could be made to change his immutable relations towards sin and justice and purity, by the offerings of the sinner. There was no fact more clearly realized by the ancients, than the universal depravity of inan; and the fearful extent to which a moral corruption, almost inconceivable to us, prevailed throughout the whole social life of the ancients, is mournfully manifested in the startling taint which pervades even their serious and loftiest literature. "It is the nature of man to sin, both in public and private," says Thucydides, in words which, in his $3 \mathrm{~d}$ book, he 
puts into the mouth of one of his historical personages, "no law can restrain him from it. All modes of punishment have been exhausted in the attempt." And he further says, "To speak plainly, it is impossible; and it is a proof of great simplicity for any one to suppose that when human nature rushes eagerly to the attainment of any gratification, it can be turned aside, either by force of law, or any penalty, however fearful."

With such a sense of the depravity of man, it is not surprising that while feeling the necessity of virtue and holiness, in order to please the Deity, these ancients should also have felt the surpassing difficulty of its attainment, and of breaking the bonds of sin without Divine aid. In the 6th book of the Republic of Plato, Socrates is represented as saying "Do you think that any sophist, or any instructions of private persons can control, or even withstand such influence for evil? For it neither is the case, nor has been, nor ever can be, that any character (or state of soul,) should undergo a change to virtue in opposition to the corrupt training of these influences. For we may be well assured that he speaks most truly who asserts, that if anything, under such circumstances, is saved, and becomes such as it ought to be, a Divine dispensation alone hath saved it." And indeed "he pronounces the case desperate," "unless" says he "some God should come to the aid of the soul."

The reason, then, proclaimed its need of Divine salvation, and owned the omnipresence of Divine justice; for hear Sophocles in the EEdipus Coloneus, 
"Bethink you then;

Heaven hath its eye upon the pious man, Its eye upon the sinner. Flight there's none, No hiding place to which th' unholy wretch Can e'er escape."

And Plato also in the 10th book of his laws, speaking of Divine justice, says— "You shall never be neglected by it. You can not, being small, so descend into the depths of the earth, nor being raised on high, so fly up into heaven, but that you shall pay the fitting penalty, whether remaining in this world, or having passed through life into Hades, or having been borne to a region still more wild than these." And amidst these solemn convictions, came upon the mind the universal belief in a hell, which has been one of the oldest and most generally credited articles of belief in the creed of all ages and nations. And reason demanded a solution of all these difficulties. She did not ask a system which would tell her that she was mistaken in all these conclusions; that God meddles not with men; that there is no retribution for sin; no final settling or winding up, as both Plato [Laws, b. 10,] and the New Testament [Mat. 13,] call it,-no day of reckoning, when the great problem of good and evil will be solved, and the character of the universal ruler be vindicated. Whatever individual understandings, severing themselves from the great Consciousness of Humanity, may do; the deep instincts of Human Nature would, with the universal reason of mankind, reject any such system claiming to be a Divine revelation. It could 
maintain no hold upon man, because instead of basing itself deeply within, it would contravene all the wants and necessities of his religious nature, which themselves spring from fundamental conceptions and feelings rooted in the deepest laws of man's constitution. Reason perceived, that hateful as sin must be to perfect holiness and perfect justice, there was needed something greater and more efficient to remove it, with its effects, than man had yet devised. And also, while reason could penetrate to the necessity of some Being to unite and rebind the perfect and the imperfect, the holy and the sinful, the changelessly just and the ever erring, the Divine and the human, who logically must be the synthesis of the two, by being of the nature of both; yet reason could never discover how perfect mercy was compatible with perfect justice, and how incarnate Deity, which in endless ways men ever figured and believed in, could once for all resolve the problems. But christianity proclaims such a character of God as reason felt to be necessary, and displays his attributes and his relations to the universe and man in a clear and divine light, which reason could never have discovered. Confirming the deductions, and meeting the wants of reason respecting sin, holiness, propitiation and judgment, it gives, by the light of the Divine law, a character to sin, of which reason had but partially conceived; it proffers the aid of Divine grace to lead unto holiness, and to save, with a fullness which reason had scarcely hoped; it shows how God may be perfectly just, and at 
the same time equally merciful ; how he is propitiated by an awful sacrifice, which reason, with all her conscious need of propitiation and expiation, could never have devised, could never have dared conceive; it manifests the very principles of Divine justice upon which a judgment will proceed, with a wondrous depth and clearness which reason can not but admire, and feel to be entirely consistent with all that she had conceived necessary for the vindication and elucidation of the dealings of Providence, and justifying the universal fear of hell, by an awe beyond the wildest conceptions of the Poets; it also holds out rewards and bliss, such as reason and imagination in their loftiest and most sanguine flights, never argued, or painted, or dreamed.

To be assured of the favor of God, of hope in the dark mystery of death, and of happiness in eternity, are the most imperative wants of man's spiritual nature ; and it is only necessary to reflect upon the moral condition of the ancient world in reference to these problems, in order to appreciate the priceless value of the answer which christianity affords. This answer can only be fully appreciated in all its boundless consolation, by receiving christianity into the inmost consciousness as a vital power. But even the mere superficial observer can have no difficulty in perceiving the adaptedness of christianity to man's intellectual, moral and social wants, when he contrasts the influence which it has exerted in the elevation, development, and progressive civilization of the world, 
with the condition of theology, morals and politics, before christianity was promulged.

The narrow views of the ancients respecting religion as a ritual service, and not as an inner vital principle, actuating itself in the whole life of man, and respecting the fundamental moral distinctions of race, involving the great questions of right and wrong, of citizenship and of international intercourse, rendered it to them an utterly unresolvable problem how a universal, efficient religion, could be possible. But the central verity upon which christianity rests, affords a profound and sublime solution. Human nature is not a mere aggregate of individual men, it has a certain objective validity as a universal humanity, of which each individual partakes. However it may become peculiar in its modifications as impersonated in the individual, it is demonstrated by all history to possess a unity as nature, through which moral influences flow from originating impulses, as the widening circle spreads throughout the lake from the in-dropped pebble. Here, then, is the deep basis for the moral significancy of incarnation. God has connected himself with this nature, and introduced new moral elements, which place it in a new relation to himself, and to his eternal truth. And upon this fact christianity plants itself as a universal religion, as a new life in man, and furnishes the bond which sweeps away the narrow distinctions of the ancients, by making every partaker of humanity of the same moral race, and thus reducing mere national peculiarities 
to points of difference involving no confusion of right and wrong. In her sublime mission, christianity strives to realize in every sphere of human life, the kingdom of God, and to perfect redeemed humanity for citizenship in an eternal polity. From the imperfectly developed consciousness of childhood, and the secret recesses of the mourner's or the penitent's heart, to the intercourse of man with man, or the high domain of national legislation, there is no region of humanity, no phase of life, where she can not enlighten by her awakening touch, pour the balm of her divine consolations, or guide and purify by her lofty principles, and her God-derived wisdom. No human intellect could have devised a religion of such universal applicability to man, so rooted in the necessities of his nature, and based upon the highest conceptions of his reason. It meets all the difficulties which were felt, and remained unsolved before its revelation, with regard to the possibility of expiating sin, of preserving inviolate, and yet in harmony, the Divine attributes of perfect justice and perfect mercy reconciled with perfect love, and of uniting the Divine holy nature with the Sinful Human; or in other words, since God must be changeless, and just and unjust, right and wrong, must ever hold the same relations towards him, it shows how man can be placed in that state which holds towards God the relation of just, and upon which he looks with favor.

Now when we find a religion promulgated by men who could never have known the subtle reasonings of the 
Grecian intellect, nor, of themselves, have met, had they known them; but which religion meets fully, authoritatively, and perfectly, every want that was felt or could be devised on the most profound subjects, by the loftiest intellects,-intellects which will command the admiration of men to the end of time,- and when we find this religion, not only meeting such wants, but presenting views with regard to them, far more profound and sublime than anything which even Grecian genius ever conceived, we feel an immoveable conviction that such a religion could only have emanated from God. In the light of its overwhelming array of moral and intellectual, evidence, all the objections of the infidel in the lower and narrow sphere of historical doubt, or petty supposed contradictions in the narratives of the Evangelists, fade into utter insignificancy. Suppose that the Gospels were even full of such contradictions and mistakes,- - suppose that the historical chain of evidence, instead of being of adamant, was imperfect; here is the immoveable fact of the existence and power of christianity ; here is its sublimity ; its divinity stamped upon its very forehead, and uttering its resistless voice in the consciousness of every one who steels not his heart against its directions and precepts; and all that the infidel could claim would be, that the history of the origin of christianity had been recorded by incompetent writers. But surely the man with whom such considerations can out-weigh the moral grandeur, the deep adaptedness to man, the infinite comforts and $15^{*}$ 
hopes, which proclaim the origin of christianity from the Creator and Father of mankind, must be but coldly a searcher after truth; or if he be a deep and noble and earnest soul, then to feel compelled to reject such a religion, must render him miserable indeed. No! it is impossible! If such a man be true to his own nobility of nature, the very wretchedness into which such a conclusion would plunge him, must send him to a deeper investigation of the truth, which will leave him no rest, until his spirit finds its home in the bosom of christianity. 


\section{CH A P T E R V 1 .}

THE ORGAN OF RELIGIOUS FAITH.

We now find ourselves brought, by the whole course, along which our discussion has been advancing, directly to the most vital point respecting the manner in which christian truth can realize itself in our own consciousness, and thus afford to our individual reason a verification of its reality. If $I$ must admit the accordance of christianity with the conceptions of reason and the demands of human nature ; if I must admit that incarnate God has revealed a religion whose claims are imperative upon every man; I must make this religion my own, I must perceive its power and reality for my own individual wants, or it will have been proclaimed in vain for me. Its intellectual, historical, and moral truthfulness, may be clearly perceived and admitted; but it is not in these, that its highest value lies. This is to be found in its religious truthfulness; or, what may be termed its self-demonstration to the inmost consciousness of man, as a being who needs a religion, from his possession of a religious element as an essential part of his nature.

Now, the question is, have we any faculty or organ by which we can test or apprehend the RELIGIOUs truthfulness 
of christianity? Or, are we reduced to accept it, on the one hand, merely upon the logical conviction of our judgment; or, on the other, by taking refuge in a mysticism, where reason is lost in mere subjective feeling? We hold that we are not reduced to these two alternatives, which would afford but a basis of shifting sands to the most momentous convictions which human nature can experience, and for which it demands a foundation, immovable as the central fixedness of our own personal identity.

In order, then, in answering these questions, to bring out the point we have in view, with all the clearness in our power, we must examine to some extent, the prevailing views respecting the criteria which an individual can possess for determining the religious truthfulness of christianity.

We now put out of the question, all church institutions, on one hand, and on the other, the piety and religiousness and personal faith of individual christian people connected with any communion. Our objects of investigation are systems, or methods of testing the truth, and the faculties of universal human nature. Our desire is to establish the vital point involved in our answer to the questions proposed, upon a reasonable and philosophical basis. And we hope that this is sufficiently explicit, to obviate misunderstanding, and to exonerate us entirely from any charge of illogically confounding either persons and principles, or institutions for embodying and setting forth the truth, with that conviction and apprehension of 
the truth itself, which must be prior to any argument about institutions.

When we analyze the prevailing theological systems, in order to discover the general principles which form their primary characteristics as systems, and afford a ground for their generic classification, we arrive at a single universal characteristic which underlies the whole of them, although it presents itself in particular systems, under two general phases. This characteristic is formality. By this term we intend nothing invidious, but we mean by it to express the effort to give to christian truth a logical, or an objective form, which appeals to the understanding, or to the emotions.

Under one phase, formality actuates itself in propositions of Divinity, merely drawn by a logical process of the understanding from data directly taken from the Bible; and, under the other phase, it manifests itself in some objective system of tradition, as the mediate guide of the Understanding in the application of its faculties to the Bible. Now the question arises, must we only balance the choice between these two phases of formality, as obliged to accept one or the other, or is there any other answer to be found to the questions which have been started? Before replying, we must analyze somewhat more closely the nature and results of these respective phases.*

* See the whole of our argument treated in the noblest style and with the finest logic, in Morell's Lectures on the Philosophical Tendencies of the Age. 
An individual begins to enquire respecting the great problems of his destiny and hopes, and accepting (it matters not at present upon what grounds,) christianity as a Divine Revelation, he seeks from one of the existing systems a reply to his queries. Ho is furnished with a Divinity, or a body of formal doctrine deduced from Scripture, as an embodiment of christian truth. He asks how he is to test the validity and truthfulness of the Divinity presented, and he is at once referred to Scripture itself. This is a virtual admission of the competency of his understanding to derive for himself the truths of Divinity as contained in Scripture. But he comes to different conclusions from his investigation of Scripture; he finds also a variety of systems of Divinity, widely differing, and all appealing to the logical understanding as the competent judge of their accordance with Scripture. If one holy and learned community, or individual, differs from another in the interpretations which both possess a right to educe from Scripture, the individual must balance their respective claims, and become thus his own authority for accepting one or the other. Or, suppose that he seeks to take refuge in the agreement of a majority; here again, as no majority is found absolutely coinciding in their $\mathrm{Di}$ vinity, the individual must decide what points are indifferent and what essential, and thus once more he makes his own judgment the arbiter. If, finally, he determines to act fully upon the principle of employing his own individual judgment, even if employing all the aids of learning and 
prayer which he can command, should he be led to very new and peculiar doctrines, he is at once assailed and sacrificed at the altar of public opinion, for the presumption of contravening the opinions of so many wise and good; opinions themselves formed upon the very private judgment condemned in the new exerciser of it, and which would have been heartily approved, had it led him to coincide with some of the systems of private judgment, which have obtained a recognition and toleration, that perhaps, in time, his own may also acquire. In short, if the understanding alone is to be the arbiter, then in the midst of the conflicting chaos of diverse systems and interpretations, based upon Scripture, there is no positive standing point to be found, but in the untenable claim of individual infallibility or inspiration; in the determined adoption of one system, and the denial of truth to all others, which involves the most revolting and absurd conclusions as to the very understanding which is so confidently appealed to ; or in the denial of any possibility of attaining a valid hold upon truth, which must plunge us into miserable scepticism. If one is told by a certain system to which he can not accede, that it is because he has not prayed with faith, or is not really pious, or is prejudiced, or not properly enlightened, he may justly reply that these are points upon which no individual judgment has any better right to pronounce than another; that if the understanding is the arbiter, every one must be the final judge, however many intermediate steps are introduced, of what he 
is to accept for himself; and unless we can get beyond the field of the logical and controversial understanding, we are inevitably shut up to the conclusion that truth is merely subjective; that is, that whatever is true for the individual, is the only truth he can know; and in thus multiplying absolute, individual truth, its essential unity is destroyed, and any thing and every thing is equally true. The moment that an appeal is made to any thing beyond the understanding, the whole principle of individual judgment is virtually given up as untenable; although it would be difficult to show, upon the principles usually urged in support of individual judgment, how such an appeal can be valid, as it must itself be judged by that very understanding which it seeks to guide.

And what is the effect of this uncertainty in the direct application of the principle of individual judgment? A tendency to give up all religion, or to attach the utmost importance to certain phrases, or logical systems of doctrine, or peculiar emotions, as the test of religion; and to imagine all other theologians or communities less perfect and profound, in proportion to their distance from this species of formality. Truth, thus brought down into the arena of the understanding and mere emotions, is placed at the mercy of every subtle logician; and although by a sacred instinct, we may hold on to the religious truths which we have found precious to our own souls, even when our understanding and logic are silenced and confounded; yet the fearful results which history shows to 
have followed, in the triumphs of infidelity, indifference and despair, when truth is confined to this arena, warn us against the fatal error of seeking here for the test of the religious truthfulness of christianity.

In being obliged, however, to reject the individual judgment based upon understanding, as the true tribunal in this matter, we do not deny its full validity in its appropriate sphere. We recognize its utility and even necessity, in those matters which belong to the understanding ; and we concede the perfect right of the individual to act upon his clearly formed convictions, which he can only do by the exercise of that judgment. But we are responsible for the intelligent formation of our convictions, and it is not to the sphere of the understanding that the test of the religious truthfulness of christianity belongs.

We turn then to the other phase of formality, and it proffers to the earnest inquirer, perplexed by the contradictions and extravagancies of the principle of individual judgment, a fixed objective guide in an asserted tradition. But upon what principle is this proffer made? If it is made upon the ground that the individual judgment is itself incompetent to decide upon truth, then undoubtedly that judgment must be incompetent to decide upon the claims of the system presented. If authority is attempted to be based upon the utter inefficiency of reason, it can never prove the validity of its own commission, nor even the truth of revelation itself. And should there be different authorities advancing conflicting claims, inefficient 
reason could never decide; and the ultimate conclusion would be that reason could never reach the truth at all, or that the authority under which every individual happened to find himself was the only absolutely valid authority for him. But, if instead of a ground so utterly destructive to any real objective truth whatever, the appeal for the validity of the claims advanced is based upon the admitted competency of the understanding to judge and decide upon them, then, after all, the validity of the authority for the individual, rests upon his individual judgment. Whatever testimony, or arguments, or proofs be adduced, they must all be decided upon by his own judgment ultimately, and thus he is not at all out of the sphere in which the former principle left him. More than this, if his very earnestness in pursuit of truth renders him unable to take things merely upon trust, without assuring himself of the solidity of the grounds upon which they rest, his difficulties will be greatly increased by the enormous demand upon his learning, wisdom and judgment, to decide between the conflicting claims of different authorities. Nor in any possible manner, can he avoid the ultimate step of deciding according to his own judgment of the testimony before him, and thus actually resting the momentous question upon the amount of his individual information, and the logic of his individual understanding. And with what propriety, then, can he affirm another to be wrong, who has, perhaps, bestowed vastly more care and labor upon the investigation, and as the result, has accepted a different 
authority? Put the matter in any possible form, as that God has given such an authority in a certain system, or that the voice of antiquity, of general consent, based upon history and tested by Scripture is the authority, or that Apostolic tradition in keeping of an appointed witness, is a sure objective guide, or put any other theory that you please, and still the question recurs, how can an individual be certified of this? Upon what ground can he receive it, or be convinced of it, but by testimony, argument and proof, addressed to his understanding, and upon which, consequently, he must himself decide; and thus no step is at all made here, beyond that very individual judgment, since the validity of the proffered guide must, for it, ultimately rest upon its own decision.

But suppose that all this be conceded, as it assuredly must be, unless one claims a special inspiration as his guide in deciding; it can then be sald, that while the validity of the authority to you, must of course depend upon the decision of your judgment respecting its proofs and claims; yet, having been once convinced-having once upon sufficient examination and consequent approval of your judgment, made submission to the authority, you are then relieved from all further danger of running into the extravagancies of private judgment; and having intelligently selected your own guide, you may thenceforth peacefully follow its instructions. Even if this was so, another would have an equal right with yourself, to assume the same ground, in coming to a very different decision respecting 
the authority to which he submitted; and without some other authority, some positive, universal, infallible tribunal to which to appeal, the controversy must be endless; for, put it as you will, it is a logical contest of the understanding, and the individual judgment is ultimately the actual decider for each. And yet again, the very claims of such a tribunal must be decided upon by the individual judgment, before they can become valid for the individual.

But, go a step further, suppose that the individual judgment, upon the grounds presented to it, has accepted an authority for itself; is it thereby relieved from all further perplexity of exercise? It still finds a vast field opening before it, at which it may well stand appalled. What does this authority teach? What is the objective, embodied, certain tradition, to which it demands assent? Must the individual wade for himself through the immense mass of documents in which the traditıon is embodied, locked up as they are in learned tongues, demanding the application of great resources in criticism and history? If so, he is then so far from being relieved of the exercise of private judgment, that a greater demand than ever is made upon it. Or is he to accept that tradition as concentrated in a certain formula? But that very formula itself is the subject of such diverse interpretations among its own receivers, that again the inquiring individual's judgment is called upon to decide whom he shall follow; to which class of interpreters of this tradition shall he submit himself? How shall he, amidst the controversies and differences, deter- 
mine what actually was held "always, everywhere, and by all ?" He must either decide it immediately upon his own judgment, or he must accept a certain class of interpreters as those competent to decide it for him, and he can only do this by an exercise and determination of his private judgment. Why does he hold so and so? Because the authority to which he has submitted by a decision of his own judgment upon its claims, teaches him to hold it. How does he establish the fact of this teaching? By a reference to the formula of that authority. But that formula is differently interpreted; how does he establish the correctness of the interpretation which he receives; what is the authority within authority, which determines for him the true voice of the authority which he receives? Is it the majority, or general consent of the writers of that authority? This point is within the sphere of controversy, and still must ultimately rest upon the decision of his judgment. Multiply the steps, vary the theory as you will, and in the ultinate analysis, you are ever brought round in an eternal circle to the individual judgment again. If you affirm, this is the authority one ought to receive. How can you prove it, but by an appeal and argument to his understanding, upon which his judgment must decide before he can admit it. If you assert that one contravenes the teaching of the authority which he has received, how can it be shown, but by an argument, upon which again the judgment must decide to make it valid for an individual. If you set forth this system as universal tradition, 
still it must be so proved to the individual judgment before it can be accepted. And, moreover, the very appeal to what was held in christendom "always, everywhere, and by all," is a virtual giving up of the essential principle of an objective tradition, as embodied authority in a system, because it is an appeal not to an objective tribunal, or to any objective form whatever, but to the subjective convictions of humanity in a certain condition. And if these convictions are only regarded as attempted to be realized in a fixed, objective form or system, then again criticism, individual judgment, must be applied to determine what really is included in this comprehensive rule. Besides, if in this latter sense it be applied to all christianity in all past ages, and in the present inclusive, it can only hold good by stripping away every thing of disagreement, which would by no means leave a certain, fixed system, as an objective authority. If it be applied to past ages only, what period is to be assumed as that within which it is absolutely valid? And how is this to be determined? In fact, the principle can only be significant in two ways; either as confined to the tradition of a particular community, when, as different communities present different traditions, the whole question, as to which is the authority to be accepted, must be re-argued, and again we get back to the decision of the private judgment; or it must apply merely to what reason perceives to be the general vital subjective convictions of christianized humanity, which takes, indeed, the whole matter out of the sphere of the individual judgment, but 
also at once destroys the application of the principle to prove the existence of any objective system of tradition as embodied authority. Thus we are compelled to conclude that this phase of formality, no more than the other, affords the test of the religious truthfulness of christianity, since, with all the steps which it introduces, it does not, in the ultimate point, remove us from the sphere of the logical understanding and the private judgment.

In short, to accept an authority giving a tradition, and to determine what is its interpretation of that tradition, must rest back ultimately, either upon the pretension to direct inspiration, or upon the decision of the individual judgment, and as we actually find that the subjects of an objective authority and tradition in christianity, are involved in endless controversies, - even within the sphere of the very systems which proffer them as fixed guides; we must either give up as hopeless the possibility of absolute truth, or every man must take his own system as his authority; or we must get to some objective and infallible authority, which has a plausible claim, by its extent, grandeur, antıquity, and fixed, central headship, to be the absolute tribunal. And even to this, we would have to submit by an exercise of individual judgment.

In thus endeavoring to show what tradition can not do, we have no disposition to depreciate it, in its own appropriate sphere. As a historical and interpretative element, it possesses a value which can scarcely be estimated too highly. But to attempt to make it do that for which 
it is so evidently incompetent, must have the fatal effect of driving many a logically consistent mind into the withering arms of scepticism.

The reason why neither of the phases of formality we have been considering, can supply the desideratum sought, is because they appeal merely to the understanding, which can furnish no material of knowledge, but only the logical forms in which knowledge can be expressed. And here, we are ever in the sphere of controversy and individual judgment. The Bible and christianity, are not given as mere data to be worked up into systems by the understanding, applied either immediately or through tradition; but they are given as elements of religion, appealing directly to the deepest spiritual consciousness of man's religious nature. Hence the great question again recurs, have we any faculty or organ by which we can test or apprehend the religious truthfulness of christianity?

That we have, is exactly one of those facts which carries its own demonstration with it, in appealing, not to the logical understanding, but to the inmost self-consciousness itself. It can be involved in no controversy which does not strike at the very essential moral convictions of the soul itself, and the very integral elements of man's religious nature. It can only be shaken by the same denial which rejects intuitive truths, and strikes at the very existence of reason as an absolute faculty of the soul. No argument addressed to the understanding could prove that man thinks; it must presuppose the very fact itself, 
lying so deeply within the direct sphere of intuitive consciousness as to be beyond argument, before any argument could be erected. And so with regard to moral and religious truth; before any argument can be adduced respecting them, it is necessary to presuppose an intuitive faculty for their direct perception, antecedent to, and far deeper than the region of logical proofs and argumentation. Just so, a man may take all the scientific elements and formula required, and construct a theory of music, which shall be valid for the understanding; he may take a great composition and prove that it is scientifically composed according to that theory; but he could never, by any such logical processes of the understanding, convey the remotest of those conceptions, or awaken one of those emotions, which spontaneously flow from hearing great music actually executed. And however learned he might be as to the theory and science of music, if he possessed no power in his soul of appreciating harmony, if the sublime strains of the greatest masters fell upon his ear, as no more than sounds, which spoke no moving language to his consciousness, other than the most ordinary noises of daily life could speak,-how utterly futile would it be to attempt to prove to him that there was a power in music of which he could not dream. The most unscientific hearer who possessed an intuitive perception of the glorious mightiness of harmony, would see that in music, which he, with all his science, could never perceive. And it would be superfluous to attempt to prove 
to such a hearer, that music was mere empty and unmoving sound. His own consciousness would lie deeper than any formal argument could reach. It is precisely so with the religious truihfulness of christianity. It appeals to no process of the understanding, it submits itself to no decision of the individual judgment, but it at once enters into the sphere of reason and presents itself immediately and directly to its intuitive perception; and, as religion, it actuates itself in the spontaneous consciousness of that nature to whose inmost wants it is adapted.

It is the office of the reason to give us truth directly, to furnish us with those immediate intuitions which are the necessary basis and essential elements of all knowledge and logic, and which must therefore transcend the sphere of the understanding, in carrying with them their own proof by virtue of their very necessity. The understand- . ing can give us nothing but forms of thinking; it can only act upon data furnished it, by working them up into abstract propositions, and all those processes commonly called reasoning. But reason at once gives us truth, not abstractly, but actually, face to face, as it were. It is thus that it gives us the necessary material of all geometrical and pure mathematical truths, which are beyond the proof of the understanding, because they are intuitively perceived to be necessary, as that which reason can not reject without self-contradiction, and which are absolutely necessary, in order to render any process of the understanding itself possible. It is thus also that 
reason gives us the necessary conceptions of moral and religious truth, and it is to reason directly that the religious truthfulness of christianity manifests itself. It plants itself immediately in those great moral and religious intuitions and feelings, which alone render it possible as a religion for universal man; and it elevates, purifies, enlarges, and directs those conceptions and emotions, until they all harmonize in the energetic operation of the will, uniting and yet subjecting the whole being to God in the personal Redeemer. Christianity, as religion, thus carries its own demonstration to the intuitive reason and consciousness of man, and thus actuates itself in the individual as a life, - not as a divinity of the understanding, and in christianized humanity as the vital, organic growth of a living principle, - not as a system of formality.

In the most ignorant man, you are sure, that there is that potentially in his reason, which, however dark and dimly recognized by himself, yet when awakened and developed, will afford the material upon which his understanding can work for his advancement in mathematical science. And so, likewise, there is that in his reason and feelings, involving the intuitive conceptions and emotions of religious truth, which, when awakened and developed by the vital touch of christianity, will enable him at once, to perceive absolutely its truthfulness, as adapted to his whole nature, and to connect himself, through his own consciousness, with the great living consciousness of christianized humanity, as it has flowed through every 
age to his own; and thus he will know the truth of that life, which his understanding alone can never establish or reach, but which flows from God, and permeates the christian consciousness of man. The actual reality and development of this life in the world, and consequently of the intuitive consciousness in which it is rooted, is an undeniable fact which no scepticism can overturn. And, it is only upon the reality of this fact, that any argument, respecting christian institutions, as means of fostering and developing that life, can be intelligible. And assuredly, if the whole history of Christian Consciousness for Eighteen Centuries be not an utter delusion,- - a delusion which must invalidate all mental phenomena themselves,- - then do we hold an impregnable position whence to show, by indicating this great truth of man's central being, that there is a ground whereon to place the reality and divine power of christianity, upon a basis as immoveable and indestructible as the essential and immortal nature of the soul itself. Truth is omnipotent,-it is guided upon its resistless and eternal march by the hand of God, and the earnest lover and pursuer of her divine path will rejoice, in rising above the contentious field of the ambitious understanding, to the region of immutable and eternal verity, in the sphere of reason, where alone he can find an adamantine chain, linking his deepest convictions upon the most momentous subjects which can agitate him, to the moveless, everlasting throne of God himself. 


\section{H A P T E R VII.}

THE SCRIPTURES.

By coming, as we sought to do in the last chapter, to the faculty, whereby we can realize the religious truthfulness of christianity, we have arrived at the point of unity, whence the harmony of our whole discussion, through its various phases, is able to manifest itself distinctly. For if we start, on one hand, from the conception of God, we are led to conclude that he must have a special will with regard to man, which leads us to expect a revelation; and finding christianity claiming to be that revelation whereby God has connected himself with humanity, we find in the deepest moral nature of man, the test of the truth and power of that revelation; a truth and power becoming manifest through the christian life, which has ever developed itself in the universal christian consciousness, at once bringing us to the realization of eternal verities, and into immediate connection with God in a personal Redeemer. And if, on the other hand, we start from the fact of the phenomena of the christian life, we are led to a revelation, which carries us up to God, entering into and connecting himself with the immediate sphere of man's reli- 
gious consciousness. No possible appeal to the understanding-no exposition of doctrine-no system of interpretation or tradition-no objective institutions, can furnish that spiritual perception of religious truth, without which, the Bible and the Church themselves can speak no living realities to the inner man. But when the personal consciousness is awakened to its own wants, and the intuitive reason is elevated to the direct apprehension of eternal truth, then christianity bears its own demonstration to man, by the power of its divine life in his soul-a demonstration transcending the ability of the understanding to give, and the strength of logical scepticism to shake. To take an illustration of this : every æsthetical theory must be based upon the antecedent idea of beauty as a conception springing from the universal intuition of humanity; and if this intuition be as yet unawakened in an individual reason, the most logical organon of taste could never itself remove the veil from the Universe, and display it to the individual consciousness, (not as a mere perfect machine, but) as radiant with the in-dwelling ideas of beauty and harmony, with which Deity has in-formed his glorious creation, and which it is ever striving, as it were, to actuate in its rhythmic processes. And just so, no logical Divinity could ever reach those deep moral perceptions in man's central being, within whose sphere religion plants her sacred life, elevating the reason of christianized humanity to perceive intuitively the mighty truths, which God manifested himself in the flesh to reveal, and which the reason of hu- 
manity has been rendered capable of perceiving, by the fact that that very manifestation has placed human nature in a new connection and relation with God and everlasting truth?

There is as surely an universal voice of Christian Consciousness, as there is of the universal common sense of humanity; and to deny that man does possess such an organ for the apprehension and test of truth, must plunge us into an absolute abyss of unlimited scepticism, where the soul will be tossed in an endless vortex of uncertain opinions-will find every imagined resting place fade beneath her weary foot like a changing cloud-and will be driven from one delusive hope of certainty, only to find another distant promise of some rock of truth, sink at the approach of her longing investigation, into the wild chaos of doubt and controversy, until with exhausted pinion she sinks helplessly into blind and unreasoning superstition, or into the icy, black and fathomless pit of all-devouring atheism. It will not do to tell the earnest soul-that soul to whom the longing for truth is a passion-to whom the desire for it in moveless certainty that it is attained, is the deepest, most imperative want of its nature-to whom life is but a worthless bauble without that certainty, and who would give up life itself for that priceless treasure; it will not do merely to tell such a soul, that it must believe because God has spoken. This is precisely its keenest difficulty. To believe, is its most necessary element of life; and to know certainly that God has spoken, and what 
he has spoken, is just the most precious boon which it demands. And how is this to be verified to it? By going around the endless circle of controversial argument, appealing to the understanding? Delusive hope! It needs something deeper, more universally valid than that: It will rather, with Socrates, take refuge in the common voice of humanity, or in the common consent of all good men. And is it possible to believe that God would make man to fight a battle with destiny, and so full as he is of deathless longings, but leave him, nevertheless, like Godless brute? ls there no certain truth, beyond the subtlety of the logician, in the soul-universe of the God of truth? Shall God make souls able to long for truth, to know right from wrong, to fight for good or evil, and leave them natural atheists and helpless strugglers, in a dumb, phenomenal world, that can tell no one what is truth, and that lands every one in eternity, where all must be truth? Shall God make the soul, by the necessities of its own being, look up and ask for truth, and then mockingly sport with it, in giving no answer but hopeless blindness, or an answer of whose truth the soul could never absolutely assure itself, but for which it must depend upon the mere argument of the understanding, and the decision thereupon of its own feeble judgment? Monstrous, impossible paradox! This might the Devil do-but God, never! Look into man's religions, when man had corrupted the original revelation, and see what gleams of saving, helping truth were yet left, in mercy, for his necessities. And when God, in his own infinite 
love, had taken pity upon man, struggling with destiny in dim twilight, and gave him still a fuller blaze of revelation in christianity, look how every straggling prophetic gleam of truth was there gathered up and verified, and how $\mathrm{Pa}$ gan reason in her highest efforts, had been ever guessing and pointing at what Christ confirmed, illustrated, rectified and fully manifested.

It is not to the understanding that christianity, as religion, appeals; before this tribunal, her historic evidences, her institutions, the consistency of her formal doctrines, submit themselves it is true; and they are defended by a panoply of argument, which invites and challenges investigation. But she presents herself in her vital power, as a voice from God, directly to the reason or intuitive consciousness of man, in which are already those indestructible moral convictions, whereby he can at once perceive the truthfulness of christianity, in its accordance with the voice of God in his own conscience,-in its elevation of those religious ideas which God has implanted as necessary in human reason-and in its satisfaction and purification of those emotions which excite him to look for help and salvation to the Creator, who is their real object; and actuating itself in him as a pervading life, it connects him with the whole intuitive consciousness of christianized humanity, and thus gives him the same absolute certainty of christian truth, which his connection with the universal reason of mankind gives him of the reality of harmony or beauty. Without doubt, this high verity of christian truth, 
can never manifest itself to an individual, so long as he is shut up within the narrow circle of prejudice or sensuality,--so long as he seeks to verify every thing by the mere understanding, - and so long as he probes not his self-consciousness deep enough to recognize the contents of reason and conscience. But, in proportion to the unclosing of his inner eye, will truth beam more fully upon his intuitive consciousness, and strengthen, and purify, his clear perception of her divine lineaments, as she has ever shone with growing lustre upon the wise and good. And as his spiritual vision becomes keener by its continued contact with truth, so will his understanding become clearer in its reception of just data and deduction of valid conclusions; and he will ever find the individual peculiarities of his personal reason, merging more and more into harmony with the universal reason of cliristianity, and thus identifying him by that unity of truth which underlies all minor errors and differences, with the living consciousness of "the holy Church throughout all the world."

We have now attained a standing point, whence the true majesty and grandeur of the Bible can be perceived, rearing itself far above the narrow sphere of controversy and objection. We have not now to descend into that arena, in order to prove the genuineness and authenticity of that volume; because the fact, that all christendom has ever received it as containing the books which christians regard as written revelation, is as undoubted, as that the Vedas have ever been the acknowledged Sacred Books of the Brahmins, or the 
Koran, that of the Mohammedans. And every religious community is certainly the most competent witness as to what it does believe, however unfit it may be to pronounce upon the truth of its creed. But the christian life, is also as absolutely certain a phenomenon in the history of humanity, as is the existence of any other intellectual and emotional phenomena whatever in human nature. This life can only be explained by a Revelation of God, and the awakening of man's intuitive consciousness to the direct apprehension of the religious truthfulness and power of christianity. And hence, the universal christian reason is a competent perceiver of the true value of the Bible, as a written revelation. That reason has ever recognized in it moral, religious and spiritual elements, flowing from inspiration, elevating and enlarging man's intuitive faculty of apprehending truth, and appealing to his deepest consciousness. And it is exacily the competency of the Bible to do this, which places it upon so sure and lofty a basis. With no organ whereby to perceive its inspiration, it could not appear different from other books; and this organ is necessarily that whereby man can test-as was endeavored to be shown in the last chapter-the religious truthfulness of christianity. It is to this that the Bible appeals. It was not given to furnish data, wherefrom the understanding might construct systems of Divinity ; for an individual might construct the most logically acute and perfect system, and be thoroughly versed in all philological criticism, and yet be entirely ignorant of that deep truth and power, 
which make the Bible a living word. It does not give us truth in a formal, abstract and systematic manner, but practically embodied. It is the product of minds whose intuition of spiritual truth had been awakened to an amazing degree by God, and whose writings are therefore pervaded by the spirit of their inmost experience, and by the Divine ideas which illumined their reason. And the Scriptures are given to appeal to and awaken the same faculty in man, that he may be more and more able to see immediately that absolute and vital truth, which eternally lives in their sacred pages, beneath the veil of the letter. Given for this great moral and religious purpose, which christianized humanity has ever found them able to fulfil, how immeasurably above all disputes as to mere verbal criticism, do the Scriptures stand. The few and feeble attempts to fasten moral discrepancies and contradictions upon the Gospels have so signally failed, that it would argue great moral obliquity of conscience in any one who should pretend to revive them. The exalted standard of morality and religion, which the world expects and demands from those who profess to take those books as their spiritual rule and guide, is a splendid and instinctive homage to their sublime and consistent model of holiness. And when the intuition of an individual has been awakened to perceive the true object of Scripture,-its manifold "adaptedness to unfold the spiritual life of man,"*-to meet the

* See Trench's fine Hulsean Lectures on this topic. 
deepest wants of his religious nature,-to kindle his apprehension of the Divine truths which breathe life throughout its burning pages,--to raise him into the region of holiness and communion with God,- to ennoble and sanctify his whole being by vital ideas, commending themselves with resistless demonstration to his highest reason and his profoundest emotions; how utterly insignificant appear the paltry discussions, whether a certain act of Jesus occurred, according to one writer, as he was entering, or, according to another, as he was leaving a certain town ; whether a date, or a name, was mistaken; whether a prophecy be accommodated or not; whether different witnesses relate the same event diversely, according to the universal law, that facts strike beholders from different points of view, and in their relation become tinged by the subjective conceptions of the narrator; or, whether, in short, the human element appears more or less conspicuously, in writers who have ever approved themselves to the awakened consciousness of universal christianity, as the utterers of truths which have flowed directly from God.

Since the very phenomena of the christian life proves the reality of the existence of spiritual intuitions in man, no one is competent to pronounce upon the inspiration of the Scriptures, in whom those intuitions have not been awakened by the unclosing of his spiritual vision, any more than a man, in whom the powers of natural vision are pur-blind or feeble, can be competent to pronounce a 
judgment upon an object beyond his range of perception, or too lofty for his inexperienced gaze to reach. And perhaps it is not going at all too far to affirm, that every alleged contradiction and discrepancy which the sceptical understanding has ever imagined that it discovered in the Bible, might be admitted as not worth a discussion, without thereby even beginning to trench upon, or reach the lofty and impregnable sphere, within which the mighty truths and revelations of Scripture are enshrined as a veritable word from God. Not that such objections can not, for the most part, be shown unable to maintain their ground, even in their own selected sphere of the logical understanding, but that this, of itself, is insufficient to establish the inspiration of Scripture. The genuineness and authenticity of the books may be vindicated; their consistency and honesty be established, and yet many theories remain, whereby to elude any conclusion from these arguments, as to the higher element of Divine inspiration. This must be carried to a superior and more unerring tribunal, even the awakened consciousness of the spiritual man. And there the reason and religious nature of humanity, in direct contact with universal and eternal truth, intuitively perceives the deep unity of scripture in its manifold and diverse phases; the wondrous unfolding of a Divine idea, through the most various and differing peculiarities of time, place, writer and idiom, yet still in unbroken, and progressive, and ever loftier swelling harmony; the exhaustless fullness of its vital springs, for 
every degree of moral and religious development and capacity; its infinite energy as an instrument of educating and enlarging and empowering the reason and consciousness of humanity; and its resistless self-demonstration to the spiritual nature of man, as a living voice, uttering in the multitudinous strains of an eternal harmony, conceptions linked in one mighty and pervading plan, whose grandeur and execution could only have sprung from the mind and power of God.

These are elements in Sacred Writ which cavil can not reach ; to which philological criticism can not attain, and which have given, and alone account for, that universal influence over mind in every degree and in all its products, which no other volume-no, not all libraries of volumes-can be found to have ever exerted, and which so abundantly justifies for this volume its eminent title of "The Book."

With these views of the object and nature of scripture, it is evident that no historical, chronological, or scientific discoveries, can ever have any bearing whatever upon the vital question of inspiration. They must all move in a lower sphere, and the errors or ignorance of the ancient writers of the Bible upon points connected with merely temporal matters, or progressive discoveries of modern science, can have nothing to do with their enunciation of eternal, moral and religious verities, which commend themselves for their Divine truthfulness to the intuitive reason and consciousness of universal humanity. From 
this point of view it is that the extraordinary profundity of Scripture manifests itself. To turn to it from the perusal of the sublimest efforts of Grecian genius, impresses the truly philosophical and awakened mind with the deepest conviction of its inspiration. Truths, principles, laws, appealing at once to the deepest and innermost intuitions of man's reason and spiritual being, leave no possible doubt of their enunciation having proceeded from God. It was under such guidance alone, that writers in different climes, ages, and conditions, with every variety of style, individual peculiarity, and power of language, and with the most diverse tongues, (what can be more different than the genius and idiom of Hebrew and Greek?) could invariably, with the accuracy of unerring instinct, have chosen the most philosophically appropriate terms and expressions for conveying or nourishing religious ideas, with a profound precision and unity of design which is absolutely miraculous. But without at all consenting to mingle lower matters in the primary question of inspiration, we may allude to the fact that with the progress of science, the language of the Bible has always been found capable of accommodation to scientific demand. Astronomy, geology, have battled every inch of ground against the narrow system of interpretation which would impose the deductions of some particular age upon the whole world, as the word of God. Men assume that their interpretation is absolutely correct, and then put it forth as inspired truth, hedged about with all the awful 
sanctions of God's own words. But science compels them to abandon their position, and drives them to the alternative of denying the inspiration of Scripture, if they insist that their untenable interpretation is what alone the language of the Bible can mean; or, of confessing that the interpretation was wrong, and thus by holding the meaning of Scripture subject to the yet unknown discoveries of science, insinuating a serious doubt as to the value of an inspired record, which can be made to mean any thing that the state of scientific advancement for the time being, may demand. Geology has fought its battle; the question of the unity of the race is now fighting its; and other questions of authenticity, genuineness, antiquity, chronology, and history, will have to fight theirs.* And then it will be recognized that the Bible was never intended for other purpose, than for the spiritual nourishment of the soul. Amidst all of the characteristics inseparable from writers of ancient times, it will be recognized that there is a loftiness of conception, a nobility of idea, a grandeur of language respecting God and religion in those books, which distinguish them from all others, and which present the broad and deeply marked evidences of revelation. Suitable as the Bible will ever be found, (in a degree which all the other books in the world can not approach,) for kindling religious ideas and feelings, and giving such exalted notions of God and

* See Appendix C. 
Duty, and Holiness and Futurity, as would not be attained without it, it will be more clearly perceived, as it becomes less complicated with questions of science and criticism, that the moral intuitions and religious consciousness of the writers of that Sacred volume were awakened by God to a supernatural degree, and the practical value of the Scriptures will thereby become more justly appreciated. And as christianity does not depend upon historical facts and evidence, but upon experience of the religious life, so also christian doctrine does not depend upon the logical interpretation of the Scriptures, but must be determined by what are the practical, experimental facts of the.spiritual life, grounded upon realization of reconciliation to God through Jesus Christ.

But while we thus hold that as an eternal book for all ages, the interpretation of the Bible must not be shut up to the prevailing opinions or science of any age ; but that with increasing knowledge, its language will still be found coincident with the truest demands of science, as we shall ever learn to apply a more enlightened and enlarged interpretation; we repeat, most strenuously, that the true test of its inspiration can not be found in any mechanical view of the fact, but in its adaptedness to the universal, moral necessities of human nature, and in its embodiment of living ideas, which ever awaken and enlarge the spiritual intuition of man, and, like christianity itself, actuate themselves in the vital consciousness of the Church. And, we confidently leave it to every earnest votary of truth, who 
has ever felt the difficulties and the necessity of a philosophical ground for the whole question, to say whether the view which has been suggested, does not place the whole matter upon the loftiest and most impregnable basis.

If upon the all-important topics which have been presented in this discussion, there is any absolute and everlasting truth to be obtained,-any immoveable and certain satisfaction for the soul,-if we are not the wretched, blind sport of chance or destiny, left orphaned in the midst of evil, and helplessly tormented by most cruel mysteries; but if we are the children of a wise and merciful Creator, the accountable creatures of a sovereign Deity; then assuredly does revelation appeal to our highest reason, our inmost consciousness, and our indestructible moral convictions, for the truth of its declarations, and the sanction of its demands. But if there be nothing within us to re-echo its voice, - to recognize its truthfulness, - to test it by intuitive perception of its divine veracity, - then no historical testimony, no logical Divinity, no traditional witness, can save the dearest and most momentous truths from succumbing before the withering blast of scepticism. Each one possesses in the depths of his own soul the power of knowing the truth of christianity. There is a spiritual vision which may be awakened in every man; and it is not argument addressed to the understanding which religion needs, - it requires only to be perceived by the eye of reason, to be at once intuitively recognized as true. While this saves us, on one hand, from super- 
stition; the universal voice of Christian Consciousness will save us, on the other, from mysticism; and since that Consciousness manifesting its spiritual intuitions in the christian life, is a fact and testimony as undeniable as it is remarkable, it may well excite serious inquiry in any sincere pursuer of truth, why-in case it be so-his individual perceptions and consciousness, are, as yet, separated as by a gulf from those intuitions whereby religion conveys its own demonstration.

Having thus, in the necessary conceptions of the Speculative Reason and in the deep centre of the Personal Consciousness, endeavored to establish a solid basis for religious belief, our discussion finds the termination which was proposed for it; and imperfectly as it has been executed, if it shall have awakened new or more earnest reflection upon the great truths of christianity, and have helped towards the unfolding of the wondrous powers, whereby our souls can apprehend that divine truth, in the realization of which we can alone find the full harmony of our being, it will afford abundant recompense for having written. If, however, we have failed in these objects; the attempt itself was no unworthy one, although beyond the feeble powers of the writer. And one lesson at least we all may bear in mind, that in the great battle of life, in the vast contest between good and evil, in which all are implicated, while time with resistless current is sweeping all into eternity; the soul has one accountability-to struggle-to do ; and sink or swim-live or die, in the world-wrestle,- 
God, Truth, Duty, are the inextinguishable beacons of the earnest soul, which, if it is even overborne and fails of its lofty aims in this life, yet hath its might in faith,ever uttering as an eternal and sustaining melody in the inner being - that in eternity all will be reconciled, and that even the conquered soldier, who nobly fought, will be crowned as victor with amaranthine diadem. 



\section{APPENDIX.}

\section{APPENDIX A.}

NOTE TO PAGE 31 .

Scarcely any thing can be more injurious to christianity, than resting its defence on insufficient grounds, or urging that as demonstration, which no extraordinary acuteness perceives to be a mere petitio principii. The timid and intolerant jealousy with which some regard every probing of christian evidence, appears to argue some lurking craft-motive for wishing christianity to be maintained. Now, if it be false, in the name of the Great Fountain of Truth, let it be speedily exposed. If it be divine, rather let us encourage every investigation, and give the freest scope to conscience and to criticism, that the imperishable gold may shine more brightly by every trial. The frequent want of a deep and mighty conviction of the power of christianity, realized in the inmost experience, is evident from the fact that many hold christian truth on such shallow and slight grounds, that the apparent demolition of the essential historical validity of the Gospel narratives, or even of the inspiration of scripture, by some sophist whom they could not answer, would fill them with consternation, and tear from them all upon which their hopes and religion were centred. But it may safely be affirmed, that (futile as such efforts must be) should these results be brought about, in the general .opinion of the age, by a criticism and science which dares all things, yet no true believer, who had realized in his own soul the deep wants of his nature, and the adequate response which christianity afforded, could be shaken from 
his faith in its divine consolations and impulses; because he knows them to be real, through the direct perception of his intuitive spiritual consciousness. And, through this, he is in sympathy with the whole christian consciousness of every age, and thus knows, that explain the Gospels as you will, yet the christian life in man has ever existed from the time of Christ, derived from him, and thus propagating a living and experimental testimonial of his divine work on behalf of the world. By this awakened spiritual perception, (which is guarded from running into mere mysticism or fanaticism, by the universal consciousness, or "communis sensus" of christendom, he discovers the vital truth of scripture, and its divine power, which will stand against all the efforts of scepticism. Christ lived, the divine manifestation of Godhead in humanity, whose mighty doctrines have ever lived, ever taken hold of the conscience and life of christendom, and now actuate themselves in the believer's consciousness ; and, however his philosophical conceptions may be exalted and purified to recognize the vital truths hidden under the dogmas which are necessary for the church-which are indeed the tangible embodiment, as it were, of the understanding of each age, striving to give logical expression to the christian consciousness, and therefore of real validity, as the approximate exponents of universal truths; - - his connection with Christ, through his own experience, will render it utterly indifferent to his redeemed. soul, full of hope and faith and conscious life in God, whether the speculatist doubts if more or less be known of the details of his Saviour's life, or if the ancient histories of the Jews be more or less traditional and mythical. No mere historical argument ean convince, or preserve from infidelity, a man who has no intuitive (or experimental) perception of christian truth; and he who has, can not be shaken by the bodiless ghosts of scepticism. History and its evidences can never make men christians. They must be awakened to a sense of their own spiritual needs; and when the religious sensibility is awakened, they will intuitively perceive the truthfulness of christianity and its adaptedness to the religious na- 
ture of man. And, if men were more alive to this deep spiritual life in Christ, and rested not upon the surface supports of mere history and dogmas, they would less fear the progress of criticism; and knowing that the christian life was derived from, and sustained by God, they would very calmly, and without clamor, listen to, and gladly accept every thing which science and criticism could justify, feeling assured that the progress of philosophy must involve the progress of truth, and that if philosophy could strike from the canon of inspired books two-thirds of the Bible, it could never thereby touch the truth of christianity, which lives in the consciousness of the indestructible church of God. The man, who in the depths of his own conscience has attained no realizing sense of the living God, and the Omnipotent Redeemer, and the sustaining Sanctifier, but who, instead, believes in some abstraction of attributes and names, and historical facts, and divinity dogmas, may well be alarmed, and feel as though his whole religion was at stake, when the dry bones of his skeleton of faith are crumbled by the vigorous blows of rationalism or philosophy. But he who is awakened to, and in-formed by the divine power of the life of faith in Christ, is panoplied against scepticism, though every Gospel were proved a mere memoranda of traditions, and every Hebrew book, a compilation subsequent to the carrying away unto Babylon. If christianity indeed, merely consisted in a system of dogmas, and not in a divine life, then might there be some ground for apprehension; but the mass of christians have never examined the historical or dogmatic spheres-these enter not into the elements of their belief, which rests upon experience, spiritual perception; and all which they receive on those other points, is taken, they scarce know why, upon the dicta of their teachers. These latter, themselves, are generally among the worst reasoners, and least generally informed, of all professional men. Accustomed to dogmatize and not to be contradicted,-used to respect, and to setting up figments of straw, which they utterly demolish in the pulpit, where no reply is possible; and not obliged, by contact with the keen wit of the world, to be brought 
ever up to the bar of logic and common sense; and very limited, generally, in their reading-that is, not in its amount, but in the narrow sphere to which it is confined-there are few of them who have not themselves taken their information on history and dogmas, from very secondary sources; few who can judge of the trustworthiness or real value of those sources; few who can even criticise the scriptures in the originals, or judge of critical apparatus brought to bear upon them, and upon history ; and who thus merely take at second-hand, what they give to others; and who, after all, must admit that it is upon the christian consciousness-the life in Christ-that the propagation of christianity and the vivification of souls must depend, and not upon theological learning. It is thus that the scriptures, as inspired records, come to us upon the overwhelming testimony of the consciousness, the experience, the spiritual perception, of the church universal ; a testimony we can only fully appreciate, by being in sympathy, or rather vital connection with that consciousness, through our own spiritual being. 


\section{APPENDIX B.}

\section{NOTE TO CHAPTER VI.}

THE mass of mankind can never be brought to laborious and scientific thought, because they necessarily live in the material, and objective world, occupied with affairs which pertain to the surfacelife of humanity; and thus, either know not, or look with suspicion upon the deep, interior, subjective world, in which lies the region of abstract thought. Hence, they deal not with ideas, except in their tangible presentation; and they require abstract principles to be made definite in measurable form, in order that they may comprehend and believe them. For instance, the mass of mankind attach no conception to the abstract idea of law,-they only reverence it in statutes and ministers of justice; they have no conceptions of right or morality, except as embodied in precepts and prohibitions; and hence the tendency to look for, and reduce great abstract truths to their exponents in definitions and dogmas. It is from this fact, as to mankind generally, that there will arise the objection to the principle supported in the VI. Chapter, of its being indefinite and impracticable. It will be said, that it is not possible to appeal to the universal christian consciousness, because it is impracticable to ask every christian individually what are his feelings; and that thus it will only amount to what each one thinks is that general consciousness. In the same manner it will be objected to the principle of there being a higher reason which gives us truth intuitively, that it is indefinite and of little value, because it does not tell us whether the doctrine of such or such a dogma in divinity, is true or not. It is very true that it can give us no such information; but if it could not give us the ultimate, general, and necessary intuitions of right and wrong, of God, moral duty, and religious feeling,- - then, in vain would any divinity appeal to us, or any system of religion attempt to establish itself. As to the appeal to the general christian con- 
sciousness, whatever indefiniteness or difficulties attend it, they are incalculably less than what attend any other principle of certitude.* An individual who believes in christian truth, and sets to work to discover what definite doctrines are revealed in scripture, if he did not think it worth while interrogating every christian as to what he found in scripture, but with such literary helps as he could command, formed his independent conclusions ; - must either hold his own judgment to be infallible, if he determined all to be wrong who differed from him; or, if he admitted that conclusions different from his own, might possibly be equally correct, would either be led to think that absolute truth could not be known, or that it made little difference what conclusions were arrived at. If he shrank from all of these consequences, and held merely that every one must be persuaded for himself, he would leave the whole matter in great uncertainty; and if another applied to him for the truth, and could not be persuaded by his arguments that his views were as accordant with scripture as some other person's, he would have no criterion to which to refer, and the consequence would be the most painful disseverance among christians holding different conclusions, and the direct tendency to scepticism, as to any absolute universal christian truth at all. It is most illogical to say that my view of christian doctrine is true, and yet to shrink from the conclusion that all others are wrong, while I nevertheless refuse to allow that the differences are unessential. If the first conclusion is accepted, every one who differs may say the same, and no absolute truth is attainable ; if the differences be admitted to be unessential, then essential christian truth does not lie in specific, formal dogmas. If I apply to one individual [or church] for christian truth, and he gives me certain dogmas, which another christian [or church] dissents from, and gives instead a different system; and I am then told, "you must decide for yourself;

\footnotetext{
* This word is used, because the word certainty is already appropriated to and associated inseparably with, the idea of what is absolutely known. "The principle of certainty," would mean the principle on which something is already positively known; " the principle of certitude," is the principle upon which certainty may be reached.
} 
the matter is important, embracing essential truth; but each one must be judged according to his own determination ;" while neither party affirms that he alone is in infallible possession of the truth, although he will not allow the other to be right, or the difference to be indifferent; I am compelled to believe that no certain truth is attainable; that the differences are unessential; or that absolute, material, ehristian truth, lies in a very different sphere from that of disputable formal dogmas.

The reference to a particular church authority as the criterion, only complicates the question, without settling it. The proof of authority must rest for its acceptance upon individual judgment. Christians differ upon this matter, even within their own church; how, then, is an individual to settle it? Testimony to be valid, must be such as will approve itself to the common sense of men; but a church erects itself into a special tribunal,-calls testimony, which it interprets for itself, and which the common sense of all christians does not admit; and thus, again, the inquirer is thrown upon doubt, his private decision, or some more general criterion.

An individual affirms such and such positions to be "sound" or "unsound," because they agree with or differ from Scripture; that is, from his interpretation of Scripture; another individual affirms just the reverse, upon the same basis of his interpretation of Scripture. So that I can find no criterion here of what is sound or unsound. An individual again makes the same affirmations, because such positions accord or disagree with the teaching of the church. But how does he know what that teaching is? Others in the same church, hold quite the reverse as its teaching. He very boldly affirms such and such things to be "unsound" or "dangerous," because they do not agree with the opinions of that class of writers and interpreters whom he has chosen to select as "sound,"-as the truest expositors of the teaching of the church, and as his authorities. How does he know that he is correct in his judgment, and that quite another class may not be in the right? Has he read all the mass of Councils, and Fathers, and History? Others have done the same, 
and come to diametrically opposite conclusions. Has he not read them? In either case, it is his own judgment or predilection upon which he rests. His very view of what is "the Church," may not be admitted even by all within his own communion; and between the variety of private judgments, among "high," "low," "AngloCatholic," "Evangelical," "Presbyterian," "Greek," Roman," etc., by what possible criterion, but my own judgment after all, can I decide which is the true authority, or the true interpretation, or the Catholic tradition? These are evidently points apon which intuitive reason can give no reply, but which belong wholely to the decision of the understanding, according as the evidence and arguments presented may affect it. And, as the decisions upon these points are almost countlessly rarious,-are widely different and even opposite within the same communion,-I am foreed to the conclusion that either no absolute truth is attainable, or that it must be sought elsewhere, and that these points of endless dispute are consequently indifferent. Each disputant attempts to confirm and establish his point, - not by an appeal to the common sense of all christians, but by partial evidence, which is not admitted by the great body of christians as warranting any such conclusions as he seeks to prove. Now in lieu of these unsatisfactory and sceptical processes, I look to the universal consciousness of christians, just as to the universal common sense of mankind. To discover what is absolute truth for all men, I must seek what approves itself to the common sense of humanity. To discover what is absolute christian truth, I must equally seek what approves itself to the common consciousness of christianized humanity. The objection of indefiniteness urged against this principle, springs from the fact that men find it easier to rest upon their own judgments, than to correct their views by the general sense and experience of others, as often it requires great patience and laborious analysis, and much candor, to separate what is general, material and absolute, from what is particular, formal and fluctuating; while it is much more agreeable to the mass of mankind to expend the labor of investigation upon what will give them 
formal, tangible dogma, than upon what will lead them to abstract, universal principles. But whatever indefiniteness may seem to belong to the absolute facts of the universal christian consciousness, it fades into insignificancy when compared with the tremendous array of conflicting systems and dogmas, between which the understanding must decide, if absolute truth is to be discovered there. The objection as to the impracticability of applying the principle, is more apparent than real; because every ehristian man knows that there is something common to all christians, which makes them christians, despite all dogmatic differences. If christian consciousness, christian life, christian experience, be not a mere delusion, then it certainly is not more impracticable to diseover what are its universal elements, and what truth does approve itself to the universal common sense or consciousness of christianized humanity, than to discover which system is the true one, amidst the vast variety presented in differing communities. And there is this immense difference; that while a particular formal system can only be problematically true, as representing the ideas of a limited portion of ehristian humanity,what is found actuated in the consciousness of all,- - approving itself to the christian reason and necessities of all,-even amidst every mutual hostility and difference, must be absolutely true, if christianity itself be true at all. If, then, it is difficult to discover this absolute truth, yet must it exist, if christianity be from God; and, in view of it, both private judgment and tradition, find their appropriate place and true value, being employed, not to establish some particular system as the very body of christian truth, but to discover what, beneath all form and dogma, in every age and circumstance, has been and is the absolute truth, universally approving itself as such to the christian consciousness, - which all in connection with that consciousness recognize through the christian "common sense," and which affords a criterion and ground of certitude, such as no ehristian can doubt.

There is one view of this subject which claims a further notice, both because it is supported by men of great ability, integrity, learn- 
ing and earnestness, as well as because it is fatal to every thing like freedom of intellect and conscience, and must, therefore, be deeply injurious to christianity, should it be enforced by any religious community.

Starting from the circumscribed view, that the present danger to the church lies only between the tendencies to a corrupt form of christianity on one hand, and on the other, to a widening and loosening of the specific dogmas and symbolic formularies of the individual community, so as to fraternize upon the general platform of existing Protestantism, and entirely orerlooking the pressing and stern fact, that the true and all-absorbing danger is really in the ominous contest which is drawing near, for the very existence of christianity itself,- of morals, - of belief in a personal God,-a contest which will render utterly insignificant all disputes between different christian communities, and will swallow up the small squabbles about "Catholicity" and "Evangelicalism," and "High" and "Low," and "Church" and "Schism," and "Calrinism" and "Arminianism," and similar disputes, (all based upon the antecedent recognition of ehristianity and Scripture as Divine,) in the vast contest for any revelation whatever, the riew of theology alluded to, confines itself to the mere changes threatened in the Church itself. Opposing justly the notion of unbridled liberty, which the innorators on either hand, contemplated by the adrocates of the view we are regarding, claim, and which is a mere substitution of their own spiritual despotism for the restraints from which they wish to be free; the maintainers of the view discussed, urge that there must be a limit somewhere,-that both diverging classes of innorators, recognize that limit to be the will of God ; and, hence, the point is pressed, how they can know that will? If by a revelation to themselves, it is for themselves only, unless they can attest by miracles and signs their inspired character, when they come to actions which affect their relations to others. If that will is known by a general revelation, of which the innorators are only sharers with others, then that revelation must be interpreted by competent authority to be a rule for the whole church, because the 
individual stands not alone, but is associated in relations in the Church of Christ, which affect the whole life and being, in all their variety and duration.

So far, the maintainers of the view considered, stand upon solid and undeniable ground; but here an assumption comes in, which vitiates their whole subsequent reasoning. It is the confusion, ever made in all ex parte arguments upon the subject, between "society" and " $a$ society,"-"societas" and "sodalitas." The christian life introduced into the human consciousness by its Divine author, was the vital element whence christian fellowship, and hence christian society ("societas") grew. It actuated itself objectively in the organization of churches, as the social element of human society, actuated itself in nations. And as nationality is subordinated to the humanity in which it is rooted, so is the particular church to the christianity which is its necessary basis. But the moment that christianity is assumed to be coincident with " $a$ society" ("sodalitas,") then it becomes determined by the form and characteristics of the society; and, hence it logically follows, that the normal form and constitution of that society being determined, (as it is supposed to have been originally imposed to constitute $a$ society, ) christianity must be sought and recognized where the form of the church exists, although the vital life be dead, and must be virtually ignored, where the form is wanting, although the christian life be clearly developed. Hence, the first assumption being granted that the church is not a natural growth outward from the subjective vital christian consciousness, but is a socicty whose form was given to, or imposed upon that consciousness, as the exponent of christianity established for it from without; then the whole reasoning of the ultra-advocates of church authority is logical and irresistible, and the opposition of the other party, who yet start from the same assumption as to the origin of the church is utterly futile.

Now it is assumed that the church is an organized society, and not christian society, developing itself in organic growths, like human society in rarious states. From this grand assumption, it is argued that each Branch Society of the Catholic Society of the Church, is 
the exponent of the Catholic Society, and, hence, the limiter of individual will and liberty, to each member of that particular branch. Now it is most true, that the Catholic Society is the guide of each individual, but the only manner in which it can be so, is by the universal christian consciousness propagated in humanity, and with which each christian is brought into vital connection, by the fact of his becoming through his spiritual consciousness a partaker of the christian life. But the maintainers of the view discussed, assuming the nature of the church to be what they affirm, hold that its rule, as the expressed will of God, binds the individual conscience and judgment, as soon as these have settled what is that rule in its primal form. Hence, every one must doubt whether it be not a great peril to dissent upon his private judgment from the particular rule under which he lives. A principle which is a perfectly legitimate consequence from the premises whence it is drawn, but which must be good for the Romanist, the Presbyterian, the Episcopalian, alike; and, hence, directly militates against the theory of the church, which the theologians we have in riew contend for, or else leads one to suspect that the differences are unessential, or that absolute truth on the subject is unattainable. For it is argued by the theologians referred to, that while the primary decision must be made by the individual judgment, enlightened by conscience; yet, the decision once made, it is imperative ; and should he then find his judgment come in conflict with the authority, it is in a new relation, as member of the society of the church, and thus he may peril his eternal hopes, by following the dissent of his judgment from the rule of the society, which is for him the exponent of the will of God. This necessarily obliges him to look to the authority whence he may learn what he is to believe and hold, as the delivered will of God. In other words, the teaching of the society is his absolute guide. But as its authorized teachers must teach not what they believe, because it is what they believe, but because it is what the church teaches; they thus actually become the church for teaching; it teaches them; they are bound to teach only its teachings; and thus every individual member of the 
society is shut up to his Parish Clergyman as the authority of the church, the exponent of the will of God for him. The obvious absurdity, the superstition, the infidelity, to which such a conclusion gives rise, invalidate the premises from which it is rigidly deduced. But the teachers themselves, bound as they are to deliver only the teaching of the church, how are they to certify themselves, that they are not perilously deviating from, or modifying it? If the church was an organized society, with a given deposite of interpretation of the Scriptures, then whatever difficulty may envelope the question, as to which existing society is that society,-whatever inextricable confusion may complicate the questions as to the decision, whereby the whole matter must rest, after all, upon the individual judgment; yet, having bound up oneself by the decision, and committed all to one society,-then the teaching of that society as to what was the given deposite, must be settled for himself by the teacher. To him that teaching presents itself in the formularies of the church; but how are these to be interpreted? Undoubtedly they must have a fixed and positive sense, and therefore can not be subjected to the fluctuating opinion of the currently received sense of the day, or of the imposer, unless the church be the imposer, and then her sense is the very matter at issue. The only tangible ground is, that they must be interpreted by the known intention and sense of the compiler or composer. So that after all, here is a complicated question of historical criticism, upon which we actually find the teachers in the same church differing. Who is to decide between them? But there is this fatal consequence to such a view as we have been considering; that besides, in the last step, ever resting the whole matter upon the individual judgment, and thus inducing scepticism as to the possibility of any absolute certainty; besides, this pressing of church authority being the most ultra form of the doctrine of private judgment, inasmuch as it erects an authority upon the decision of that judgment, which crushes all other individual judgments ; it also would bind up the intellect, conscience and progress of every age to the intention and sense of certain individuals centuries ago, upon the assumption 
that they, by exercise of their private judgments, settled forever and absolutely the fixed catholic truth; although by far the greater part of christendom, do not allow that those men did wholely sift out, or perfectly retain, or justly express, the catholic truth which was intended for every age and circumstance. The truth of God,the whole progress of biblical interpretation and of scientific Divinity, as the accurate and just exponent, or logical form of the truth, can not be thus shut up to the private judgments of men of a past age, without danger to intellectual culture and spiritual growth. There is a mighty store-house of christian food in the theological writings of the deep and great spirits of past time. But it is food for the nourishment of the spiritual life, not for binding up thought to dogmatic channels. The Divine element introduced into the human consciousness by the Divine Saviour of mankind, by the law of its own vitality actuated itself in the organic growth of christian society. It is truly a life in humanity, of which Christ is the root, and every christian a branch who, can only live in Him : And not in a particular society, but in the universal christian consciousness itself, is to be sought the rule of every christian society,-the only true sense of the rule "what always, everywhere, and by all, was" and is realized as approving itself to the common sense of the church. So applicable here is the "Postscript" to Mr. Morell's Fourth Lecture, (on the Principle of Common Sense,) in his remarkable "Lectures on the Philosophical Tendencies of the Age," that we feel no apology to be necessary for quoting it entire.

"The most important application of the principles advocated in this Lecture, is that which employs them to find a ground of certitude in the domain of religious truth. If there be one thing, for which, more than any other, the age we live in is longing and struggling, it is some intelligible expression upon this head. The profession of the full liberty of private judgment, openly made by most Protestant communions, has long since been seen and felt, by the thoughtful of all parties, to be little better than a delusion. When fully carried out, it has led almost universally to this decided alter- 
native- 'Either we ought to welcome every honest mind, however wild and extravagant its individual theories and speculations, as having an equal chance of being right with ourselves, and equally eligible to all the intimacy of christian fellowship; or, giving up the principle of private judgment altogether, we must cling fast to the living voice of tradition where best it may be heard.'

"The last ten years have seen many earnest minds accept the latter side of the alternative, as a last resource against the strides of rationalism, which with logical foresight, they perceived would soon overtake them. It is very easy and very natural for Protestant churches to wail and lament over the numerous conversions to Popery, of which we oft-times hear; but it were far better if, instead of bandying reproaches, or shedding tears over apostasy, they were to gird themselves vigorously to the work of examining their own principles, and see how far their indefiniteness may be responsible for such calamities. Suppose an inquiring mind, unable, as the very result of its deep moral and religious earnestness, to take every thing upon mere trust, to come humbly and sincerely with the question, 'Where am I to repose confidence, with respect to the validity of my religious belief?' What answer, I ask, does he receive from almost every Protestant community? The first answer is, 'Search the Scriptures.' Accordingly, he does search them. With eagerness, with industry, with prayer, he employs every aid which comes to his hands; and the result, in all probability is, that he evolves many sentiments differing materially from the system of truth accepted by the Church to which he belongs. I say, in all probability, because perfect agreement with it, when there are so many conflicting opinions built upon these same data, could hardly result from any thing else than a traditionary bias. This result, then, he brings to the church, and presents it as the sincere product of their own principle of private judgment. But how is he received? with joy? with satisfaction? with approbation, as an earnest lover of truth, and a patient seeker for it? Nothing less. He was sent to the Bible, not to seek truth, but to find in it their own distinctive 
system ; and the error of not finding it there complete, is unpardonable. The error, as we think, was really in the instructors, who failed to give any intelligible principle of research; and the mournful result is, that moral earnestness for truth, which as a virtue, is infinitely higher than blind submission to authority, is condemned and punished, instead of the false intellectual principle, which the inquirer had honestly applied, being kindly corrected. Such are the inevitable evils arising from confounding the moral and intellectual meaning, attached to the principle of private judgment.

"Driven away, therefore, from the full exercise of private judgment, and accused of nurturing heresy (God knows it is honesty) in his bosom, where does he next look for satisfaction? The only directory which most Protestant churches give, is to the fathers and founders of their own sereral denominations. But it naturally occurs, Is the opinion of one set of founders any better than another? Is it not better to go beyond them all, and put trust in the earlier fathers of the church? Certainly, if human authority is to be the guide, the nearer we go to the well-spring of apostolic teaching the better. Accordingly, the inquiring mind is driven onwards, by want of any definite principle in his Protestant advisers, into the arms of absolute authority, or at least, of ecclesiastical tradition. This process is not a mere imaginary case. It is a case I have witnessed in more instances than one, and that, too, in connection with minds deeply pious and conscientious; but, alas ! too logical to be satisfied with a superficial and imperfect response to their soul's inmost yearnings and necessities. I say, therefore, that our Protestantism has this duty imcumbent upon it, either to allow of private judgment to the uttermost, or to think out for itself some intelligible principle, by which the rationalistic results of individualism are to be curbed and prevented.

"Such a principle, as regards philosophical truth, we have endeavored to derelope in the preceding lecture; the same principle, as regards religious truth, has yet to be brought into action, as affording some intelligible reply to the inquiring spirit of the age. For 
ourselves, we have the deepest conviction that the doctrine of intuition, applied to the development of christianity, gives us a hold upon something generic, catholic, objectively real, to which the individual reason, or, as it is often termed, the private judgment, must necessarily bow. As regards, indeed, our logical consciousness, and consequently, as regards the formal statements of our theology, the individual principle is not to be repelled-and Protestantism has ever felt itself strong in this position; yet, with all the strength of this position, it has ever shrunk from the consequences of individualism, and adrocated tacitly some kind of common 'consensus,' in order to put a drag upon its operations. It has, in fact, been feeling after the principle of a generic, and even a catholic christian consciousness, though, for want of the true philosophy of intuition, it has not been able fully to realize it. With the aid of this philosophy, we are now able to show the via media between ultra-individualism, as involved in the doctrine of private judgment, and traditionary authority, as residing in an external and living infallibility.

"Let it be admitted that the objective data of christian truth are divinely revealed, the question next is as to their interpretation. Now if it be allowed that christianity has to overcome all antagonistic evils, and, in the process of its historical development, to come forth clear and brilliant as the light of day, it follows from this, that the living spirit, the whole religious conscionsness of humanity in its providential growth, acted on by the divinely inspired christian element, is the real expounder and interpreter of the full truth and meaning of Christ's holy religion.

"This may involve many individual paradoxes in its course; but such is the case with the development of every great idea, which ever separates itself into opposite poles, in order to meet again in some higher unity. This is the very life of its being, the rhythm of its history - the steps by which it marches forward to its great and ultimate realization.

"To trace these steps, we must study the history of the past, and see the thread of catholic truth weaving itself with a silvery bright- 
ness through all the wanderings of those speculations to which the christian consciousness of the world has given rise. And then, just as we track the midway course of the vessel, which makes its way on either tack against the breeze, so shall we see that the church of the first-born has ever held on her way against heresy, even when apparently deviating from the more direct pathway.

"Here, then, we shall find a guide by which to direct the efforts of our logical understanding. Imbued with the vital spirit of christianity, the pride of reason will receive its due check; just for this cause, that it is made to feel its incapacity to furnish any real material of holy thought, and that its efforts are confined to the recasting, clearing, and bringing into scientific form, the spiritual life which flows direct from God, and permeates, by his divine guidance, the religious consciousness of mankind at large.

"On this theme we would fain enlarge, but we promise the reader a more full and formal statement of it, together with many kindred topics before very long.* We merely throw out these hints as pioneers of what is to follow. To the men who accuse us of "subtlety" we reply, read and think for yourselves. Far are we from wishing to hide a single thought from the deepest recesses of our bosom. $W e$, at least, conceal no secret misgivings, under the cloak of zealous orthodoxy; we tremble not for the cause of truth, from whatever quarter assailed. But still assuredly, our spirit is not one of subtlety or deceit; we have no faith in any thing but moral honesty and christian candour; and instead of insinuating one thing and meaning another, our whole reliance is in the 'manifestation of the truth to every man's conscience as in the sight of God.' "

* This promise is fulfilled in the author's "Philosophy of Religion." 


\section{APPENDIX C.}

\section{NOTE TO PAGE 205.}

IF the authority of Christ as a plenary-inspired Delegate from God (and much more as the Divine Son of God,) be conceded, then it is a sound argument, that if he sanctioned the Pentateuch (as we now possess it,) as an inspired Book, and as the work of Moses, it must certainly be so; or if it can be proved not to be, and Christ was mistaken in that respect, then he could not have been inspired in the most plenary manner, and his prophetic claims must be adjusted among all other prophets accordingly, since it would be futile to argue his divinity further. Moreover, if Christ can be proved to have been mistaken respecting the inspiration and authorship of the Pentateuch, this would not prove that he was not the greatest of all God's Delegates, and had not been sent by God to introduce the greatest and most important revelation ever made to man. But, on the other hand, if Christ did not express an opinion respecting the Pentateuch; or if he so expressed an opinion as to imply that it was not inspired or written by Moses; or if he only alluded to it as a received sacred book of the Jews, without expressing any opinion as to whether it was inspired or not, or by whom written; or if he implied that the book contained elements of a revelation to the Jews, but that it was of no importance who wrote it; or if he referred to it for the sake only of an argumentum ad hominem, and in view of his own revelation, did not deem it important to express any opinion about the Pentateuch; in any of these cases, it is evident that the Pentateuch has nothing to do with christianity, or with the claims and character of Christ. If Christ was mistaken (an impossible case,) with regard to the Pentateuch, the sole point affected would be his absolute Divinity; and still even the Arianism nearest approaching to Athanasianism might be fully held. If Christ referred to the Pentateuch, according to any other of the suppositions made above, then not even 
the question of his absolute Divinity is touched. Those who believe in this, do not regard it as touched by Christ's declarations of subjection to the Father, and of the ignorance of even the Son respecting a certain hour, with which, nevertheless, the Son himself is intimately concerned, because these things are attributed not to his Divinity, but to his humanity. In the same manner, it might be supposed, that as a man, Christ was ignorant of science and historical criticism, and might not have known whether Moses wrote the Pentateuch or not, since it was not important for his mission to know it, and since in his human nature, so far as his great redemptive work was not involved, he felt and believed as a pious Jew. And if it could be proved on one hand (as it assuredly can be,) that Christ was Divine, and on the other that the Pentateuch is not genuine or authentic, then some method would undoubtedly be resorted to, and clearly seen, for proving that the two points are not involved in each other. No christian man would give up christianity, because the Pentateuch was given up. It was once said that the Scriptures undeniably made statements as clear as language could speak, contrary to alleged scientific facts, and that if the facts were proved, the contradiction would destroy Scripture. The facts were proved, and then it was ingeniously discovered that the Scriptures could be interpreted quite in accordance with the facts. So if it ever should be proved that the Pentateuch was not written by Moses, and is a compilation of legends, or that the human race originated from many distinct pair; the sincere believers who now regard such positions as subversive of Scripture and christianity, will believe none the less, but will see at once the perfect ease with which Scripture can be reconciled with every result of science and historical research. How many interpretations have Astronomy and Geology taught, which à priori, it would never have been believed possible to elicit from Scripture. And if, for instance, it should be proved scientifically that the human race originated from many distinct pair, it would at once be seen, that as for geological truths, the first two verses of Genesis have been separated from the succeeding,- -as for astronomical, the 14th 
verse of the 1st chapter of the same book, has been considered as expressing the appearance to a spectator, from whose range of vision the mists and thick vapors are rolled away,-and as some parts are regarded as proleptic, all intervening and subsequent parts as taking up the interrupted narrative; so the first chapter would be interpreted as relating the creation of males and females indefinitely,-the second as giving account of a special race; the words, "made of one blood all nations,"* would be interpreted of "one nature;" the mingling of all races would account for the depravity of all, (if any one fountain be poisoned, its waters will corrupt those of all the other fountains which, with it, make up a stream,) and the community of moral nature, the Unity of Humanity, (possessing Reason, Conscience, and qualities abore the brutes,) would be found compatible with different independent pair; just as the unity or characteristic stamp of brute nature, as distinguished from human nature, is compatible with the distribution of that brute nature among many originally different species. In short, the canon would be recognized that Scripture was designed for conveying moral and religious truth; and that it never intends to deliver any scientific fact; hence, that where it is judged to speak decidedly on any point open to scientific investigation, it is misjudged, for it declares nothing positive upon such subjects, and hence can not clash with any results at which science may arrive. Or, the inspiration of Scripture will be regarded as entirely confined to supersensuous truths of practical bearing upon the spiritual nature of man, and hence as not affected by error upon any points in which such truths are not involved.

Now, as to the Pentateuch being sanctioned by Christ, it can only be determined by an examination of the places in the Gospels, where Christ is represented as alluding to the Pentateuch. This is quite a distinct question from the character of the Pentateuch itself; for whatever sound criticism may determine respecting that book, it will ever be regarded as containing the most venerable, important, and interesting traditions of the human race, and it will ever be 
ranked among the canonical books, which are filled with ideas and religious truths, that could only have emanated from inspiration.

The following are the places in the Gospels, in which Christ is supposed to be represented as referring to the Pentateuch.* The first four or five places are in St. Matthew's account of the temptation, (chap. 4.) and in the parallel account in St. Luke, (chap. 4.) In these places, our Saviour evidently employs the passages he quotes, in the manner of an argumentum ad hominum, by repelling Satan's temptations, based upon quotations from the Old Testament, with quotations from the same authority to which the tempter had appealed. Our Lord refers to the words, which he quotes merely by the expression "it is written;" and hence nothing can be argued, as to the authorship of the Pentateuch, from these references, nor any thing further, than that the Saviour regarded the words which he quoted, as true in the religious sense in which he used them.

Next, in the 12th chapter of St. Matthew, (v. 5,) our Lord refers to "the law," merely as an argumentum ad hominem, addressed to the Pharisees; and not only does he not express any opinion respecting " the law," but it is not even certain from this passage, that the term refers to the Pentateuch, as we now have it; while his claim to be superior in authority to the law itself, rendered it unnecessary for him to pronounce any opinion respecting it.

In the 19th of St. Matthew, all which can be deduced from our Lord's reference, is, that he regarded the account of the creation of male and female, as true, and that he admitted Moses to have been a real historical lawgiver, who granted a permission, (on account of the stubbornness of the Jews,) which Christ implies that he himself had authority to abrogate. It may be inferred, that as Christ represents Moses making a concession to Jewish stubbornness, which was not strictly in accordance with the original design, in regard to the relation of man and wife, and yet does not reprehend Moses, he

\footnotetext{
* In the "Sermon on the Mount," the expressions "them of old time:" and "it hath been said," are not proved to have reference at all to the Pentateuch.
} 
thus sanctions the idea that Moses would only have ventured to do so by divine permission; and thus ratifies the belief in the inspired mission of the great lawgiver. No doubt this is true. But the recognition of Moses as an inspired Prophet, does not involve any opinion respecting the Pentateuch. It may contain some of his own composition; it may record what was traditionally known of the great Prophet; it may be all the work of his hand. On these points, our Saviour says nothing in the passage before us. And in this same chapter of St. Matthew, where Jesus refers to " the commandments," and recites a compend of the moral law from "the ten commandments," it is evident, that it is the same as if he had referred to the natural moral law; and he implies nothing as to the Pentateuch or its author, in thus quoting that law in its most familiar embodiment. Parallel passage, St. Luke, x. 26.

Again, in the $22 \mathrm{~d}$ chapter of St. Matthew, our Lord quotes a declaration as God's, and also sanctions a command of "the law ;" neither of which facts inform us respecting the authorship of the Pentateuch, nor whether it may not contain much besides the original records of Moses' mission, and of an ancient revelation. Our Lord, with a higher authority than Moses, introduced a new dispensation, destined to establish itself by its own vitality, and therefore was under no necessity of formally abrogating the Levitical institutions, or of expressing an opinion respecting the Pentateuch.

In the 12th chapter of St. Mark, (v. 26,) the expression, "book of Moses," employed by our Lord, is too vague to warrant any positive inference, since it may mean the book written by Moses, or the book containing the account of Moses ; and it is no expression of opinion respecting the Pentateuch, being parallel with the passage just referred to in the $22 \mathrm{~d}$ of St. Matthew, and implying no more than that "the book" contained records respecting the mission of Moses. Another parallel account of the same saying of Christ, is in St. Luke c. xx. v. 37.

In St. John, chapter 5, verse 46-7, our Lord is represented as declaring that Moses "wrote," and implying that "his writings" were 
in the hands of the Jews. Not to discuss the point of verbal criticism, whether "wrote" is strictly correct, or whether it is more than "spake,"-it is clear that the scope and intention of our Saviour's words was, that if the Jews believed the records which they possessessed, of the character and sayings of Moses, they would believe him, of whom there was recorded and reliable tradition, that Moses prophesied; and it is also evident that our Lord did not intend in these words to express an opinion respecting the Pentateuch, but to apply to the Jews an argument based upon what they themselves admitted as authority; and which argument would be equally good if Moses was author only of certain documents in the Pentateuch, or even if only his words were recorded in the writings, which contained an account of his mission.

In the 27 th verse of the 24 th chapter of St. Luke, nothing more is implied than that there were prophecies of Moses recorded.

No believer in the Scriptures can doubt that Moses was an inspired Delegate of God, and that the Pentateuch contains an account of his life ; but it appears to us evident that our Saviour pronounced no opinion which can interfere with the freest critical research as to the age and authorship of the Pentateuch, and the amount of uninspired matter which it may contain. No critical results on these points can affect the glorious redemption of Christ. When a man truly is convinced of sin, experiences the godly motions of the Holy Spirit, leading him to repentence and faith, and finds his hope and comfort in Jesus Christ, little can any conclusions respecting the Pentateuch affect his peace and religious life. The humble christian who is truly a "new creature," having his "life hid with Christ in God," will possess an evidence of his faith not resting upon, nor to be shaken by, historical criticism; and he will truly appreciate the priceless religious value of the Scriptures, in prosperity and adversity, in affliction and in the hour of death. 
$F=x^{2}=t$

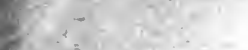

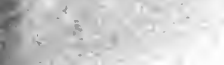

13.

$F=k=k=\ldots$

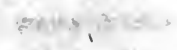

Nise: $=2 x$

Fi: :

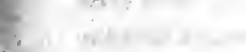

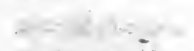

helis $\because$

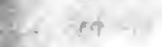

i -

$e^{\prime}+x$

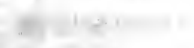

ax-met +4

$.17+2$

*

$-4 x^{2}-64=$

$\sin x=$

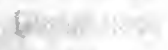

$\hat{\sigma}^{2} \psi$

and

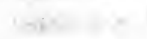


1 
THIS BOOK IS DUE ON THE IAST DATE STAMPED BEIOW

\section{AN INITIAL FINE OF 25 CENTS} WILL BE ASSESSED FOR FAILURE TO RETURN THIS BOOK ON THE DATE DUE. THE PENALTY WILL INCREASE TO SO CENTS ON THE FOURTH DAY AND TO $\$ 1.00$ ON THE SEVENTH DAY !) OVERDUE.

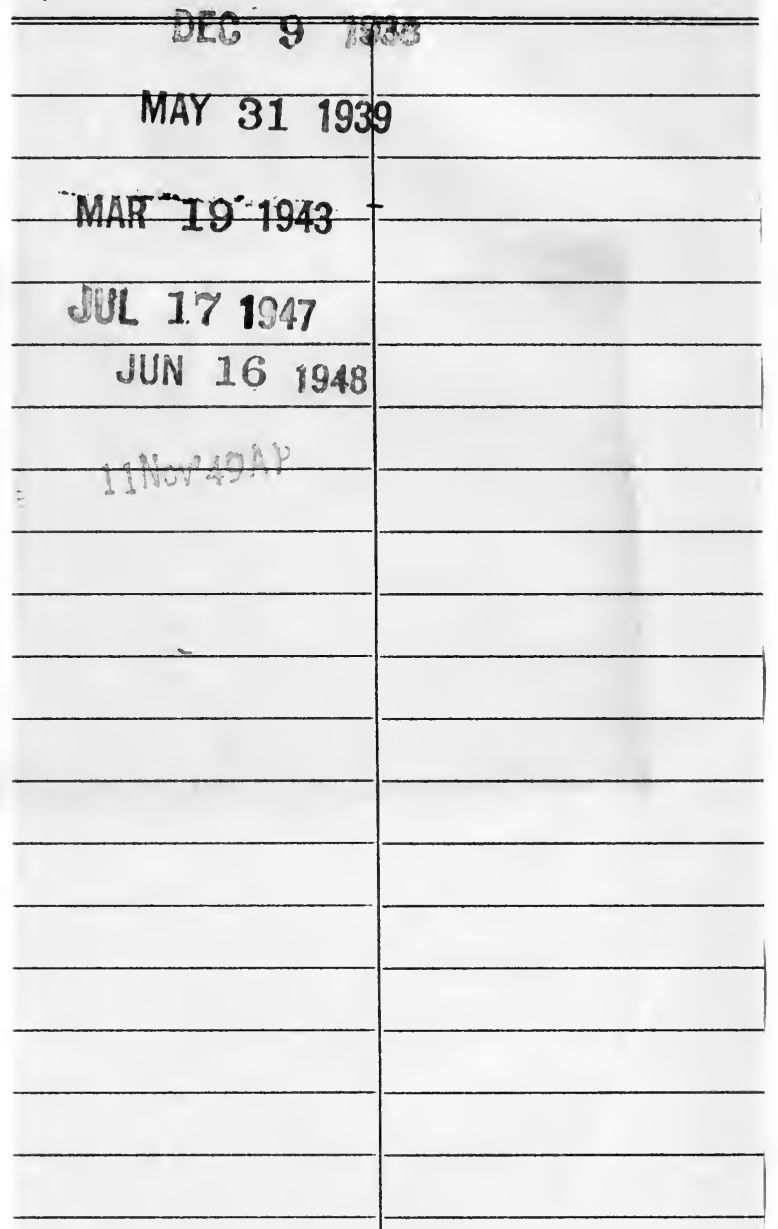




\section{YC 40916}

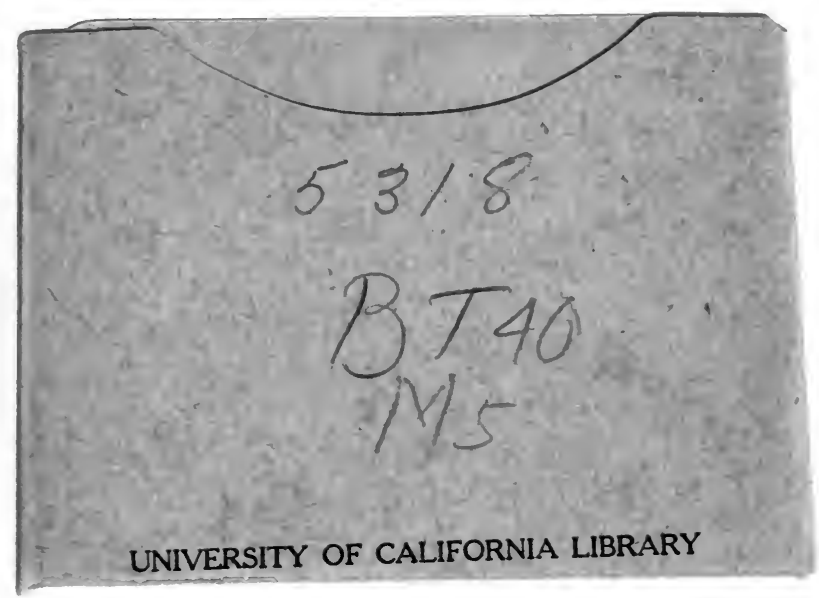


